\title{
DESEMPENHOS OPERACIONAL E ECONÔMICO DE UMA COLHEDORA EM CANA CRUA
}

\author{
Moizéis Silva Nery \\ Engenheiro Agrônomo \\ Orientador: Prof. Dr. TOMAZ CAETANO CANNAVAM RIPOLI \\ Dissertação apresentada à Escola Superior de \\ Agricultura "Luiz de Queiroz", Universidade \\ de São Paulo, para obtenção do título de \\ Mestre em Agronomia, Área de \\ Concentração: Máquinas Agrícolas
}

PIRACICABA

Estado de São Paulo - Brasil

Abril - 2000 


\title{
Dados Internacionais de Catalogação na Publicação (CIP) DIVISÃO DE BIBLIOTECA E DOCUMENTAÇÃO - Campus "Luiz de Queiroz"/USP
}

\author{
Nery, Moizéis Silva \\ Desempenhos operacional e econômico de uma colhedora em cana crua / Moizéis \\ Silva Nery. - - Piracicaba, 2000. \\ 108 p. : il. \\ Dissertação (mestrado) - Escola Superior de Agricuitura Luiz de Queiroz, 2000. \\ Bibliografia. \\ 1. Cana-de-açúcar 2. Colhedora 3. Colheita mecânica 4. Desempenho operacional \\ I. Titulo
}

CDD 633.61 


\section{DEDICATÓRIA}

A minha esposa Goreth pelo apoio, carinho, afeto, compreensão sempre dispensados e ao meu filho Renê Gibran

DEDICO.

A minha mãe Geny, ao meu pai Ivan e aos meus irmãos

OFEREÇO. 


\section{AGRADECIMENTOS}

A Deus de infinita bondade e misericórdia.

Ao prof. Dr. Tomaz Caetano Ripoli pela orientação, incentivo, amizade, confiança e liberdade depositada em mim na elaboração deste estudo.

A Universidade Estadual do Sudoeste da Bahia, por ter a qualificação de seus profissionais como um instrumento fundamental e necessário para o pleno desenvolvimento das atividades docentes.

Ao Departamento de Tecnologia Rural e Animal (DTRA) pela liberação em tempo integral durante todo o curso de mestrado.

A CAPES-PICDT pela concessão da bolsa de estudos.

Aos professores do Departamento de Engenharia Rural ESALQ/USP pela condução do saber cientifico.

Aos professores Dr. Luiz Geraldo Mialhe e Dr. Luis Antonio Balastreire pelas sugestões e correções propostas.

Aos professores Walter Francisco Molina Júnior, Gil Miguel de Souza Câmara, aos engeneiros agrônomos Marco Lorenzzo Ripoli, Sacha Savietto e Paulo Mialhe, pela colaboração durante os ensaios de campo.

Aos funcionários do Departamento de Engenharia Rural ESALQ/USP pela atenção, amizade, simpatia, sempre dispensados.

A Usina da Barra e seus funcionários de campo pelo apoio e colaboração na pesquisa de campo.

Aos colegas da Pós-graduação: Sérgio Pereira, Sérgio Carvalho, Fernando, Danilo, Juan, Adriana, Guto, Moema, Alessandra, Ricardo Pinto, Ricardo Fernandes, Tachibana, Pedro, João, Barros, Heitor, Marli, Luciano, Bizut, pela amizade e bons momentos.

Aos amigos Wagner, Cristina, Flávio, Edmilson, Maurício, Raimundo Leite, Leandro Portz pelo companheirismo. 


\section{SUMÁRIO}

Página

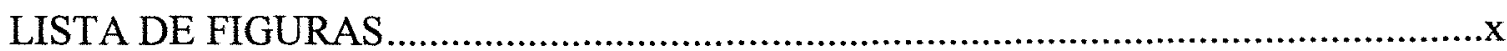

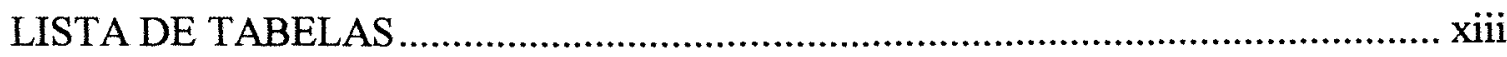

LISTA DE SIMBOLOS E ABREVIATURAS........................................................

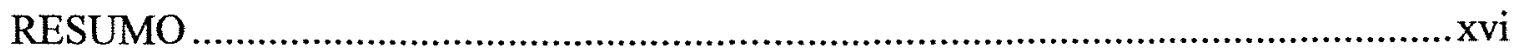

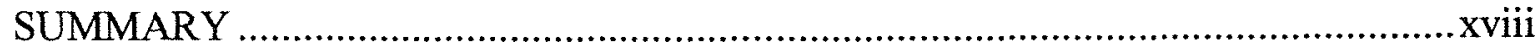

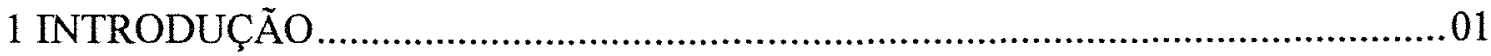

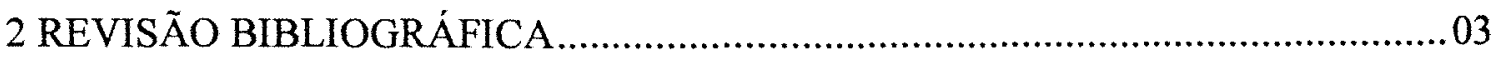

2.1 A cultura da cana-de-açúcar no Brasil .................................................................... 03

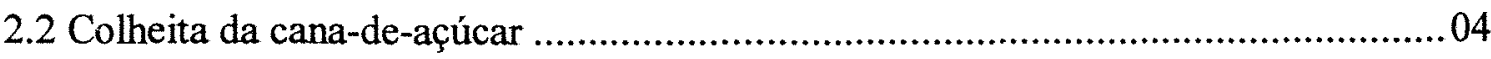

2.3 Colheita da cana-de-açúcar em cana queimada e em cana crua: implicações técnicas,

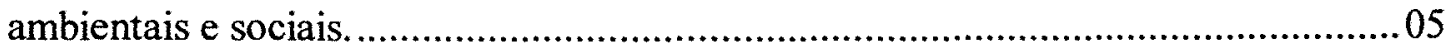

2.4 Colheita da cana-de-açúcar em cana crua: questões operacionais e econômicas.....09

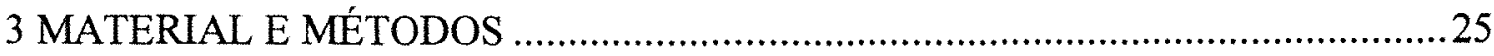

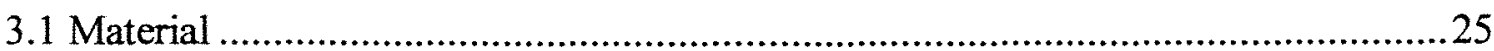

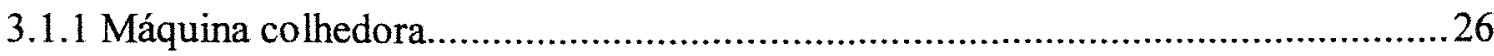

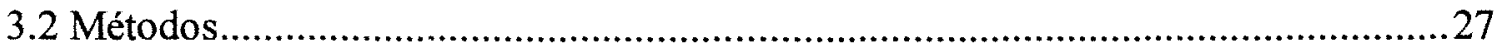

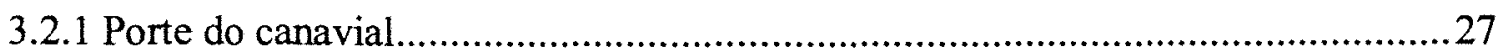

3.2.1.1 Densidade média dos colmos e matéria estranha vegetal...................................28

3.2.1.2 Comprimento médio dos colmos .................................................................... 31

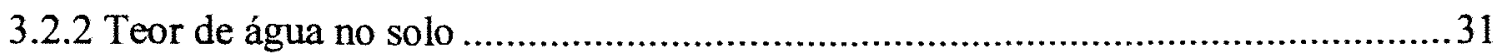

3.2.2.1 Granulometria do solo ................................................................................ 31

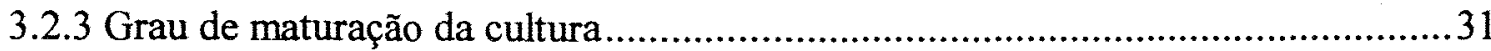

3.2.4 Desempenho operacional da colhedora........................................................... 31

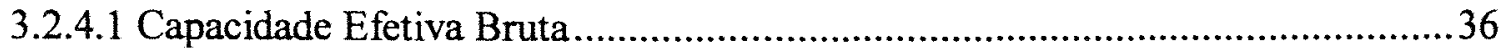

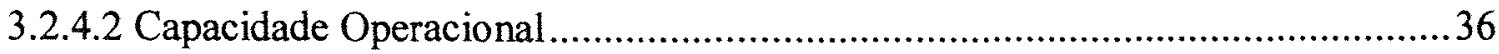




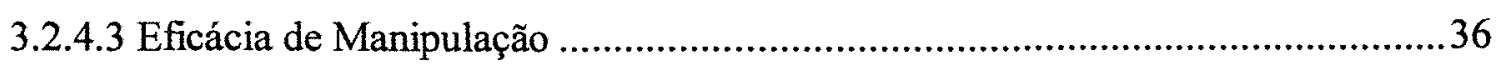

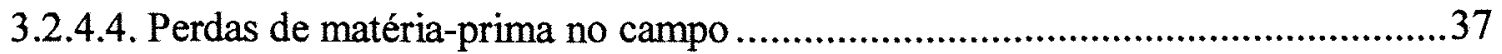

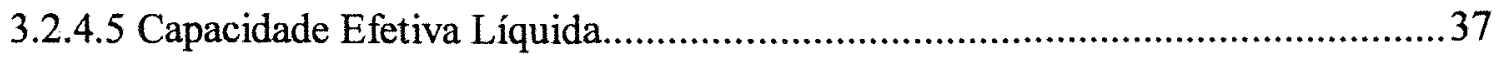

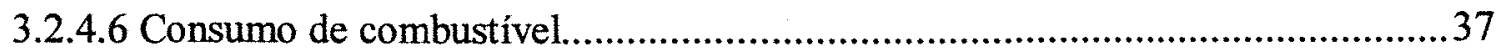

3.2.5 Índice de Matéria Estranha na matéria-prima...................................................38

3.2.6 Qualidade tecnológica da matéria-prima...............................................................39

3.2.7 Freqüência de comprimento dos rebolos.............................................................40

3.2.7.1 Índice de cisalhamento dos rebolos .............................................................40

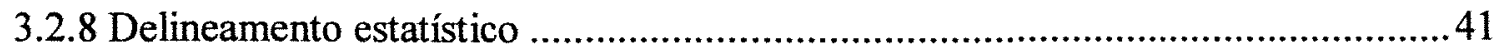

3.2.9 Análise do desempenho econômico .....................................................................41

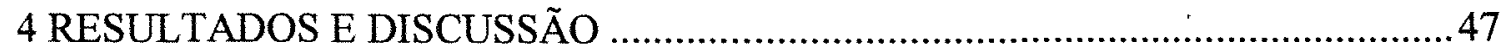

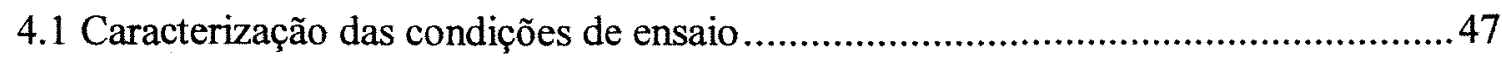

4.1.1 Densidade média dos colmos, ponteiros, folhas verdes e palha ............................47

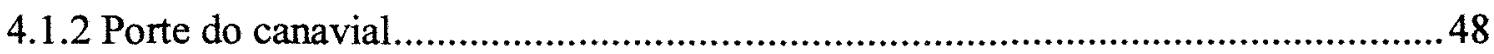

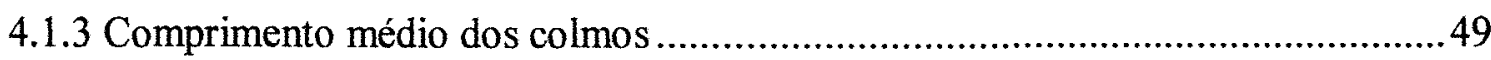

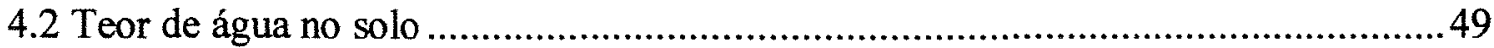

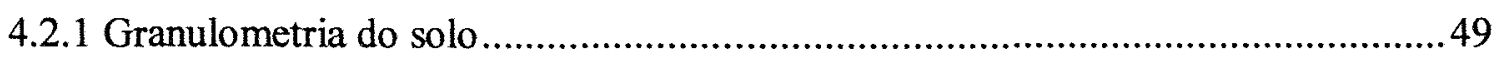

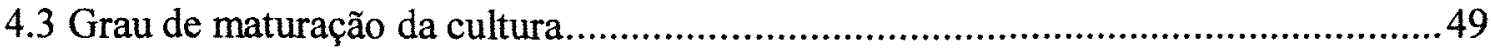

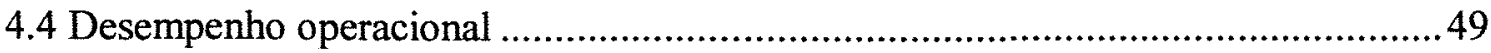

4.4.1 Velocidade efetiva de deslocamento..................................................................4

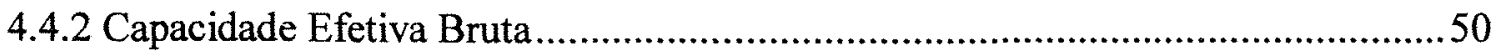

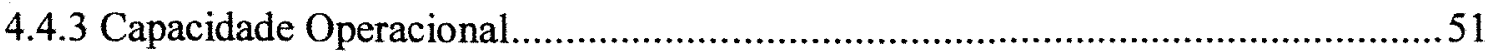

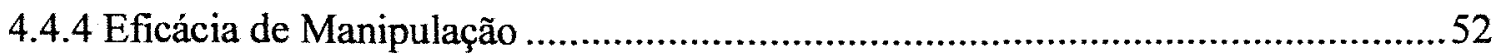

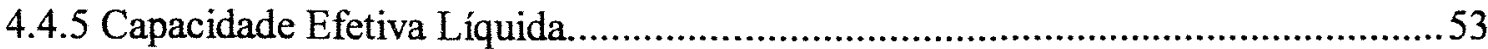

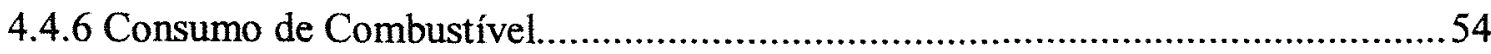

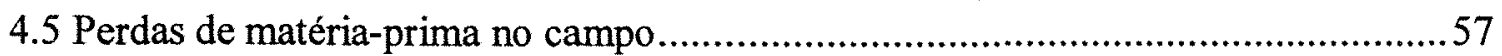

4.5.1 $\mathrm{Na}$ forma de colmos e frações de colmos............................................................57

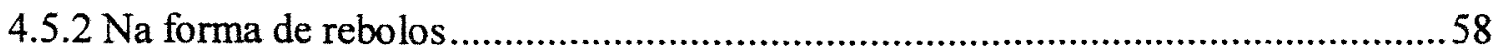

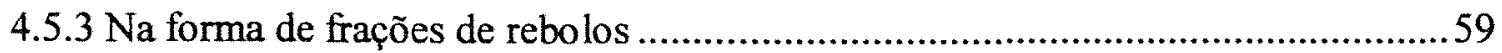

4.5.4 Na forma de frações de colmos na soqueira .......................................................6 


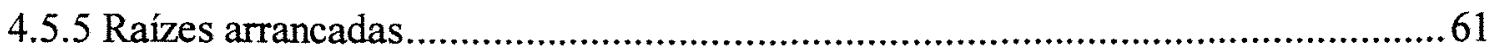

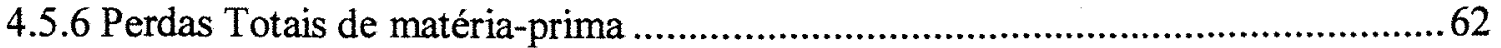

4.6 Análise matéria estranha no material colhido ........................................................63

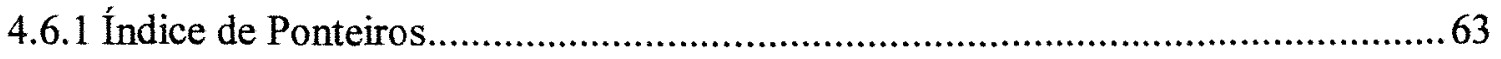

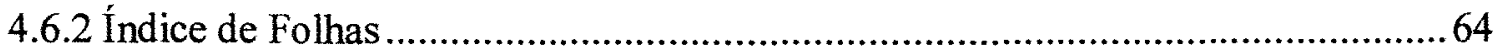

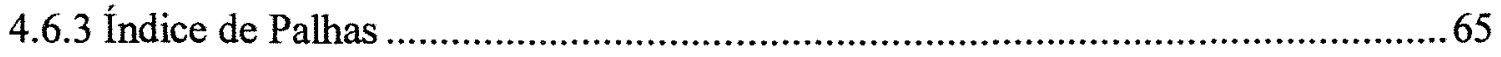

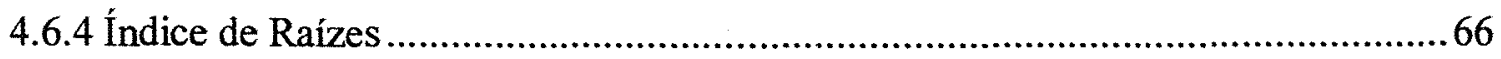

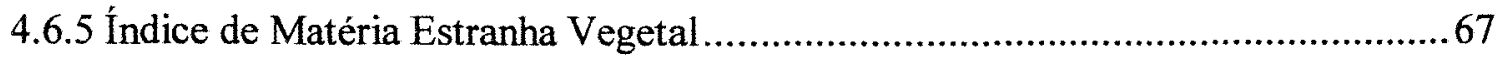

4.6.6 Índice de Matéria Estranha Mineral..................................................................68

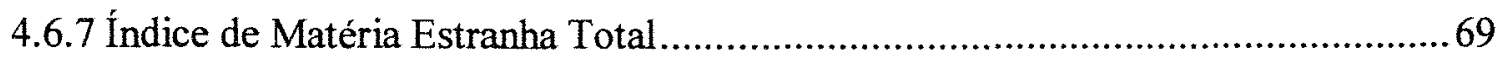

4.7 Qualidade tecnológica da matéria-prima............................................................ 71

4.8 Freqüência de comprimento dos rebolos............................................................

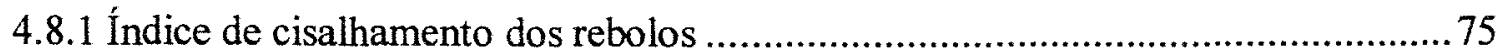

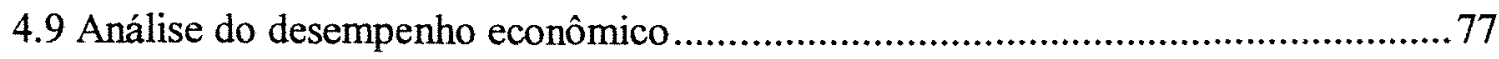

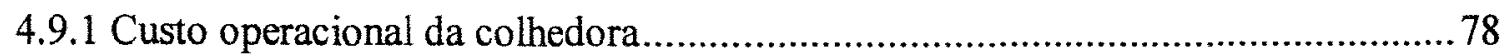

5 CONCLUSÕES

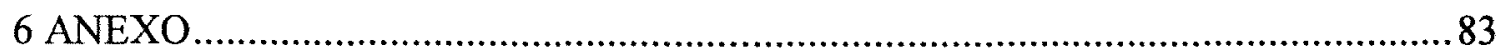

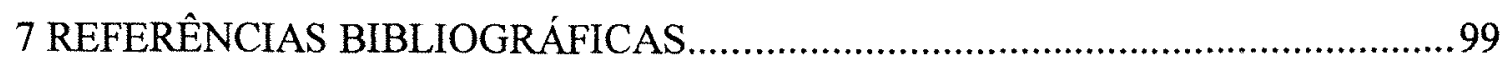




\section{LISTA DE FIGURAS}

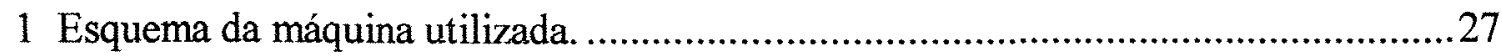

2 Gabarito utilizado para determinação do porte do canavial.....................................28

3 Utilização do gabarito para determinação do porte do canavial..................................29

4 Coleta de amostra para a caracterização do canavial. Separação de suas frações: colmos, folhas verdes, ponteiros e palhas. ............................................................... 30

5 Determinação ponderal dos colmos recolhidos em dada amostra..............................30

6 Máquina colhendo em uma fileira (repetição). ............................................................ 33

7 Resultado da ação do sistema de limpeza da colhedora. .............................................33

8 Esquema da área demarcada para as coletas de perdas de matéria-prima. ..................34

9 Recolhimento das perdas de matéria-prima em uma área de amostragem. ……........35

10 Separação da matéria-prima contida na massa vegetal em uma área de amostragem de perdas e as respectivas determinações ponderais.................................................35

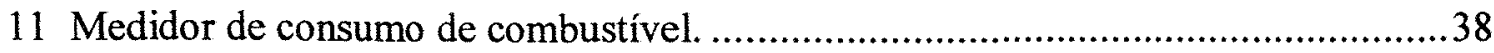

12 Amostra da variação do tamanho e da qualidade do cisalhamento dos rebolos....... 40

13 Resultados em peso e em percentual das frações constituintes do canavial. ............48

14 Resultado da caracterização do porte do canavial. ..................................................48

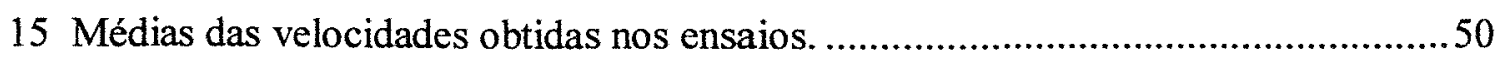

16 Capacidades Efetivas Brutas obtidas nas quatro velocidades estudadas. .................51

17 Resultados das Capacidades Operacionais nos quatro níveis de velocidades com

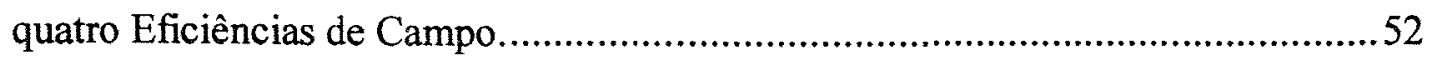

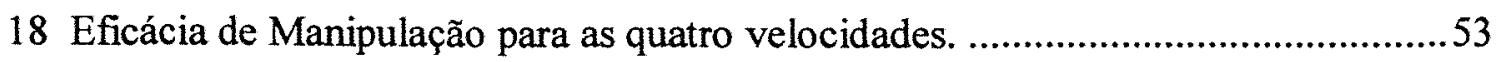

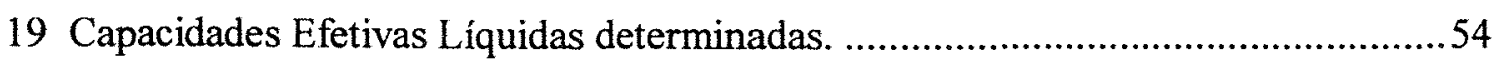

20 Consumo de combustível por matéria-prima colhida $\left(1 . t^{-1}\right)$, determinada para os 
quatro niveis de velocidades estudadas. 56

21 Consumo de combustível por hora de trabalho $\left(1 . \mathrm{h}^{-1}\right)$, determinada para os quatros níveis de velocidades estudadas. .56

22 Resultados das perdas de colmos e ou suas frações, nas velocidades estudadas. ....58

23 Resultados das perdas na forma de rebolos..................................................59

24 Resultados das perdas na forma de frações de rebolos .......................................60

25 Resultados das perdas na forma de frações de colmos na soqueira.......................61

26 Resultados da quantidade de raízes arrancadas pela máquina nas quatro velocidades estudadas. 62

27 Resultados das perdas de matéria prima para as velocidades estudadas. 63

28 Resultados da quantidade de ponteiros contidos na matéria-prima colhida. 64

29 Porcentagem de folhas verdes encontradas na matéria-prima colhida. 65

30 Quantidade de palhas encontrada na matéria-prima. 66

31 Percentuais de raízes encontradas na matéria-prima colhida. 67

32 Índice de Matéria Estranha Vegetal encontrada na matéria-prima colhida. 68

33 Índice de Matéria Estranha Mineral contida no produto colhido. 69

34 Índice de Matéria Estranha Total encontrada na matéria-prima. .70

35 Resultados de Brix (\%), Pol (\%) e Pureza (\%) do caldo nas quatro velocidade estudadas .72

36 Resultados de fibra (\%), Pol (\%) da cana e terra para as quatro velocidades estudadas. 72

37 Freqüência de comprimento dos rebolos obtidos na velocidade V3. 73

38 Frequêencia de comprimento dos rebolos obtidos na velocidade V4. 74

39 Freqüência de comprimento dos rebolos obtidos na velocidade V1. 74

40 Frequiência de comprimento dos rebolos obtidos na velocidade V2. 75

41 Porcentagem das características dos cisalhamentos dos rebolos na velocidade V1.76

42 Características dos cisalhamentos dos rebolos em (\%) na velocidade V3..............76

43 Características dos cisalhamentos dos rebolos em (\%) na velocidade V2 .............76

44 Características dos cisalhamentos dos rebolos em (\%) na velocidade V4 ..............77

45 Custos anuais com peças de reposição e filtros em sete anos de uso, segundo dados 


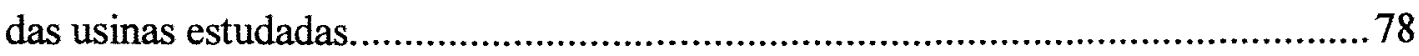

46 Estimativas dos custos da colhedora para as 16 Capacidades Operacionais com base em 4 diferentes Eficiências de Campo.................................................................79

47. Relação entre a Capacidade Operacional e o custo por tonelada colhida.................79 


\section{LISTA DE TABELAS}

1 Valores médios encontrados no canavial, antes da colheita, para colmos, ponteiros,

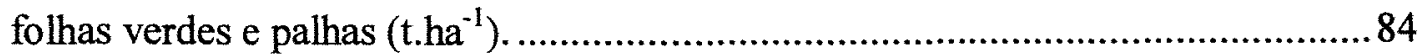

2 Quantidades médias de colmos nas 16 repetições do ensaio $\left(\right.$ t.ha $\left.{ }^{-1}\right)$.........................84

3 Resumo da análise da variância, para a variável peso da matéria-prima colhida nas

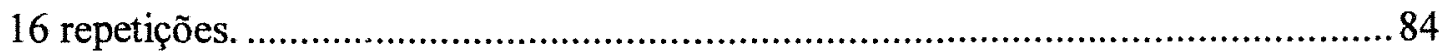

4 Resultados das determinações do porte do canavial, nas 12 repetições. ....................84

5 Comprimento médio dos colmos, média de 13 repetições...........................................84

6 Resumo da análise da variância para a variável velocidade média.............................85

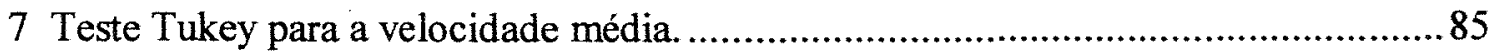

8 Resumo da análise da variância para Capacidade Efetiva Bruta.................................85

9 Teste Tukey para Capacidade Efetiva Bruta. .............................................................85

10 Resumo da análise da variância para a variável Eficácia de Manipulação...............86

11 Resumo da análise da variância para Capacidade Efetiva Líquida. .........................8 86

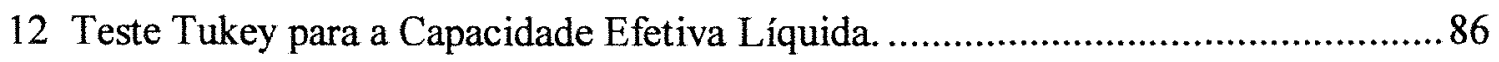

13 Resumo da análise da variância da interação entre a velocidade e o consumo de

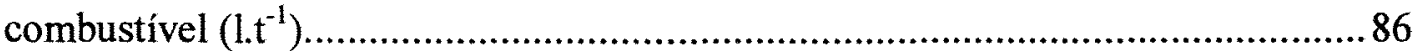

14 Resumo da análise da variância da interação entre a velocidade e o consumo de combustivel $\left(1 . h^{-1}\right)$.

15 Teste Tukey, para a interação entre a velocidade e o consumo de combustível $\left(1 . t^{-1}\right)$.

16 Teste Tukey, para a interação entre a velocidade e o consumo de combustível $\left(1 . h^{-1}\right)$

17 Resumo dos resultados análise de desempenho da colhedora.

18 Resumo da análise da variância para perda de colmos e frações de colmos.

19 Resumo da análise da variância para as perdas na forma de rebolos. 
20 Teste Tukey, para as perdas na forma de rebolos................................................8

21 Resumo da análise da variância para as perdas na forma de frações de rebolos...... 88

22 Resumo da análise da variância para as perdas na forma de frações de colmos na

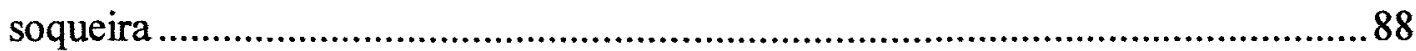

23 Teste Tukey para as perdas na forma de frações de colmos na soqueira..................89

24 Resumo da análise da variância para a variável raízes arrancadas pela máquina. ...89

25 Teste Tukey para a variável raízes arrancadas pela máquina...................................89

26 Resumo da análise da variância para a variável perdas totais de matéria-prima.......89

27 Resumo das análises das perdas de matéria-prima no campo da colhedora e total de

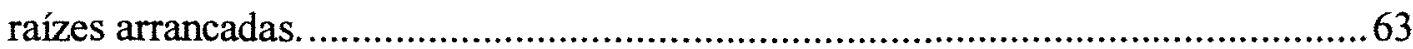

28 Resumo da análise da variância para a variável Índice de Ponteiros........................90

29 Resumo da análise da variância para a variável Índice de Folhas............................90

30 Teste Tukey para a variável Índice de Folhas. .....................................................90

31 Resumo da análise da variância para a variável Índice de Palhas. ............................90

32 Resumo da análise da variância para a variável Índice de Raízes............................90

33 Teste Tukey para a variável Índice de raízes.........................................................91

34 Resumo da análise da variância para a variável Índice de Matéria Estranha

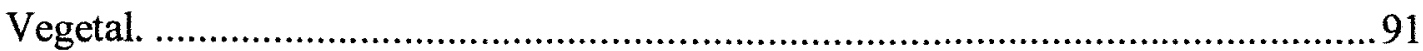

35 Resumo da análise da variância para a variável, Índice de Matéria Estranha Mineral.

36 Teste Tukey para a variável Índice de Matéria Estranha Mineral..........................91

37 Resumo da análise da variância para a variável Índice de Matéria Estranha Total..92

38 Resumo dos resultados da matéria estranha contida na matéria-prima. ……….......70

39 Resumo da análise da variância para as variáveis da qualidade tecnológica da matéria-prima.

40 a 55 Fluxos de caixa da colhedora nas velocidade e Eficiências de Campo estimada, constituindo-se nas Capacidades Operacionais expressas em $\left(\mathrm{t} . \mathrm{h}^{-1}\right)$.

56 Parte final do fluxo de caixa, com o resumo dos resultados para as 16 capacidades operacionais estimadas, considerando-se 18.000 horas de vida útil, com seus com seus respectivos custos. 


\section{LISTA DE SÍMBOLOS E ABREVIATURAS}

US\$. $\mathrm{h}^{-1}=$ Dolar por hora

US $\$ . t^{-1}=$ Dolar por tonelada

$\mathrm{CEb}=$ Capacidade Efetiva Bruta

$\mathrm{COp}=$ Capacidade Operacional

$\mathrm{EM}=$ Eficácia de Manipulação

$\mathrm{Ef}=$ Eficiência de Campo

$\mathrm{CEl}=$ Capacidade Efetiva Líquida

Veloc. $=$ Velocidade

IP = Índice de Ponteiros

IF = Índice de Folhas

IP = Índice de Palhas

$\mathrm{IR}=$ Índice de Raízes

IV = Índice de Matéria Estranha Vegetal

$\mathrm{IM}=$ Índice de Matéria Estranha Mineral

IT = Índice de Metéria Estranha Total 


\title{
DESEMPENHOS OPERACIONAL E ECONÔMICO DE UMA COLHEDORA EM CANA CRUA
}

\author{
Autor: MOIZÉIS SILVA NERY
}

Orientador: Prof. Dr. TOMAZ CAETANO CANNAVAM RIPOLI

\section{RESUMO}

Os resultados de avaliação dos desempenhos operacional e econômico de colhedora operando em cana crua oferecem subsídios que auxiliam a tomada de decisão na implantação de sistemas de colheita. O objetivo deste trabalho foi o de avaliar os aspectos operacionais e econômicos de uma colhedora sob condições de cana crua. Os ensaios foram realizados na Usina da Barra, município de Barra Bonita, Estado de São Paulo, no período de 07 a 17 de Julho de 1998. A colhedora utilizada foi de origem nacional, ano de fabricação 1997, com motor de 325 hp e rodados de esteiras. A variedade utilizada foi a RB 83-5089, em terceiro corte, com espaçamento entre fileiras de $1,40 \mathrm{~m}$. O solo foi classificado como Latossolo Roxo-Argiloso, com declividade de $2,0 \%$, previamente sistematizado para a colheita mecânica. A caracterização das condições de campo e do desempenho operacional foram realizadas pelo método proposto por Ripoli (1996). A análise econômica foi efetuada pelo método proposto por Noronha et al.(1991). A área de ensaio foi caracterizada como sendo: canavial de porte 
ereto, massa total 176,26 t.ha ${ }^{-1}$, massa de colmos 145,39 th.ha $^{-1} \mathrm{e}$ comprimento médio dos colmos $3,26 \mathrm{~m}$. A máquina foi ensaiada em quatro velocidades de deslocamento: 1,5, 3,0, 5,0 e $7,0 \mathrm{~km} \cdot \mathrm{h}^{-1}$, com quatro repetições por velocidade, totalizando 16 determinações, em delineamento estatístico inteiramente casualisado. Cada repetição correspondeu a uma distancia de $100 \mathrm{~m}$ ao longo da fileira de plantio. Foram determinados os seguintes parâmetros de desempenho: Capacidade Efetiva Bruta, Capacidade Operacional, Eficácia de Manipulação, Capacidade Efetiva Líquida, Consumo de Combustível, Perdas de Matéria-prima no campo, Raízes arrancadas pela máquina, Índice de Matéria Estranha na matéria-prima, Qualidade tecnológica da matéria-prima, Freqüência de comprimento dos rebolos, Índice de Cisalhamento dos Rebolos e o Custo Operacional da colhedora. Após as análises e discussões dos resultados obtidos chegou-se as seguintes conclusões: o aumento da velocidade de deslocamento da colhedora provocou aumento nas Capacidade Efetiva Bruta, Capacidade Operacional, Quantidade de raízes arrancadas e no Índice de Cisalhamento dos Rebolos e a diminuição dos Consumo de Combustível por tonelada colhida, Comprimento dos Rebolos e Custos de colheita. Não houve influência da velocidade de deslocamento sobre as Perdas Totais de Matéria-prima, Índice de Matéria Estranha Total e da Qualidade Tecnológica da Matéria-prima. 


\title{
OPERATIONAL AND ECONOMIC PERFORMANCE OF A SUGAR CANE HARVESTER IN GREEN CANE
}

\author{
Author: MOIZÉIS SILVA NERY \\ Adviser: Prof. Dr. TOMAZ CAETANO CANNAVAM RIPOLI
}

\section{SUMMARY}

The results of the evaluation of the operational and economical performances of a harvester operating in green cane offer subsidies, that can help the decision about in machinery to be choosed. The goal of this work was to evaluate the operational and economic aspects of one harvester working in green cane. The field test were conducted on Usina da Barra, located in Barra Bonita district, in the São Paulo State, in the season between 07 and 17 of July of 1998. The harvester utilized for this test was Brazilian home made, model 1997 with an engine of $320 \mathrm{hp}$, with wheel tracks. The variety studied in this work was the RB 83-5089, in third cut, with space between rows of $1,40 \mathrm{~m}$. The soil was classified as a loamy latossolo, with $2 \%$ declivity, previously systematized for mechanical harvest. The characterization of field conditions and operational performance were realized with Ripoli (1996) method. The economical analysis was effected with the Noronha et al. (1991) methodology. The area in this test was characterized as a straight sugar cane condition, with a total mass of $176,26 \mathrm{t}^{-\mathrm{ha}^{-1}}$, 
cane stalk mass of $145,39 \mathrm{t}^{-\mathrm{ha}^{-1}}$ and a cane mean size of $3,26 \mathrm{~m}$. The machine was tested in four speeds: $1,5,3,0,5,0$ and $7,0 \mathrm{~km}^{-1}$, with four repetitions each in a distance of $100 \mathrm{~m}$ inside of the area, giving a total of 16 determinations in an total randomized statistical delineation. The variables considered were: Effective Gross Capacity, Operational Capacity, Manipulation Efficiency, Effective Net Capacity, Total Losses of sugar cane prime matter on the field, Fuel Consumption, Industrial cane quality, Operational Costs of the harvester, Length Frequency of Billets and Shearing Billet Index. After all the analyses and discussions the obtained results pointed to following conclusions: The increase of the harvest speed increased all the Effective Gross and Operational Capacities, it increases too the Quantity of Roots pulled out from the field by the machine and finally it increases the Shearing Billet Index. By the other hand the harvest speed decreases the Fuel Consumption for every harvested ton of cane, the Length of Billets and the Harvest Costs. There were no influences of harvest speed on the Total Cane Prime Matter Losses, Total Strange Matter Index and Industrial Cane Quality. 


\section{INTRODUÇÃO}

A cultura da cana-de-açúcar (Saccharum spp) ocupa no Brasil uma área de $4,97.10^{6}$ hectares, com uma produção de 338 milhões de toneladas.ano ${ }^{-1}$ (IBGE, 1998), que fornece ao país uma economia de aproximadamente 5,3 bilhões de dólares anuais, constituindo-se em uma das culturas de maior expressão econômica.

O Estado de São Paulo é o maior produtor brasileiro de cana-de-açúcar, sendo sua produção destinada à fabricação de açúcar e de álcool, revelando-se na maior agroindústria do Estado. A cana-de-açúcar se destaca pela sua importância econômica e social, uma vez que é responsável pelo maior volume das exportações e do consumo interno do produto, bem como pela mão-de-obra absorvida e pela oferta de empregos.

Porém, a produção de cana-de-açúcar vem sofrendo ajustes no que se refere ao sistema de colheita, onde a queima como prática de pré-colheita gerou uma série de controvérsias nos aspectos energéticos, ambientais e sociais, fazendo com que o governo estadual elaborasse decreto restringindo essa queima como prática auxiliar na operação de colheita.

Outro aspecto a considerar diz respeito à quantidade de energia da biomassa que se deixa de aproveitar com a queima da cana no processo de colheita. Para Ripoli (1990), a palhada remanescente da colheita sem queima prévia representa a mesma quantidade de energia que se pode obter com a produção de álcool em cada hectare colhido. Uma vez que a disponibilidade dos recursos energéticos, como petróleo e hidrelétricas, continuam sendo questionáveis, pode-se utilizar a palha da cana como fonte de energia. 
O sistema de colheita mecanizada em canaviais sem queima prévia surge como uma alternativa no ponto de vista ambiental e energético, porém nos aspectos técnicos, econômicos e sociais o mesmo continua sendo discutível, visto que este sistema ainda depende de um processo de avaliação sob condições brasileiras para a caracterização de sua viabilidade técnica e econômica.

A avaliação dos desempenhos operacional e econômico de colhedora, em cana crua, se justifica por oferecer subsídios que podem auxiliar os técnicos e empresários envolvidos no setor canavieiro no momento da tomada de decisão, para o processo de implantação do sistema de colheita mecânica sob essa condição de canavial.

Como hipótese, o presente estudo tenta desenvolver o conceito de que as maiores velocidades de deslocamento da colhedora aumentam significativamente os desempenhos operacional e econômico da colheita, mesmo quando se trata de operação em cana crua.

Assim, este trabalho teve como objetivo analisar aspectos operacionais e econômicos da colheita mecanizada da cana-de-açúcar, sob condições de cana crua. 


\section{REVISÃO BIBLIOGRÁFICA}

\subsection{A cultura da cana-de-açúcar no Brasil}

A cana-de-açúcar sempre originou um dos principais produtos de consumo e exportação do Brasil. Seu início foi nos séculos XVI e XVII, na preponderância do açúcar na economia colonial, onde a produção para exportação, aliada às condições favoráveis de solo e clima para o desenvolvimento da cultura, constituiu-se na principal causa da ocupação territorial brasileira, (Arruda, 1979).

Carvalho (1993) cita que a produção de cana-de-açúcar passou por períodos variados, porém, sempre apresentando crescimento tanto na área cultivada quanto na quantidade colhida. De 1901 a 1950, a produção aumentou em cinco vezes; já, de 1950 a 1970, quadruplicou. No ano de 1975, com a implantação do Proálcool, a produção de cana-de-açúcar passou de 68 milhões de toneladas para 223 milhões no ano de 1991.

Em termos econômicos, o setor sucroalcooleiro representa 1,7\% do produto interno bruto (PIB) do Brasil e 17\% do PIB agrícola do Estado de São Paulo (ÚNICA, 1996) $)^{1}$.

O Estado de São Paulo é o maior produtor nacional, com uma produção de $200.10^{6}$ toneladas e uma área cultivada de $2,5.10^{6}$ hectares (IBGE, 1997), sendo sua produção destinada à fabricação de açúcar e de álcool, alcançando posição de destaque na agroindústria deste Estado.

\footnotetext{
${ }^{1}$ ÚNICA: União da Agroindústria Sucroalcooleira do Estado de São Paulo. 1996.
} 


\subsection{Colheita da cana-de-açúcar}

Segundo Pinto (1976), a colheita da cana-de-açúcar, em todo o sistema açucareiro internacional antes da II Guerra Mundial, era efetuada à mão, e sem queima prévia por cortadores que utilizavam facões de diferentes tipos. Os mesmos faziam feixes, que eram transportados e colocados nos veículos de transportes por outros operários. Dessa forma, a matéria-prima chegava às usinas em condições ideais, perfeitamente limpa e preservada. Com a falta de mão-de-obra durante a Segunda Guerra Mundial, o Havaí, e em menor escala a Austrália, fizeram a queima da cana antes da colheita, pois naquele momento não havia interferência na qualidade da matériaprima, onde as folhas eram destruídas, facilitando o corte e elevando ao dobro o desempenho dos operários. Logo após o aparecimento da queima dos canaviais, surgiram as primeiras carregadoras mecânicas. Mesmo assim, não houve a solução do problema no Havaí, quando se fez necessário adaptar bordas cortantes de lâminas de terraplanagem montadas em tratores de esteiras, que arrebentavam a cana ao nível do solo, e em seguida empurravam a cana até a estrada. As grandes garras mecânicas adaptadas em escavadoras automotrizes, carregavam os montes de cana de 2 a 4 toneladas nos veículos de transportes com capacidade de 20 a 40 toneladas. A Thompson, nos EUA, na década de 50, lançou máquinas que também cortavam, porém, elevavam e carregavam simultaneamente no veículo de transporte a cana inteira. No final da década de 50, surge na Austrália, um novo conceito, que viria a solucionar a mecanização da colheita da cana-de-açúcar, ou seja, a máquina que corta, pica, limpa e carrega a cana-de-açúcar. Estas máquinas começaram a substituir o sistema de corte mecânico de cana inteira em 1960. Em 1970 o sistema de colhedora combinada detinha 95\% da mecanização da colheita na Austrália, e se expandiu para outros países.

Nos anos 60, a Massey Ferguson introduziu no país a primeira colhedora tipo corta-pica-carrega, importada da Austrália, mas sem sucesso. $\mathrm{Na}$ década de 70 , foram produzidas 80 colhedoras de cana-de-açúcar, com formato de cesto (Santal Modelo CTD) e de esteira (Santal Modelo CTE). Em 1973, a Santal fabrica e lança no Brasil a colhedora que corta-pica-limpa e carrega. Neste período, o mercado expande 
definitivamente para este modelo de máquina, sendo feitas importações da Austrália dos modelos MF 201, MF 102, Toft Robot 300, e da Alemanha a Claas modelo Libertadora, (Pinto, 1977).

\subsection{Colheita da cana-de-açúcar em cana queimada e em cana crua: implicações técnicas, ambientais e sociais.}

Com relação à queima prévia dos canaviais, devem-se considerar aspectos como: a) Agronômicos: a queima do palhiço diminui o potencial de matéria orgânica no solo, predispondo-o à ação mais agressiva das chuvas, expondo-o à ação dos raios solares que provocam o seu resecamento, favorece ao desenvolvimento de ervas daninhas. Como vantagens agronômicas, têm-se: facilidade nas práticas de cultivo das soqueiras e de adubação, aumento no teor de cinzas no solo, eliminação de brocas da cana-de-açúcar e das cigarrinhas; b) Industriais: a industrialização, após 72 horas, apresenta problema nos teores de brix, sacarose, fibra, na purificação e na conservação do caldo, aumento da acidez e da taxa de microorganismos, devido à ocorrência da exudação do caldo na superfície do colmo, predispondo-o à deterioração rápida; c) Econômicos e operacionais: há diminuição nos custos de colheita de $30 \%$ a $50 \%$, a operação é facilitada tanto para o corte manual como mecânico, há maior incidência de prejuízos em caso de chuvas após a queima, que aliadas a altas temperaturas provocam deterioração mais rápida, maior consumo de água na lavagem das canas, em virtude da matéria estranha estar aderida às suas ceras solubilizadas dos exudados das células; d) Energético: o processo da queima da cana-de-açúcar perde $30 \%$ da matéria bruta e 15\% de matéria seca, que poderiam ser transformadas em energia elétrica ou em biogás (Delgado, 1985).

A queima prévia constitui em uma eficiente operação de limpeza dos canaviais, influenciando positivamente o desempenho operacional do corte manual, minimizando, assim, o esforço físico dos operadores (Ripoli \& Mialhe, 1987).

A queima prévia dos canaviais se expandiu devido aos reflexos econômicos imediatos, gerando diversos inconvenientes como: incêndios em outras áreas agricolas 
ou matas, danos às redes de energia elétrica, impedimento da implantação do controle biológico de pragas, perda de sacarose por exudação dos colmos e diminuição em média de 10 t.ha $^{-1}$ de massa vegetal que poderia ser incorporada ao solo, melhorando as propriedades físicas e químicas, ou ainda ser utilizada como fonte de energia (Ripoli, 1988).

Bassinello et al. ( $\mathrm{s} / \mathrm{d}$ ) mostram aspectos positivos e negativos da colheita da cana crua, com a permanência dos restos da cultura no campo. As vantagens são: conservação da umidade do solo, diminuição da quantidade de herbicidas para controlar as ervas daninhas, melhor controle da erosão, aumento da matéria orgânica disponível no solo, redução da população de nematóides, aproveitamento da palha na indústria como fonte de energia, melhor qualidade da matéria-prima oferecida à indústria, para pequenos produtores a possibilidade da colheita parcial do talhão para aproveitamento dos ponteiros na alimentação animal e redução da poluição atmosférica. As principais desvantagens apresentadas foram: baixo desempenho no corte tanto manual quanto mecânico, aumento na matéria estranha vegetal e mineral na matéria-prima, aumento das perdas no campo e menor brotação da soqueira em virtude do sombreamento, dificuldade de operação com os implementos para tratos culturais da lavoura, maior uso de nitrogênio em função da imobilização deste elemento na decomposição da palha, maiores riscos de incêndio tanto na colheita quanto na entressafra, aumento no teor de fibra, o que diminui a eficiência das moendas, redução no desempenho operacional das colhedoras, elevando os custos operacionais, aumento na incidência de broca e de cigarrinha da raiz.

Ripoli et al. (1990) comentam que o processo de colheita com queima prévia deverá ser substituído pelo sistema de colheita de cana crua, por benefícios de ordem técnica, econômica, ambiental e agronômica. $\mathrm{O}$ palhiço remanescente da colheita de cana crua representa praticamente a mesma quantidade de energia que pode se obter com a produção de álcool em um hectare. As queimadas representam um desperdício de energia, e a colheita de cana sem queima prévia merece uma nova atenção por parte dos pesquisadores, empresas sucroalcooleiras e do governo, uma vez que sua adoção deverá 
beneficiá-los, além de diminuir os impactos ambientais e oferecer ao país uma nova matriz energética que pode contribuir para minimização da crise de energia.

A expansão dos canaviais no Brasil para suprimento da demanda de álcool tem provocado muitas discussões diante da queima como prática de colheita. Os problemas são de ordem ambiental, sendo a queima acusada de provocar poluição atmosférica, destruição da fauna e da flora, entre outros. A colheita sem queima prévia é uma prática agrícola recente, e as máquinas apropriadas ainda apresentam alguns problemas de operação (Molina Jr. et al. 1995).

Segundo Andrade Silva (1997), a eliminação da queima da cana-de-açúcar a curto prazo pode gerar alguns impactos de ordem socioeconômica, além de restrições técnicas e operacionais. Entre eles se destacam: somente $60 \%$ da área do Estado de São Paulo é considerada mecanizável; com a suspensão de $54 \%$ da mão-de-obra tem-se uma perda de aproximadamente 90.000 postos de trabalho. As áreas não são totalmente sistematizadas para que as máquinas efetuem a colheita da cana crua. Existem limitações das máquinas no que se refere à declividade superior a $12 \%$, havendo necessidade de 1.700 colhedoras, cuja disponibilidade no mercado e recursos econômicos necessários a sua aquisição são inexistentes. Portanto, a colheita da cana sem queima prévia deve ser implantada a médio prazo, e de forma gradativa.

O Decreto $n^{\circ} 42.056 / 97$ revoga os Decretos $n^{\circ} 28.895 / 88$ e 28.818/88, e altera o artigo $5^{\circ}$ do Decreto $n^{0} 41.719 / 97$, que dispõe sobre uso, conservação e preservação do solo agrícola, ficando a prática da queima como método auxiliar na colheita no Estado de São Paulo proibida, admitida apenas excepcionalmente e em caráter transitório, na seguinte conformidade: a) em áreas onde a colheita é mecanizável, a redução da queima será efetuada em $25 \%$ a cada dois anos, sendo que em oito anos a queima será totalmente eliminada; b) nas áreas em que a colheita não é mecanizável (declividade maior que $12 \%$ ), a redução da queima será efetuada ao ritmo de $13,35 \%$ a cada dois anos, sendo que, em quinze anos, a mesma será totalmente eliminada. A queima está proibida nos seguintes locais e situações: 1) no raio de $1 \mathrm{~km}$ dos núcleos urbanos; 2) em áreas contidas por faixa, em metros de cada lado sobre as linhas de transmissão de energia elétrica, de acordo com quantidade de kw expressa no Decreto; 3 ) é exigida uma 
distância de cinqüenta metros das ferrovias e rodovias estaduais e federais; 4) há o limite de distância de 30 metros dos canaviais para as áreas de preservação permanente, reservas florestais, matas ciliares dos rios, lagos e nascentes.

Goulart (1997) apresentou estudos sobre causas de internações em 54 hospitais nas 21 cidades da região canavieira de Ribeirão Preto, no período de 1988 a 1990. Constatou que a principal causa das internações foram doenças no aparelho respiratório. Ocorreram 60.000 casos de internações provocadas por estas doenças e 2:739 óbitos. A poluição atmosférica resultante da queima de canaviais no momento da colheita põe em risco a saúde, o bem-estar e a qualidade de vida das pessoas.

A prática da queima dos canaviais pode causar doenças á população, sendo as mais graves relacionadas a queimaduras e asfixias, e, as mais leves, são as irritações nervosas provocadas pelos gases da queima. O monóxido de carbono $(\mathrm{CO})$ provoca asfixia celular sistêmica, que impede as trocas de oxigênio pelas células, podendo causar intoxicações graves, além de ser cumulativa no organismo. Estes gases provocam lesões no sistema respiratório, onde caso o poluente seja carcinogênico, o risco de provocar câncer aumenta exponencialmente (Bohm, 1998).

Silva \& Frois (1998) citaram que a combustão completa da palha da cana tem causado grande impacto ambiental na emissão de gases e partículas, como também na formação de compostos orgânicos. No Brasil foram realizados trabalhos de coleta de material após a queima dos canaviais, sendo identificados 40 hidrocarbonetos policíclicos aromáticos (HPAs), compostos estes que possuem propriedades cancerígenas quando absorvidos pela população.

Veiga Filho et al. (1995), estudando os impactos no emprego em decorrência da substituição da mão-de-obra pela máquina na colheita da cana-de-açúcar, fizeram uma projeção para o período de 1994 a 2000, onde afirmam que haveria uma perda de 38.166 postos de trabalho na colheita da cana. Na região de Piracicaba, a taxa de desemprego inicial seria de $7,5 \%$, e no ano 2000 poderia chegar a $22,9 \%$ para uma área mecanizada de $46 \%$. Na região de Ribeirão Preto, onde a taxa de mecanização é de $50 \%$, e a área mecanizável de $60 \%$, a taxa de desemprego poderia variar de 18\% em 1994 para 51\% em 2000, com uma perda acumulada de 28.197 postos de trabalho. 
Romanach \& Caron (1999), fizeram estudo de caso sobre impactos no emprego, e os custos da colheita manual e mecanizada. O custo da colheita mecanizada foi $55,44 \%$ menor que o custo da colheita manual. A adoção da colheita mecanizada proporcionará uma dispensa de $18,27 \%$ de pessoal na época da safra. A colheita deixa de ser a maior empregadora de mão-de-obra na cultura da cana-de-açúcar. Os autores citam que novas alternativas de geração de empregos deverão ser criadas, bem como a préqualificação dos trabalhadores atuais, sendo necessário também o estabelecimento de políticas para os pequenos fornecedores, que não possuem condições favoráveis á mecanização da colheita.

\subsection{Colheita da cana-de-açúcar em cana crua: questões operacionais e econômicas.}

Fernandes \& Oliveira (1977) apresentaram valores para o percentual de matéria estranha encontrado na matéria-prima, por diversos autores e em diferentes países para a colheita mecânica por colhedora combinada:

\begin{tabular}{llc}
\hline \multicolumn{1}{c}{ Autores } & \multicolumn{1}{c}{ Países } & Índices (\%) \\
\hline Bittenccurt & Cuba & 4,19 \\
Le Blank & Lousiana (EUA) & 5,19 a 7,37 \\
Lopes Hernandes & Tucman (Argentina) & 10,0 \\
Castro \& Balceri & Porto Rico (EUA) & 10,90 \\
Hunbert & México & 9,0 a 12,0 \\
Clayton \& Wittemore & Flórida (EUA) & 13,0 \\
Smith & Jamaica & 6,0 a 19,0 \\
Niestrath & Lousiana (EUA) & 20,0 \\
\hline
\end{tabular}

Tambosco et al. (1977), estudaram colheita mecânica de cana-de-açúcar em canaviais queimados no Estado de São Paulo. As colhedoras analisadas foram: Toft Robot 300, Santal 115, Massey Ferguson 201 e Class libertadora 1400. As perdas de matéria-prima encontradas no campo foram de 10,7 t.ha ${ }^{-1}, 16,81$ t.ha ${ }^{-1}, 17,13$ t.ha ${ }^{-1} \mathrm{e}$ 15,60 t. ha ${ }^{-1}$, respectivamente. 
Fors \& Arias (1977), avaliando os efeitos da qualidade da matéria-prima no desempenho de fábrica em El Salvador, verificaram que o aumento de $1 \%$ de terra e folhas acrescentou $0,30 \%$ e $0,36 \%$ no teor de fibra, e o aumento de $1 \%$ de ponteiros e raízes provocou decréscimos de $0,15 \%$ e $0,39 \%$ na pureza do caldo.

Ripoli (1977), avaliou parâmetros de desempenho de três colhedoras de cana-deaçúcar: Santal 115, Toft-Rabot 300 e Massey Ferguson 201, nas condições do Estado de Alagoas em canaviais previamente queimados, encontrando os seguintes resultados.

\begin{tabular}{lc}
\hline \multicolumn{1}{c}{ Parâmetros } & Faixa de valores(\%) \\
\hline Eficácia de manipulação & $71,97-94,55$ \\
Matéria estranha total & $3,78-15,72$ \\
Ponteiros & $1,99-11,25$ \\
Folhas e palhas & $0,13-3,74$ \\
Raizes & $0,00-1,25$ \\
Matéria estranha mineral & $0,08-3,85$ \\
Material não selecionado & $0,09-2,31$ \\
\hline Tamanho dos rebolos & $0,20-0,30(\mathrm{~m})$ \\
Capacidade efetiva & $37,8-49,5\left(\mathrm{t} \cdot \mathrm{h}^{-1}\right)$ \\
\hline
\end{tabular}

Furlani Neto et al. (1980), analisaram cargas de cana-de-açúcar em canaviais previamente queimados, colhidos mecanicamente pela colhedora Massey Ferguson 201, Santal $115 T$ e Toft-Robot 300 na Usina da Barra Estado de São Paulo. Os índices de matéria estranha obtidos variaram em torno de $3,32 \%$ a $6,79 \%$.

De Beer (1980) avaliou colheita mecânica de cana-de-açúcar na África do Sul, verificando que a cana sem matéria estranha que continha $13 \%$ de sacarose, quando apresentou índices de matéria estranha de $5,10 \%$ e $20 \%$ reduziram o percentual de sacarose para $12,4,11,7 \%$ e $10,4 \%$ respectivamente. Com relação as perdas no campo, foram encontrados valores variando de $2,0 \%$ a $10,0 \%$. As perdas invisíveis encontradas variaram em torno de $3,0 \%$ a $6,0 \%$.

Ripoli \& Alves Berto (1981), analisaram colhedora de cana-de-açúcar na Usina Santa Cruz na região de Campos, Estado do Rio de Janeiro, em canaviais sem queima 
prévia, utilizando a colhedora Santal 115 na colheita da variedade $C B$ 45-3, no seu terceiro corte. Os valores determinados para as perdas foram de $6,5 \%$.

Izumi \& Ueno (1983), fizeram trinta ensaios no Japão para verificar perdas de matéria-prima no campo provocadas pela colhedora de cana Austoft 7000 em canaviais sem queima prévia. As perdas de matéria-prima variaram em torno de $10 \%$ a $15 \%$.

Ripoli \& Mialhe (1983), estudando custos de colheita da cana-de-açúcar no Estado de São Paulo na safra de 81/82, encontraram valores para dois sistemas de colheita: a) o manual, com carregamento mecânico e b) mecanizado por colhedora combinada, em função de três níveis de vida útil. No primeiro nível, com $100 \mathrm{mil}$ toneladas de vida útil, o corte manual com carregamento mecânico apresentou um custo de US $\$ . t^{-1} 3,02$, sendo este o menor custo de colheita. No segundo e terceiro niveis de vida útil, 200.000 e 300.000 toneladas, o subsistema mecanizado por colhedora combinada obteve os menores custos, ou sejam US $\$ . t^{-1} 2,20$ e 1,88 , respectivamente. O subsistema de colheita mecânica por colhedora combinadas constitui uma opção técnica economicamente viável para os canaviais brasileiros.

Smith et al. (1985) estudaram a colheita da cana-de-açúcar em canaviais sem queima prévia na Austrália, nas safras 79 a 83, e determinaram índice de matéria estranha variando de $7,41 \%$ a $8,24 \%$.

Fernandes \& Irvine (1986) citaram trabalhos sobre colheita mecânica de canade-açúcar na África do Sul, onde determinaram índice de matéria estranha na carga folhas e pontas de $6,0 \%$ a $17,0 \%$, respectivamente. A quantidade de matéria estranha mineral na matéria-prima ficou em torno de $0,3 \%$. As perdas em campo variaram na faixa de $2,0 \%$ a $10,0 \%$.

Herrera \& Linares (1986) fizeram estudos para verificar a eficiência de limpeza e as perdas provocadas pela colhedora KTP-1 em canaviais sem queima prévia, na província de Cienfuegos, em Cuba. Os valores encontrados para índice de matéria estranha, índice de ponteiros e índice de palha foram 10,0; 7,9 e 2,0\%, respectivamente.

Ridge \& Dick (1987) estudaram novos métodos para avaliação de desempenho de colhedora de cana na Austrália. Os valores encontrados para índice de matéria 
estranha e perdas de matéria-prima para duas colhedoras em canaviais sem queima prévia, são apresentados a seguir:

\begin{tabular}{ccccccc}
\hline \multicolumn{2}{c}{ VT 7000 } & & \multicolumn{3}{c}{ VT 6000 } \\
\hline & $\begin{array}{c}\text { Perdas } \\
(\%)\end{array}$ & Matéria & Matéria & Perdas & Matéria & Matéria \\
& & inicial (\%) & final (\%) & & inicial (\%) & final (\%) \\
\hline C/despontador & 14,9 & 17,0 & 5,8 & - & - & - \\
S/despontador & 15.6 & 25,8 & 9,3 & 16,4 & 29,5 & 9,7 \\
\hline
\end{tabular}

Broussard (1987), estudando critérios para a seleção de máquinas colhedoras de cana-de-açúcar, na Lousiana (EUA), fez avaliação dos custos de três modelos de colhedoras existentes no mercado. Os custos de colheita foram calculados pela relação entre a capacidade operacional e o custo-hora da colhedora. Os valores dos custos de colheita encontrados para os três modelos variaram de US $\$ . t^{-1} 1,0,2,0,3,0,4,0$ a 10,5 , para as capacidades operacionais de $80,0,40,0,20,0,15,0$ e 5,0 t.h $\mathrm{h}^{-1}$, respectivamente.

Furlani Neto et al. (1989), avaliaram a influência do dessecante na colheita mecânica da cana-de-açúcar em São Paulo, verificaram que a capacidade efetiva da colhedora em canavial sem queima prévia com dessecante foi de $57,16 \mathrm{t} . \mathrm{h}^{-1}$, cerca de $95,6 \%$ da capacidade efetiva em cana previamente queimada. Sem o dessecante a capacidade efetiva foi de $59,82 \mathrm{t}^{-\mathrm{h}^{-1}}$. Não houve influência da queima e do dessecante sobre a qualidade e as perdas da matéria-prima. 
Rozeff (1989) realizou ensaios para verificar os efeitos da velocidade de operação de colheita sobre o desempenho da colhedora, em canaviais com e sem queima prévia no Estado do Texas (USA). A máquina estudada foi a Claas 1400, em quatro diferentes velocidades de deslocamento, na variedade $C P$ 70-321. Os resultados de desempenho, cisalhamento e comprimento dos rebolos obtidos em canaviais sem queima prévia, são apresentados a seguir:

\begin{tabular}{lcccc}
\hline \multicolumn{1}{c}{ Parâmetros } & \multicolumn{5}{c}{ Valores } \\
\hline Velocidades $\left(\mathrm{km} \cdot \mathrm{h}^{-1}\right.$ ) & 1,42 & 2,46 & 4,18 & 5,63 \\
Capacidade efetiva bruta $\left(\mathrm{t} . \mathrm{h}^{-1}\right)$ & 17,4 & 29,5 & 54,2 & 91,6 \\
Índice de matéria estranha (\%) & 5,5 & 6,8 & 13,7 & 21,6 \\
Colmos perfeitos (\%) & 51,5 & 63,6 & 55,6 & 46,6 \\
Macerado de um lado (\%) & 21,6 & 16,0 & 15,7 & 22,7 \\
Macerado dos dois lados (\%) & 20,1 & 18,5 & 17,8 & 18,9 \\
Dilacerados (\%) & 6,8 & 1,9 & 10,9 & 11,7 \\
Comprimento dos colmos $<15 \mathrm{~cm}$ & 19,3 & 17,1 & 10,9 & 6,1 \\
Comprimento dos colmos $15-25 \mathrm{~cm}$ & 40,7 & 36,7 & 37,2 & 40,8 \\
Comprimento dos colmos $26-38 \mathrm{~cm}$ & 36,2 & 39,8 & 46,8 & 49,1 \\
Comprimento dos colmos 39-51 cm & 3,6 & 6,1 & 4,3 & 2,7 \\
Comprimento dos colmos 52-64cm & 0,2 & 0,3 & 0,8 & 1,3 \\
\hline
\end{tabular}

Cerqueira Luz \& Aloisi (1991) analisaram a influências das colheitas manual e mecânica sobre o rendimento industrial da cana-de-açúcar em Ribeirão Preto, no Estado de São Paulo. A colheita mecânica provocou redução na pureza do caldo, independentemente do estado de corte da cana-de-açúcar. Em safras consecutivas, promoveu decréscimos nos valores de Brix $\%$ do caldo, Pol \% do caldo, acréscimo na fibra \% da cana quando comparados aos valores obtidos pelo corte manual.

Shaw \& Brotherton (1992) avaliaram na Austrália a colheita mecanizada de cana-de-açúcar sem queima prévia. As perdas de matéria-prima e os índices de matéria estranha encontrados foram de $9,0 \%$ a $12,0 \%$, respectivamente. A colheita de cana crua 
influenciou positivamente a qualidade do açúcar, mesmo quando reduzidas as vantagens financeiras em comparação com a colheita em canaviais previamente queimados.

Moraes (1992), avaliou perdas invisíveis na colheita mecânica de cana-deaçúcar em condições de laboratório com a colhedora DM 6000, utilizando cana crua e queimada, operando com os extratores em condições normais de trabalho. Os resultados obtidos em cana crua nas variedades NA 56-79 e SP 71-6163 foram 4,47\% e 3,54\%, respectivamente.

Para Ripoli \& Villa Nova (1992), com o desenvolvimento tecnológico e a sistematização dos talhões, as colhedoras de cana-de-açúcar em canaviais com queima prévia apresentam capacidade efetiva em torno de $60 \mathrm{t} . \mathrm{h}^{-1}$; as perdas no campo variam na faixa de 3 a $6 \mathrm{t}^{\text {h }} \mathrm{ha}^{-1}$ e o índice de matéria estranha de $3 \%$ a $8 \%$. Porém, surge uma nova realidade: a colheita de cana crua, onde sob estas condições, tudo estaria por fazer.

Dick \& Greves-James (1992), realizaram testes com um medidor eletrônico de perda de cana em duas colhedoras da marca Austoft na Austrália, que foram testadas em velocidades diferentes, sendo que os resultados obtidos foram:

\begin{tabular}{ccc}
\hline Velocidade $\left(\mathrm{km} \cdot \mathrm{h}^{-1}\right)$ & Indice matéria estranha (\%) & Perdas totais $(\%)$ \\
\hline 5,5 & $9,9-16,1$ & $5,6-19,9$ \\
6,0 & $5,1-9,7$ & $5,5-14,1$ \\
7,0 & $8,4-13,4$ & $15,2-18,8$ \\
\hline
\end{tabular}

John (1992) relata que, na safra 91/92 na Usina São Francisco, foram colhidas cerca de 25.000 toneladas de cana-de-açúcar sem queima prévia pela colhedora Santal Rotor, protótipo do modelo Amazón, que apresentou índice de matéria estranha mineral de 0,3 a $2,0 \mathrm{~kg} \cdot \mathrm{t}^{-1}$ de cana, e índice de matéria estranha vegetal de 1,0 a $2,0 \%$. A cana colhida sem queima prévia chegou à indústria mais limpa, proporcionando uma economia de $25 \%$ nos custos industriais. A palhada deixada pela colhedora reduziu o desenvolvimento de ervas daninhas, gerando uma economia de herbicida na ordem de $10 \%$ em relação à cana colhida com queima prévia.

Romero et al. (1993) realizaram ensaios de desempenho operacional de colhedoras mecânicas Class Gladiador e Class 2000, em canaviais sem queima prévia, 
em Tucuman, na Argentina. As determinações foram realizadas em canaviais variando de 60 a 140 t.ha $^{-1}$. Os resultados obtidos para os modelos Class Gladiador e Class 2000 são apresentados a seguir:

\begin{tabular}{|c|c|c|c|c|c|}
\hline & & Class & Gladiador & & \\
\hline Variedade & $\begin{array}{l}\text { Velocidade } \\
\left(\mathrm{Km} \cdot \mathrm{h}^{-1}\right)\end{array}$ & $\begin{array}{c}\text { Capacidade } \\
\text { efetiva } \\
\left(\mathrm{t} \cdot \mathrm{h}^{-1}\right)\end{array}$ & $\begin{array}{l}\text { Perda de } \\
\text { matéria- } \\
\text { prima }(\%)\end{array}$ & $\begin{array}{c}\text { Matéria- } \\
\text { estranha } \\
(\%)\end{array}$ & $\begin{array}{c}\text { Eficiência de } \\
\text { limpeza } \\
(\%)\end{array}$ \\
\hline CP $65-577$ & 4,9 & 40 & 4,7 & 10 & 64 \\
\hline TUC $67-27$ & 3,6 & 40 & 2,8 & 13 & 62 \\
\hline NA $56-79$ & 5,7 & 51 & 7,0 & 10,7 & 65,5 \\
\hline \multirow{2}{*}{ CP $65-357$} & 5,6 & 56 & 5,7 & 12 & 60 \\
\hline & & Class & 2000 & & \\
\hline Variedade & $\begin{array}{c}\text { Velocidade } \\
\text { de trabaiho } \\
\left(\mathrm{Km} \cdot \mathrm{h}^{-1}\right)\end{array}$ & $\begin{array}{c}\text { Capacidade } \\
\text { efetiva } \\
\left(\mathrm{t} . \mathrm{h}^{-1}\right)\end{array}$ & $\begin{array}{l}\text { Perda de } \\
\text { matéria- } \\
\text { prima }(\%)\end{array}$ & $\begin{array}{c}\text { Matéria- } \\
\text { estranha } \\
(\%)\end{array}$ & $\begin{array}{c}\text { Eficiência de } \\
\text { limpeza } \\
(\%)\end{array}$ \\
\hline CP $65-357$ & 5,8 & 58 & 6,6 & 7,8 & 56 \\
\hline TU $77-42$ & 3,5 & 31 & 7,2 & 5,3 & 71 \\
\hline
\end{tabular}

Soares et al. (1994) analisaram máquinas desenvolvidas especificamente para colheita em canaviais sem queima prévia em duas safras consecutivas na Usina São Francisco, Estado de São Paulo. Os resultados obtidos foram: capacidade efetiva 60,40 t. $h^{-1}$ e capacidade operacional $22,10 t . h^{-1}$, valores considerados bastante satisfatórios. 
Hurney et al. (1994) fizeram na Austrália ensaios comparativos entre duas máquinas colhedoras de cana-de-açúcar, Claas e TX 82, em canaviais com e sem queima prévia. Os valores obtidos são os seguintes:

\begin{tabular}{clcc}
\hline \multirow{2}{*}{ Máquina } & Tipo de colheita & $\begin{array}{c}\text { Índice matéria } \\
\text { estranha }(\%)\end{array}$ & $\begin{array}{c}\text { Perdas totais } \\
(\%)\end{array}$ \\
\hline \multirow{2}{*}{ Class } & Cana crua & 4,2 & 7,0 \\
& Cana queimada & 3,7 & 5,0 \\
TX 82 & Cana crua & 1,9 & 7,6 \\
& Cana queimada & 1,8 & 3,0 \\
\hline
\end{tabular}

Lima (1994) estudou colheita mecânica em canaviais com e sem queima prévia, com a colhedora Engeagro E 8000, obtendo os seguintes desempenhos para cana crua:

\begin{tabular}{lc}
\hline \multicolumn{1}{c}{ Parâmetros } & Quantidade \\
\hline Colheita / máquina /dia( $\mathrm{t}$ ) & 500 \\
Consumo de combustível $\left(1 . \mathrm{t}^{-1}\right)$ & 1,08 \\
Consumo de óleo hidráulico $\left(1 . \mathrm{t}^{-1}\right)$ & 0,0151 \\
Perdas de matéria-prima( \% ) & 4,71 \\
Rebolos na soqueira ( \% ) & 0,82 \\
Rebolos ( \% ) & 1,49 \\
Frações de colmos (\%) & 2,16 \\
Colmos inteiros ( \% ) & 0,24 \\
Matéria estranha vegetal ( \% ) & 5,5 \\
Matéria estranha mineral ( \% ) & 0,2 \\
\hline
\end{tabular}

Ridge (1994), estudando na Austrália a colhedora de cana Austoft 7000 em canaviais com e sem queima prévia, verificou que, com a adoção da colheita nestas condições, obtêm-se resultados como: redução do tempo perdido devido à umidade provocada nos períodos chuvosos, e diminuição nos custos na colheita. Os fatores desfavoráveis foram o aumento das perdas de matéria-prima no campo, o acréscimo no 
índice de matéria estranha na matéria-prima, o aumento do consumo de combustível e os custos referentes à manutenção das colhedoras.

Furlani Neto (1995) avaliou colhedora de cana-de-açúcar em canaviais com e sem queima prévia, nas variedades SP 71-1406 e SP 71-6163. Os resultados de desempenho encontrados em canaviais sem queima prévia são apresentados na forma de porcentagem a seguir:

\begin{tabular}{lcc}
\hline \multicolumn{1}{c}{ Parâmetros } & \multicolumn{2}{c}{ Variedade } \\
\cline { 2 - 3 } & SP 71-1406 & SP 71-6163 \\
\hline Capacidade efetiva (t.h $\left.{ }^{-1}\right)$ & 59,11 & 56,36 \\
Matéria estranha vegetal (\%) & 5,59 & 10,70 \\
Matéria estranha mineral (\%) & 0,46 & 0,90 \\
Matéria estranha total (\%) & 6,05 & 11,60 \\
Perdas frações de colmos (\%) & 1,11 & 0,15 \\
Perdas colmos na soqueira (\%) & 0,70 & 0,50 \\
Perdas frações rebolos (\%) & 0,35 & 0,29 \\
Perdas rebolos (\%) & 1,69 & 0,79 \\
Perdas totais (\%) & 3,85 & 1,73 \\
Brix do caldo (\%) & 21,50 & 21,96 \\
Pol do caldo (\%) & 18,56 & 20,30 \\
Pureza do caldo (\%) & 86,28 & 92,44 \\
Fibra cana (\%) & 14,83 & 18,77 \\
Pol cana corrigido (\%) & 14,54 & 15,23 \\
\hline
\end{tabular}


O Cenicaña (1995) fez um estudo da colhedora Austoft 7700 em canaviais sem queima prévia. A coleta de dados foi feita em quatro engenhos: Riopaila, Manuelita, Mayaguez e Castilla. A produtividade média dos canaviais foram de 104 t.ha $^{-1}$, variando de 86 a 116 t.ha $^{-1}$. A colhedora trabalhou 1.263 horas, com uma eficiência de 59\%. Os resultados de desempenho são apresentados a seguir:

\begin{tabular}{cccccc}
\hline \multicolumn{4}{c}{ Colhedora Austoft 7700 } \\
\hline Capacidade & Capacidade & Velocidade de & Matéria & \multicolumn{2}{c}{ Consumo de } \\
Efetiva de & Teórica de & Trabalho & estranha & \multicolumn{2}{c}{ Combustível } \\
Campo $\left(\mathrm{t} . \mathrm{h}^{-1}\right)$ & Campo $\left(\mathrm{t} . \mathrm{h}^{-1}\right)$ & $\left(\mathrm{km} \cdot \mathrm{h}^{-1}\right)$ & $(\%)$ & $1 . \mathrm{t}^{-1}$ & $1 . \mathrm{h}^{-1}$ \\
\hline 26,74 & 45,21 & 2,82 & 9,82 & 1,32 & 35,2 \\
\hline
\end{tabular}

Furlani Neto et al. (1996) fizeram avaliação do desempenho operacional de colhedoras Santal Amazón em canaviais com e sem queima prévia, na região de Ribeirão Preto, em São Paulo. O valor encontrado para capacidade efetiva em cana crua foi de 57,78 t.h ${ }^{-1}$ de cana colhida. A qualidade tecnológica como Brix do caldo, Pol do caldo e fibra da cana foram significativamente superiores para cana crua.

O Cenicaña (1996) realizou uma avaliação de desempenho na colhedora Austoft 7700 , em canaviais sem queima prévia na Colômbia. O ensaio foi feito em uma área de 0,68 ha. A máquina permaneceu no campo por 273 minutos, dos quais $57 \%$ colhendo cana, $27 \%$ em giros (manobras) esperando vagões ou para descarregar a cana, e $5 \%$ em outras atividades. A velocidade média de colheita foi de $1,82 \mathrm{~km} \cdot \mathrm{h}^{-1}$. Os resultados de desempenho obtidos foram de capacidade efetiva de campo, capacidade teórica de campo e índice de matéria estranha na ordem de 21,8 t. $\mathrm{h}^{-1}, 38 \mathrm{t} \cdot \mathrm{h}^{-1}$ e $10,3 \%$, respectivamente.

Segundo Ripoli (1996), no Brasil são utilizados três subsistemas de colheita: a) o manual, onde o corte e o carregamento são feitos por mão-de-obra braçal; b) o semimecanizado, que apresenta o corte manual e o carregamento mecânico; c) o mecanizado, onde o corte, o carregamento e o transporte são feitos por máquinas. O subsistema mecanizado pode se apresentar de duas formas: uma, que corta o produto para um posterior carregamento mecânico, e outra, que utiliza colhedoras combinadas ou 
autopropelidas que cortam, fracionam, limpam e carregam os colmos diretamente na unidade de transporte.

As modernas colhedoras da Austrália possuem capacidade efetiva de $120 \mathrm{t}^{-\mathrm{h}^{-1}}$,

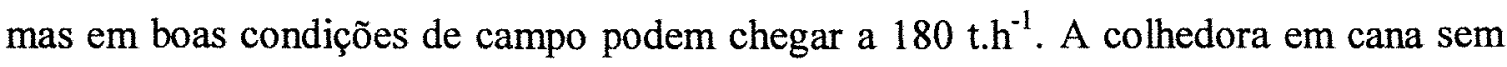
queima prévia chega a $60 \mathrm{t} \cdot \mathrm{h}^{-1}$, desempenho operacional baixo, o que pode aumentar os custos de colheita (Schembri \& Garson, 1996)

Moraes \& Neves (1997a) realizaram ensaios no Estado de São Paulo, para quantificar perdas invisíveis, na colheita de cana sem queima prévia em colhedora Austoft 7000. Os ensaios foram conduzidos sob condições controladas, o que permitiu a determinação das perdas invisíveis nas seguintes fases de processamento: corte de base, corte dos facões picadores e nos ventiladores dos extratores primário e secundário. As perdas invisíveis variaram em torno de 2,1 a $5,4 \%$. Quanto aos mecanismos, as perdas foram mais acentuadas no corte de base e nos facões picadores.

Scandaliares et al. (1997) fizeram levantamentos de 29 máquinas colhedoras de cana-de-açúcar operando em canaviais sem queima prévia, no ano de 1996, na Argentina. Os modelos das máquinas avaliadas foram os mais recentes lançados no mercado, sendo que cada uma colheu de 74.000 a 112.000 toneladas na safra em estudo. As 29 máquinas colheram de 325 a 628 toneladas por dia de safra. As perdas de tempo nas frentes de colheita foram em torno de 4,95 horas/dia, e as causas constatadas foram referentes à falta de transporte, a problemas mecânicos, à manutenção geral e a outros. $\mathrm{O}$ consumo de combustível para cada tonelada de cana colhida variou entre 0,9 a 1,6 litros. Os fatores que mais influenciaram o consumo de combustível foram o estado de umidade do canavial (épocas secas e chuvosas ao longo da colheita), a produtividade da cana $\left(\right.$ t.ha $\left.{ }^{-1}\right)$ e o comprimento dos talhões. $O$ índice de matéria estranha total variou de $5,5 \%$ a $6,5 \%$ sendo os maiores percentuais nos períodos secos, e os menores, nos chuvosos. As perdas de matéria-prima aumentaram consideravelmente quando a colheita foi efetuada durante a noite, oscilando em torno de 6,12 a $14,8 \%$. O rendimento de fábrica da matéria-prima colhida foi de $0,2 \%$ em relação à colheita semi-mecanizada.

O Cenicaña (1997a) da Colômbia fez uma avaliação em colhedoras combinadas operando em cana-de-açúcar sem queima prévia, na variedade CC 86-65 em uma área de 
4,65 ha com produtividade média de 147 t.ha ${ }^{-1}$. As colhedoras utilizadas foram: Austoft 7700 e Cameco CHT 2500. A matéria estranha colhida pelas máquinas foram de 8,3\%, perdas de matéria-prima em torno de $3,65 \%$, e eficácia de manipulação de $96,35 \%$. Os resultados de desempenho obtidos se encontram a seguir:

\begin{tabular}{lcc}
\hline \multicolumn{1}{c}{ Parâmetros } & Austoft 7700 & Cameco CHT 2500 \\
\hline Eficiência de Campo (\%) & 43 & 46 \\
Velocidade $\left(\mathrm{km} \cdot \mathrm{h}^{-1}\right)$ & 2 & 1 \\
Capacidade Efetiva de Campo $\left(\mathrm{t} . \mathrm{h}^{-1}\right)$ & 70,6 & 29,40 \\
Capacidade Teórica de Campo $\left(\mathrm{t} . \mathrm{h}^{-1}\right)$ & 47,6 & 13,40 \\
Capacidade Efetiva Líquida $\left(\mathrm{t} \cdot \mathrm{h}^{-1}\right)$ & 68,02 & 28,32 \\
\hline
\end{tabular}

Moraes \& Neves (1997b) avaliaram no Estado de São Paulo o índice de matéria estranha e as perdas de matéria-prima provocadas pela colhedora Austoft 7000, na variedade RB 72454, e encontraram os seguintes valores:

\begin{tabular}{cccc}
\hline $\begin{array}{c}\text { Rotação extrator } \\
\text { primário (rpm) }\end{array}$ & $\begin{array}{c}\text { Matéria estranha } \\
\text { vegetal (\%) }\end{array}$ & $\begin{array}{c}\text { Matéria estranha } \\
\text { mineral (\%) }\end{array}$ & $\begin{array}{c}\text { Perdas matéria-prima } \\
(\%)\end{array}$ \\
\hline 1500 & 8,5 & 0,1 & 5,6 \\
1100 & 11,2 & 0,5 & 1,4 \\
\hline
\end{tabular}

Segundo Sparovek (1997), o corte de cana-de-açúcar sem queima prévia pode acarretar vários fatores, como diminuição das emissões de $\mathrm{CO}_{2}$ e ozônio na baixa atmosfera, minimização da erosão, menor gasto de energia pelas máquinas, aumento da infiltração de água no solo, melhoria na qualidade tecnológica (diminuição da matéria estranha mineral) e maior quantidade de matéria estranha vegetal. Para a avaliação da viabilidade desta prática, é necessário o estabelecimento de critérios que orientem as decisões, e contemplem todos aspectos do trinômio: economicamente viável, socialmente justo e ambientalmente correto, ou seja o caráter interdisciplinar deve ser considerado.

Vitali \& Domanti (1997), estudaram o comprimento ótimo dos rebolos e constataram que os mesmos do tamanho de 0,20 a $0,25 \mathrm{~m}$ de comprimento obtiveram 
menores custos no transporte, menor deterioração da cana, menor índice de matéria estranha e menores perdas. Rebolos que possuem comprimento abaixo de $0,20 \mathrm{~m}$ e acima de $0,30 \mathrm{~m}$ aumentaram drasticamente os custos provocados pelo aumento de perdas, matéria estranha, deterioração e transporte da matéria-prima.

O Cenicaña (1997b) fez ensaio para avaliar a colhedora Austoft 7700 , em canaviais sem queima prévia, em uma área de 4,8 ha, com a variedade CC 85-68 de 13,4 meses de idade e produtividade média de 211 t.ha $^{-1}$. A colhedora Austoft 7700 apresentou os seguintes dados de desempenho: eficiência de campo $51 \%$, capacidade efetiva de campo 37,0 t.h ${ }^{-1}$, capacidade teórica de campo $73,0 \mathrm{t} . \mathrm{h}^{-1}$, matéria estranha em torno de $11,73 \%$.

Norris et al. (1998) estudaram alternativas apropriadas para projetos de colhedora de cana na Austrália, sendo os modelos avaliados o protótipo Massey Ferguson 405 e Austoft 7000. O tamanho dos rebolos variaram de 0,25 a $0,30 \mathrm{~m}$, não havendo diferença significativa entre as duas máquinas nas condições analisadas. Os resultados de desempenho são apresentados a seguir:

\begin{tabular}{ccccccc}
\hline Colhedora & $\begin{array}{c}\text { Velocidade } \\
\left(\mathrm{km} \cdot \mathrm{h}^{-1}\right)\end{array}$ & $\begin{array}{c}\text { Matéria } \\
\text { estranha } \\
\text { mineral(\%) }\end{array}$ & $\begin{array}{c}\text { Matéria } \\
\text { estranha } \\
\text { total (\%) }\end{array}$ & $\begin{array}{c}\text { Rebolos } \\
\text { perfeitos } \\
(\%)\end{array}$ & $\begin{array}{c}\text { Rebolos } \\
\text { danificados } \\
\text { 1-lado (\%) }\end{array}$ & $\begin{array}{c}\text { Rebolos } \\
\text { danificados }\end{array}$ \\
\hline Aust 7000 & 3 & 2,1 & 6,4 & 41,8 & 32,5 & 25,7 \\
& 5 & 2,9 & 7,1 & 36,1 & 39,0 & 24,9 \\
& 7 & 2,7 & 7,1 & 32,4 & 44,1 & 23,5 \\
M F 405 & 3 & 0.7 & 2,6 & 51,2 & 31,8 & 17,0 \\
& 5 & 2.1 & 4,6 & 45,8 & 36,1 & 18,1 \\
& 6,5 & 0,4 & 5,1 & 42,5 & 36,8 & 20,7 \\
\hline
\end{tabular}

Lima (1998) fez levantamento de dados em várias empresas das regiões produtoras de cana-de-açúcar no Nordeste, no Centro-Oeste e no Sudeste do Brasil, com o objetivo de analisar o comportamento das várias marcas de colhedoras mecânicas de 
cana-de-açúcar a saber: Amazón, Brastoft, Cameco e Class. Os resultados encontrados em $29 \%$ de cana colhida sem queima prévia são apresentados a seguir:

\begin{tabular}{|c|c|c|c|c|}
\hline Unidades & Amazón & Brastoft & Cameco & Class \\
\hline t. safra ${ }^{-1}$ & $37533-80739$ & $49035-121182$ & $91230-121268$ & $82268-95819$ \\
\hline t.dia ${ }^{-1}$ & $205-441$ & $242-645$ & $414-583$ & $388-457$ \\
\hline Comb. $\left(1 . t^{-1}\right)$ & $0,71-1,54$ & $0,81-1,56$ & $0,81-1,08$ & $0,70-1,04$ \\
\hline $\mathrm{R} \$ \mathrm{t}^{-1}$ & $1,77-3,81$ & $1,69-3,71$ & $1,64-2,32$ & $2,12-2,55$ \\
\hline$N^{0}$ dados & 10 & 15 & 5 & 3 \\
\hline
\end{tabular}

Arruda Pinto \& Nunes Jr. (1998) fizeram levantamentos sobre produtividade agrícola do setor sucroalcooleiro na safra 97 /98, nas Regiões de Centro-Sul e NordesteLeste. Classificaram as empresas por faixas, indicando a produção média por dia efetivo de safra de cada colhedora de cana picada. Os índices de matéria estranha vegetal e mineral encontrados em cana queimada previamente foram de 6,12\% e 1,07\%, respectivamente. Em canaviais sem queima prévia, os índices de matéria estranha vegetal e mineral foram de 6,60 e 1,10\%. Os autores consideraram altos os índices de matéria estranha. Os resultados da produção média por dia efetivo de safra feita com colhedora de cana crua picada são apresentados a seguir:

\begin{tabular}{ccccc}
\hline Classificação & \multicolumn{2}{c}{ Centro-Sul } & \multicolumn{2}{c}{ Nordeste-Leste } \\
\cline { 2 - 5 } Das & Faixa de & Freqüência das & Resultado & Empresas \\
Empresas & Resultados & Empresas (\%) & Médio & Pesquisadas \\
\hline Otimo & 442 a 572 & 20,00 & - & - \\
Boa & 316 a 441 & 25,00 & - & - \\
Regular & 163 a 315 & 45,00 & 260 & 2 \\
Ruim & Abaixo de 163 & 10,00 & - & - \\
\hline
\end{tabular}

Em Relatório $(1998)^{2}$ da Usina Alta Mogiana, na região de Ribeirão Preto, no Estado de São Paulo, foi fornecido um resumo contendo dados de desempenho da

\footnotetext{
${ }^{2}$ Relatório Técnico da Usina Alta Mogiana S.A. - Açúcar e Álcool. Ribeirão Preto SP. Out./ 1998.
} 
colheita mecanizada na safra 95/96/97 e 98 . Os resultados encontrados são apresentados a seguir:

\begin{tabular}{lcccc}
\hline \multicolumn{5}{c}{ Parâmetros } \\
\hline Anos & 1995 & 1996 & 1997 & 1998 \\
Horas de trabalho & 12.139 & 14.928 & 18.792 & 15.907 \\
Eficiências de Campo (\%) & 50,83 & 52,49 & 48,42 & 55,70 \\
Capacidade Operacional $\left(\mathrm{t} . \mathrm{h}^{-1}\right)$ & 21,39 & 20,80 & 23,62 & 23,25 \\
Consumo de Combustivel $\left(1 . \mathrm{t}^{-1}\right)$ & 1,19 & 1,23 & 1,19 & 1,20 \\
Consumo de Combustivel $\left(1 . \mathrm{h}^{-1}\right)$ & 25,48 & 25,53 & 28,17 & 27,97 \\
Custos (US\$.t & - & - & - & 1,56 \\
\hline
\end{tabular}

O Boletim Técnico $(1998)^{3}$ apresenta resultados da coleta de dados feita em 29 usinas na safra 97/98. Os levantamentos abrangeram 96 máquinas colhedoras da marca Brastoft, modelos 7000 e 7700. Os valores de desempenho e custos obtidos são apresentados a seguir:

\begin{tabular}{lc}
\hline \multicolumn{1}{c}{ Parâmetros } & Valor \\
\hline Jornada de Trabalho( $\mathrm{h})$ & 12,4 \\
Cana Colhida $\left(\mathrm{t} . \mathrm{h}^{-1}\right)$ & 33,8 \\
Consumo de Combustivel $\left(1 . \mathrm{h}^{-1}\right)$ & 35,0 \\
Consumo de Combustivel $\left(1 . \mathrm{t}^{-1}\right)$ & 1,08 \\
Consumo de Óleo Hidráulico $\left(1 . \mathrm{h}^{-1}\right)$ & 0,53 \\
Consumo de Óleo Hidráulico $\left(1 . \mathrm{t}^{-1}\right)$ & 0,017 \\
Custos (US\$.t $\left.\mathrm{t}^{-1}\right)$ & 1,193 \\
\hline
\end{tabular}

Kronka \& Monteiro (1999) realizaram estudos na Usina Iturama, Estado de São Paulo, na safra 98/99 com o objetivo de verificar a viabilidade operacional e econômica da colhedora Brastoft 7700, em canaviais sem queima prévia. A colhedora operou com $64,64 \%$ de eficiência, jornada de trabalho de 15,48 horas por dia, sendo colhidas

\footnotetext{
${ }^{3}$ Boletim Técnico: resultado da coleta de dados de 96 colhedoras Brastoft, na safras $97 / 98$. Piracicaba,SP. Mar./1998
} 
133.834 toneladas por safra. A capacidade operacional encontrada foi de $37,67 \mathrm{t}^{-1} \mathrm{~h}^{-1} \mathrm{O}$ custo da colheita mecanizada obtida foi de US\$. $\mathrm{t}^{-1} 2,44$ de cana colhida.

Strini Jr. (1999) apresentou valores de desempenho econômico e operacional da colheita mecânica da cana-de-açúcar, por colhedora Austoft 7700 , em canaviais sem queima prévia, na Usina Junqueira, no Estado de São Paulo na safra 98/99. Os valores de desempenho obtidos são apresentados a seguir:

\begin{tabular}{lc}
\hline \multicolumn{1}{c}{ Parâmetros } & Valor \\
\hline Indice de Matéria Estranha Mineral (\%) & 0,5 \\
Perdas Totais ( \%) & 6,98 \\
Capacidade Operacional $\left(\mathrm{t} . \mathrm{h}^{-1}\right)$ & 32,28 \\
Consumo de Combustível $\left(1 . \mathrm{h}^{-1}\right)$ & 38,38 \\
Consumo de Combustível $\left(1 . \mathrm{t}^{-1}\right)$ & 1,25 \\
Custo Operacional (US\$.t & 1,23 \\
Custo/hora (US\$) & 39,67 \\
\hline
\end{tabular}

Cury (1999), analisando desempenho operacional e econômico de duas colhedoras Brastoft, utilizadas na usina na Usina Santa Helena, no Estado de São Paulo, na safra 98/99, em canaviais sem queima prévia, encontrou os seguintes resultados: eficiência de campo 64,45\%, consumo de combustível $0,791 . \mathrm{t}^{-1}$, consumo de óleo hidráulico 7,62 ml.t. $\mathrm{t}^{-1}$, capacidade operacional 45,80 t.h $\mathrm{h}^{-1}$, custos variáveis em torno de US $\$ . t^{-1} 0,52$. 


\section{MATERIAL E MÉTODOS}

Para este estudo, foram utilizados os seguintes material e métodos:

\subsection{Material}

As determinações de campo foram conduzidas no período compreendido entre $7 \mathrm{e}$ 17 de julho de 1998, na Fazenda Porto Velho, pertencente à Usina da Barra, localizada no Município de Barra Bonita, Estado de São Paulo, situada nas seguintes coordenadas geográficas: $22^{0} 35^{\prime} 24^{\prime \prime}$ de Latitude Sul, $48^{0} 38^{\prime} 09^{\prime \prime}$ de Longitude Oeste, com 546 metros de altitude. A área foi identificada como talhão 9, zona 1.258, possuindo 8,61 ha, com $2 \%$ de declividade, e solo classificado como Latossolo Roxo-argiloso, sendo o talhão sistematizado para a colheita mecânica. A variedade utilizada foi a RB 83-5089, que apresenta alta capacidade produtiva, colmos bastante longos, porte ereto, resistente à ferrugem, recomendada para colheita em final de safra (Arizono et al., 1993), em terceiro corte, plantada no espaçamento entre fileira de $1,40 \mathrm{~m}$.

Os instrumentos, materiais e equipamentos utilizados no ensaio foram: cronômetros, célula de carga com acurácia de mais ou menos $0,5 \mathrm{kgf}$, paquímetro, latas de alumínio com tampa, fita crepe, sacos plásticos, estacas, piquetes, trena de 20 metros, etiquetas, corda de nylon, tambores metálicos de 200 litros, rádiotransmissores, facões, lonas plásticas, tratores com carretas para transbordo, caminhões para transporte da matériaprima, caminhão-bombeiro, comboios de manutenção e de abastecimento. 


\subsubsection{Máquina colhedora}

Origem - Nacional.

Ano de fabricação - 1997.

Valor de aquisição - US\$ 267.000,00.

Horas de trabalho registradas pelo odômetro - 900 horas.

Motor do ventilador extrator primário $1400 \mathrm{rpm}$, massa de ar saída $14,4 \mathrm{~m} . \mathrm{s}^{-1}$

Motor do ventilador extrator secundário $1500 \mathrm{rpm}$, massa de ar saída $18,3 \mathrm{~m} . \mathrm{s}^{-1}$

Motor - Scania 325 HP.

Transmissão - Hidrostática.

Cortadores de Pontas - Discos recolhedores, com tambor central de facas.

Divisores de linha - Cones espiralados.

Cortadores de base - Discos duplos, com 5 facas por unidade, de acionamento hidráulico e reversível

Rolos alimentadores - Acionamento hidráulico e reversível, com 6 rolos superiores e 6 rolos inferiores.

Facões Picadores - Acionamento hidráulico, tipo tambor rotativos, com 4 lâminas substituíveis.

Extratores - Acionamento hidráulico, com 3 pás por ventilador e descarga direcional.

Elevadores - Acionamento hidráulico, com 2 motores hidráulicos e giro de $160^{\circ}$.

Freios - Acionamento automático com a parada do motor, a discos operados hidraulicamente e de estacionamento manual.

Rodado - Esteiras 


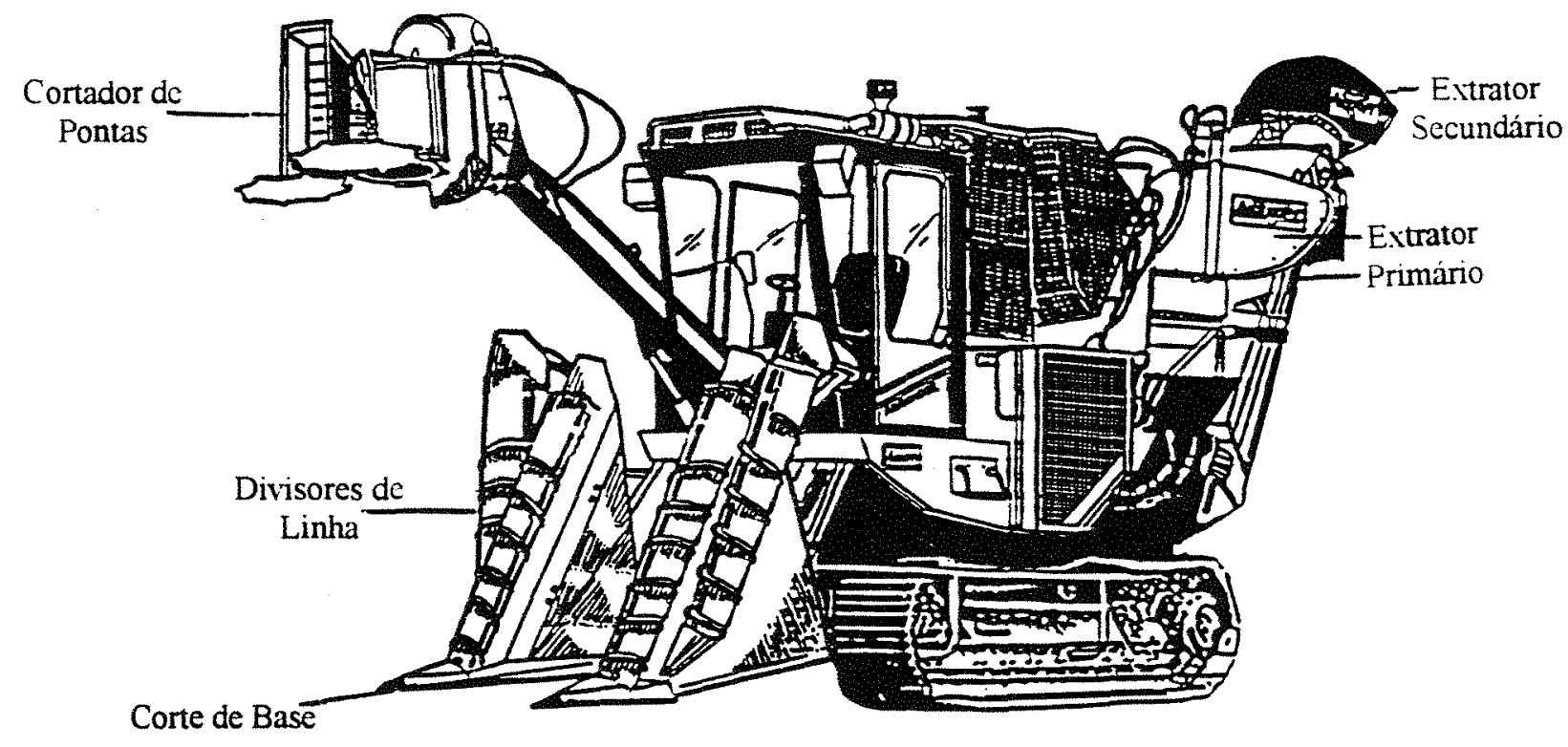

Figura 1. Esquema da máquina utilizada.

\subsection{Métodos}

As determinações de campo foram efetuadas com base na metodologia proposta por Ripoli (1996), que recomenda, primeiramente, a caracterização das condições de campo. Em seguida, o desempenho operacional e a qualidade do processamento, abrangendo as seguintes determinações:

\section{2.1. Porte do canavial}

$\mathrm{O}$ estado de acamamento ou porte do canavial foi avaliado utilizando um gabarito de forma triângulo-retangular, conforme ilustra a Figura 2. 
Foram tomadas 12 áreas ao acaso no talhão em estudo, posicionando-se o gabarito sobre o solo ao longo da fileira de cana, procedendo-se à contagem e às anotações do número de colmos eretos, acamados e deitados, mostrado na Figura 3.

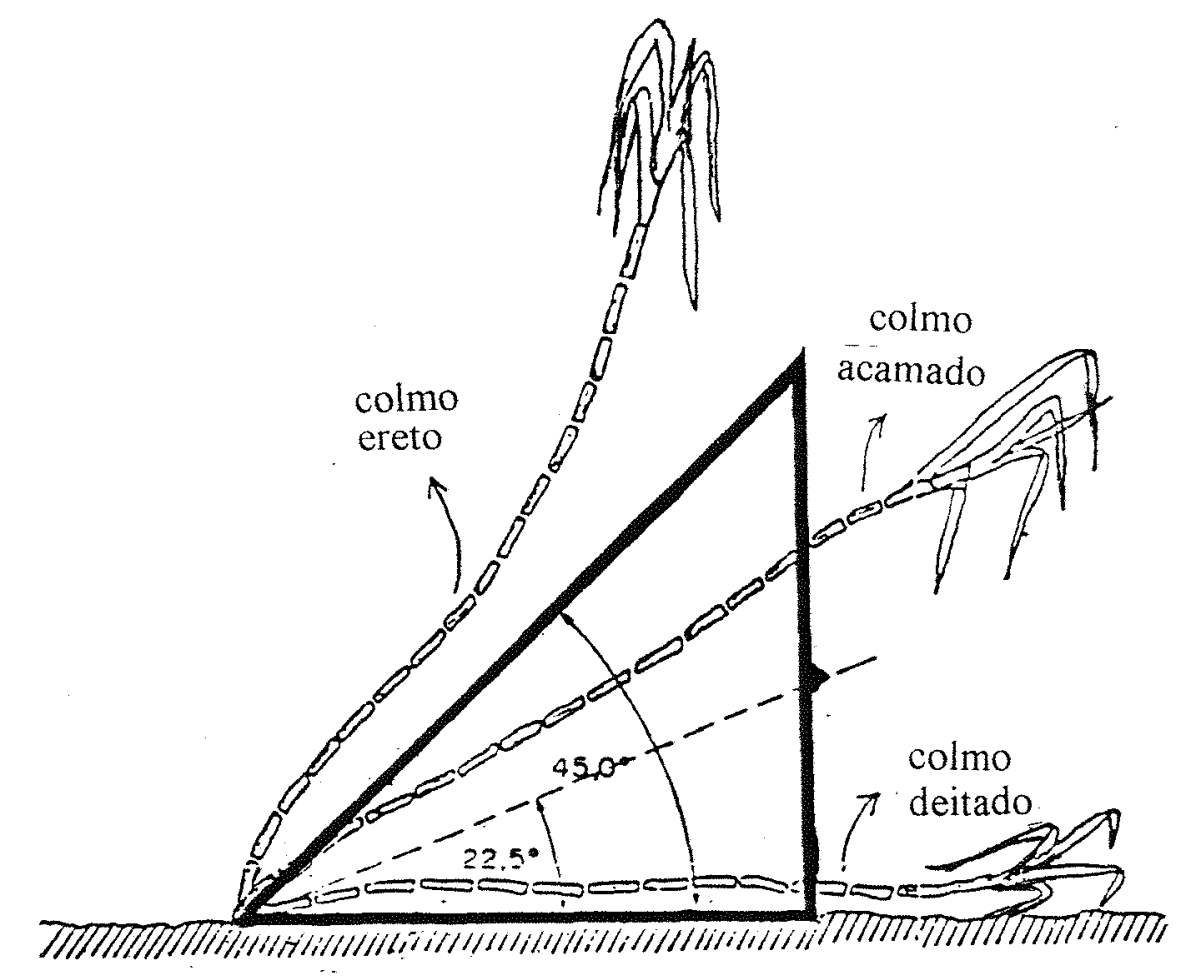

Figura 2. Gabarito utilizado para determinação do porte do canavial.

Fonte: Ripoli, (1977).

\subsubsection{Densidade média dos colmos e matéria estranha vegetal}

Para essas determinações, foram demarcados no talhão 12 áreas ao acaso de 4,2 $\mathrm{m}^{2}$, sendo cada uma de 3,0 metros ao longo de fileira de colmos por 1,4 metros entre fileiras, coletando-se toda a massa vegetal existente (colmos, folhas verdes, palhas, ponteiros). 


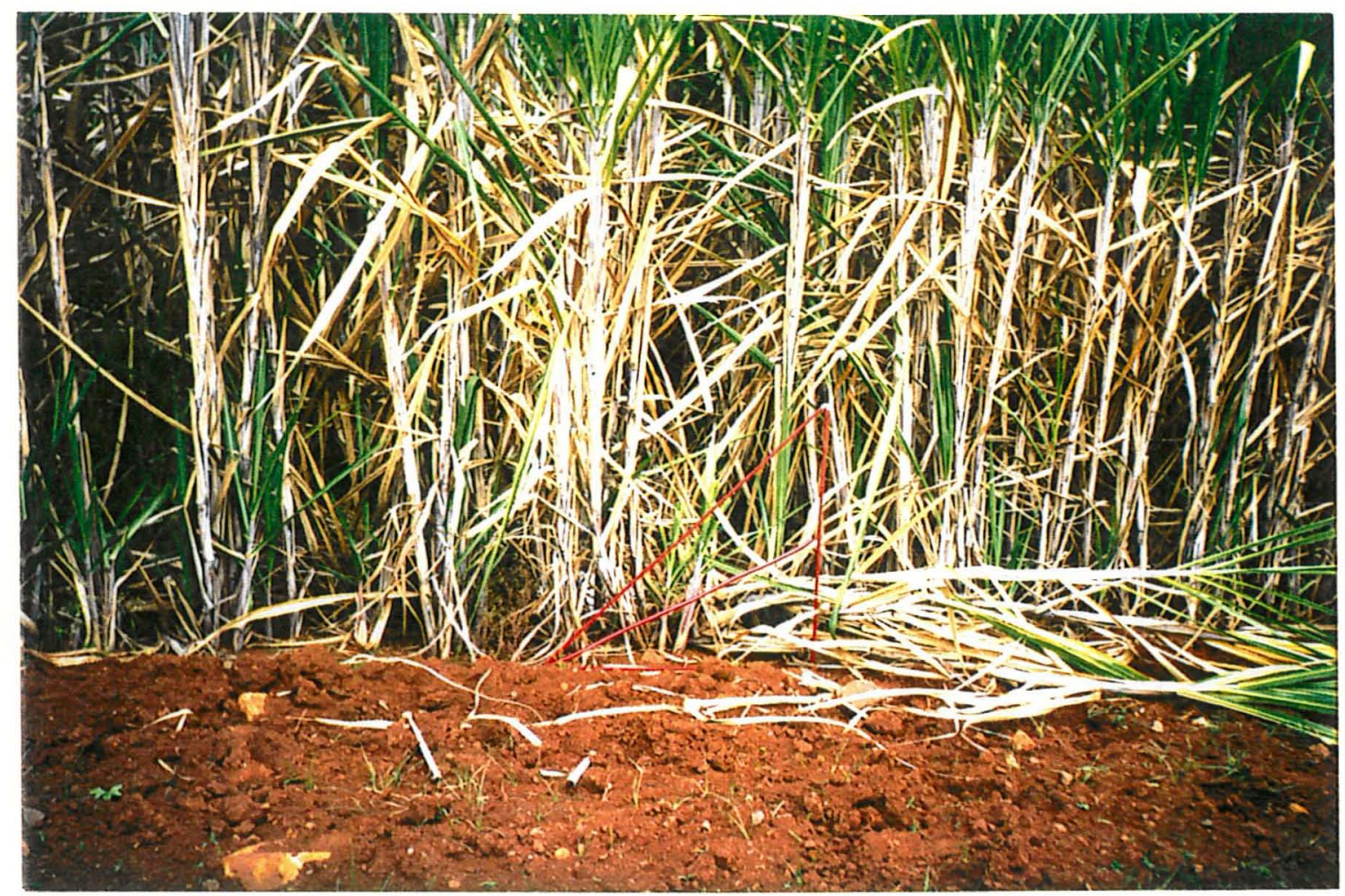

Figura 3. Utilização do gabarito para determinação do porte do canavial.

Posteriormente, realizou-se a separação de toda a.massa vegetal, como mostra a Figura 4. Após esta separação, procedeu-se à contagem do número de colmos. Em seguida determinou-se o peso de folhas verdes, palhas, ponteiros e colmos, para se estimar a produtividade agrícola e a biomassa aérea total do canavial (Figura 5). Para a determinação de cada fração constituinte da biomassa nas repetições, calculou-se a média aritmética e o desvio padrão. 


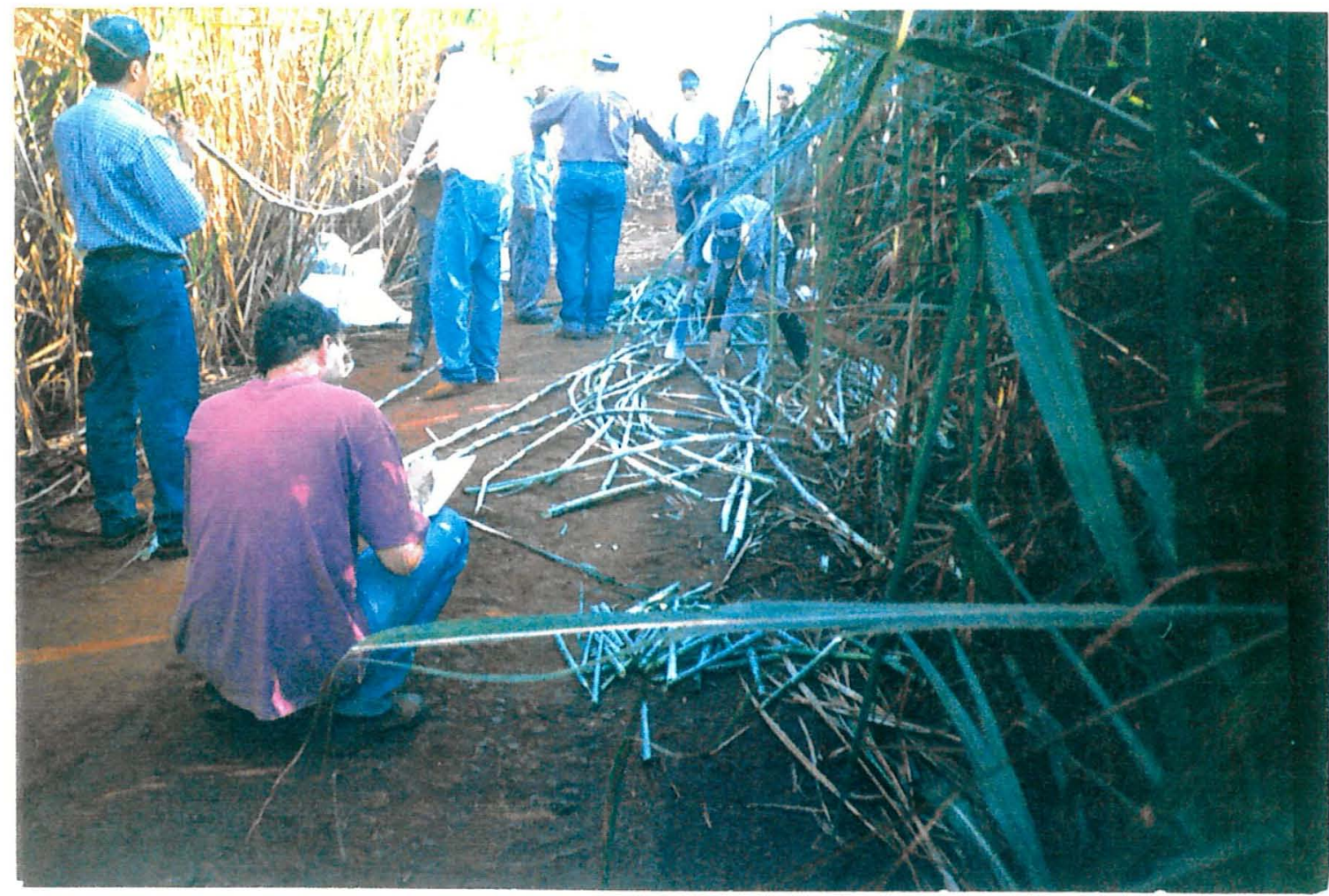

Figura 4.Coleta de amostra para a caracterização do canavial. Separação de suas frações: colmos, folhas verdes, ponteiros e palhas.

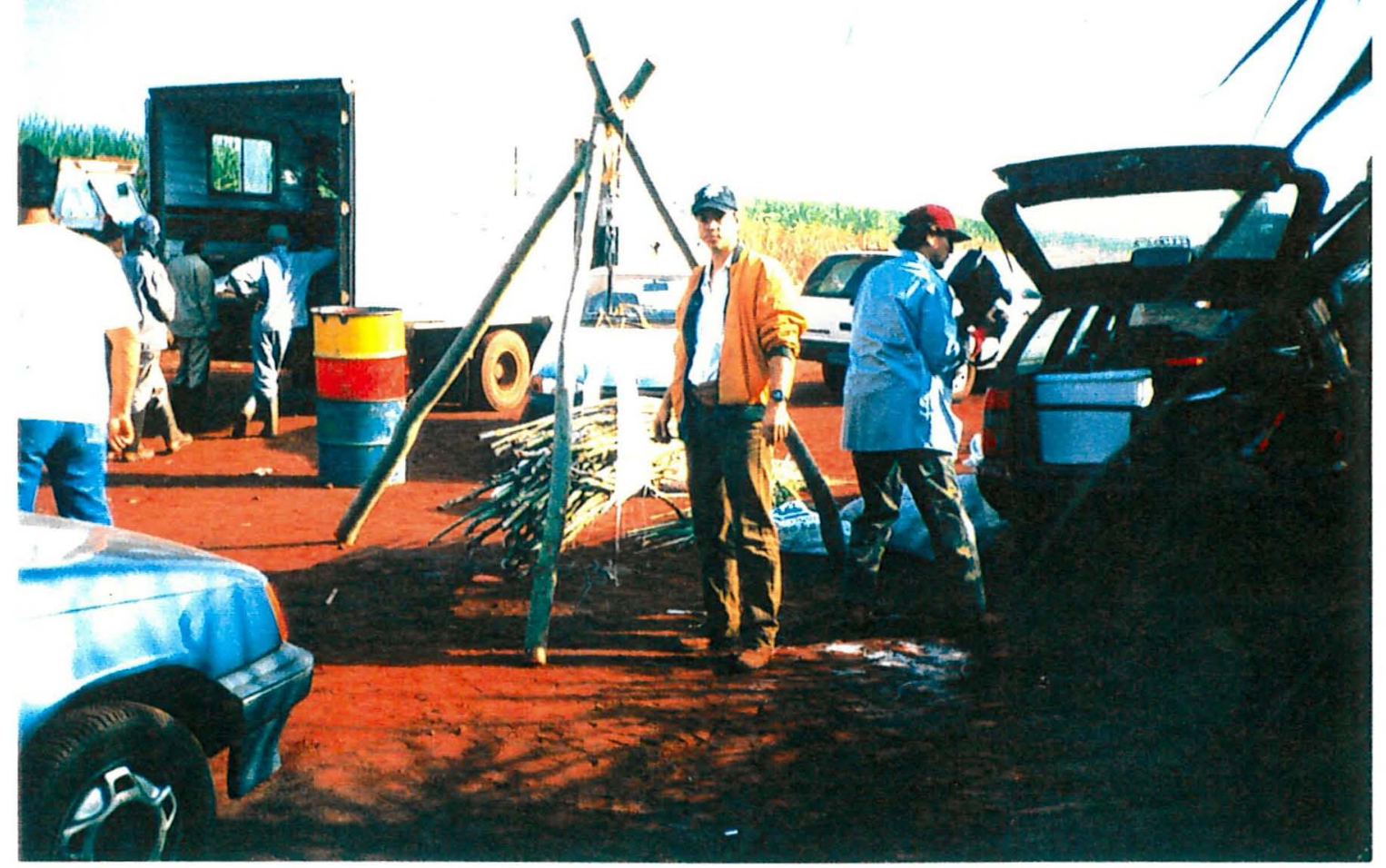

Figura 5. Determinação ponderal dos colmos recolhidos em dada amostra. 


\subsubsection{Comprimento médio dos colmos}

Os colmos industrializáveis coletados nas 12 áreas foram medidos $\mathrm{e} 0$ comprimento, determinado por média aritmética. Neste caso, deve-se calcular o desvio padrão e o coeficiente de variação.

\subsubsection{Teor de água no solo}

Para a determinação do teor de água no solo, coletou-se ao acaso quatro amostras de solo próximas à fileira de plantio, logo após a passagem da máquina em cada repetição, no perfil do solo de 0,0 a $0,10 \mathrm{~m}$ de profundidade. As amostras foram colocadas em latas de alumínio e lacradas com fita adesiva para impermeabilização. $\mathrm{O}$ teor de água foi determinado pelo método gravimétrico, após secagem em estufa a $105^{\circ} \mathrm{C}$ por 24 horas, pelo método proposto por Kiehl (1979).

\subsubsection{Granulometria do solo}

A granulometria do solo foi determinada pelo método proposto por Steel \& Bradfield (1934). As amostras utilizadas foram as mesmas coletadas para a determinação do teor de água.

\subsubsection{Grau de maturação da cultura}

O grau de maturação da cultura foi determinado no laboratório da unidade industrial da Usina da Barra, pelo método proposto por Zarpelon et al. (1978).

\subsubsection{Desempenho operacional da colhedora}

A máquina foi avaliada operando em quatro diferentes velocidades: $\mathrm{V} 1=1,5$ $\mathrm{km} \cdot \mathrm{h}^{-1}, \mathrm{~V} 2=3,0 \mathrm{~km} \cdot \mathrm{h}^{-1}, \mathrm{~V} 3=5,0 \mathrm{~km} \cdot \mathrm{h}^{-1} \mathrm{e} \mathrm{V4}=7,0 \mathrm{~km} \cdot \mathrm{h}^{-1}$, com quatro repetições por 
velocidade, totalizando 16 determinações. O ajuste dos níveis de velocidade durante as determinações exigiu a realização de testes preliminares, onde houve a necessidade de se demarcar as respectivas posições da alavanca do acelerador da máquina em estudo.

Respeitou-se uma bordadura de 10 metros em cada lado do talhão. A máquina foi regulada e ajustada para que se obtivesse o máximo do seu potencial em termos de desempenho para cada velocidade estudada.

Cada repetição correspondeu a uma distância de 100 metros da fileira de plantio. Ao final de cada repetição, a máquina era parada em seu deslocamento, porém os mecanismos de fracionamento dos colmos, a limpeza da matéria-prima, a elevação e o descarregamento do material permaneciam em movimento até processar o material colhido ao longo da fileira ensaiada. No momento em que se encerrava o processamento do material colhido, anotava-se o consumo de combustível. A cana colhida na fileira de 100 metros era descarregada da carreta de transbordo aos veículos, que transportavam o material colhido para a Usina, onde eram feitas as pesagens da matéria-prima colhida em cada repetição. Nas carretas de transbordos existiam dois tambores com capacidade de 100 litros ou $0,1 \mathrm{~m}^{3}$ cada um, coletando amostras para as determinações dos valores referentes a tamanho dos rebolos, índice de cisalhamento dos rebolos, análises tecnológicas da matéria-prima e determinação da matéria estranha. 


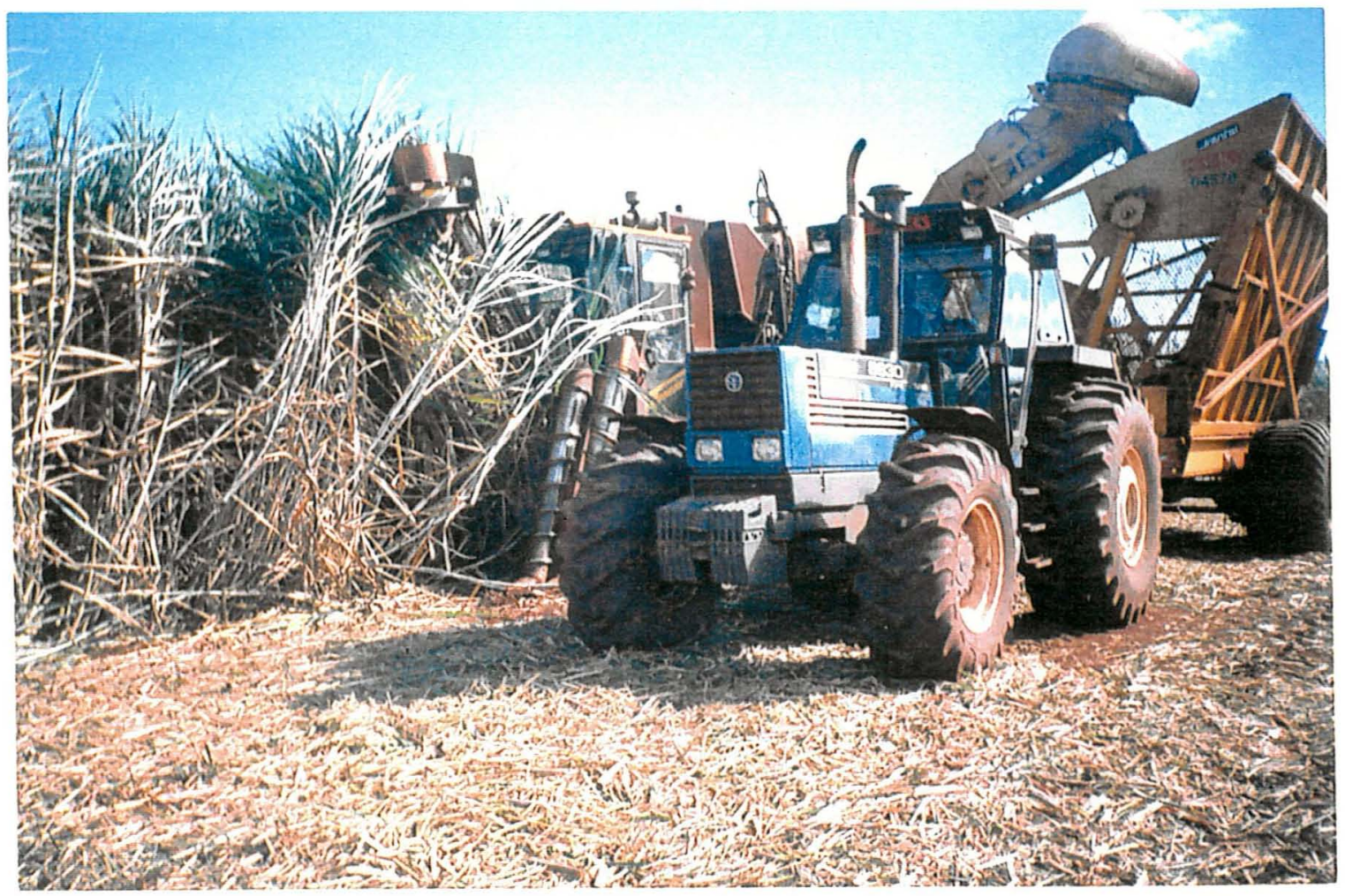

Figura 6. Máquina colhendo em uma fileira (repetição), com a unidade de transbordo que continha os tambores para amostra da qualidade da matéria-prima.

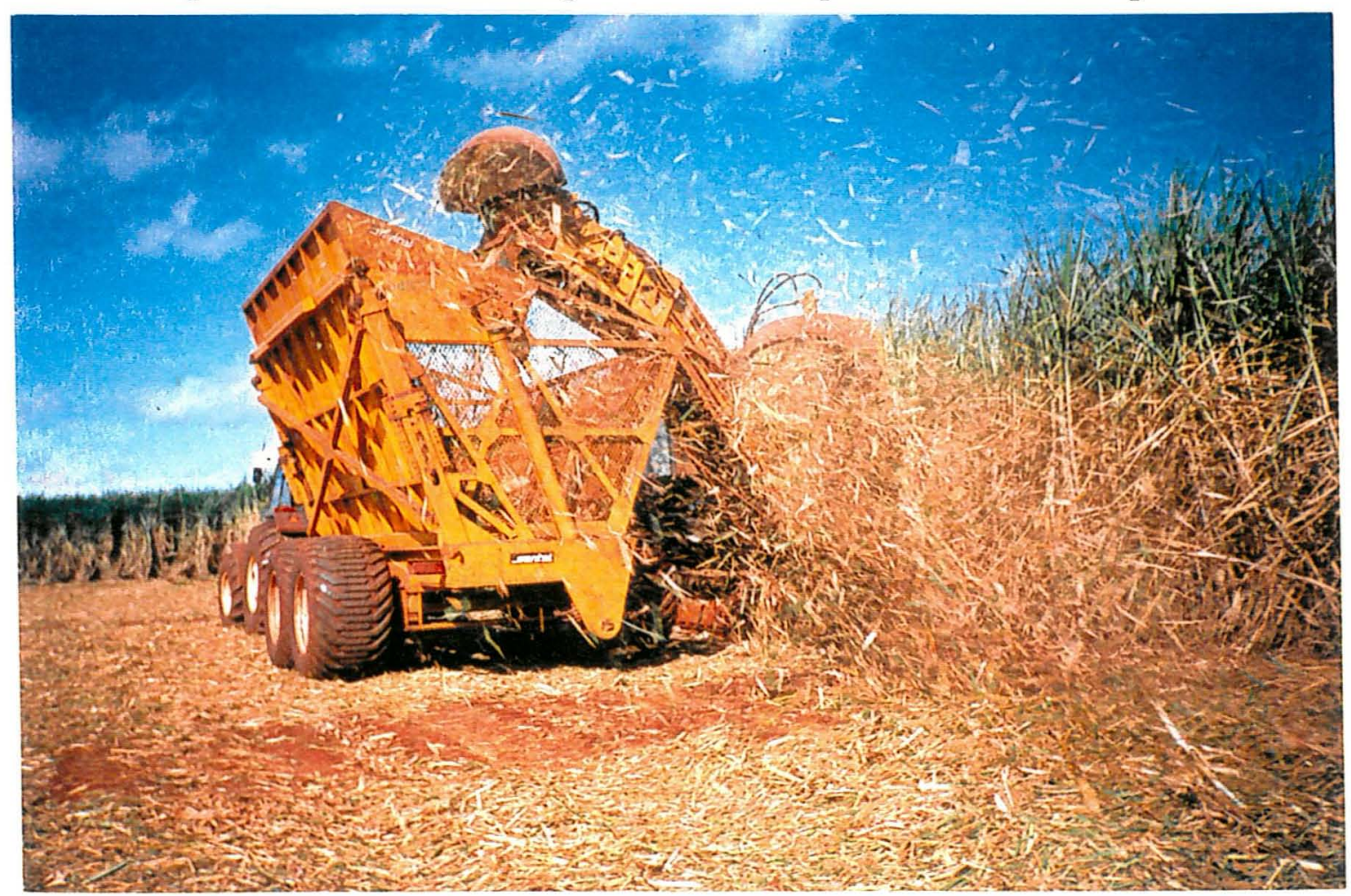

Figura 7. Resultado da ação do sistema de limpeza da colhedora. 
Após a passagem da colhedora na fileira de 100 metros, demarcaram-se duas áreas de $12,6 \mathrm{~m}^{2}$, sendo constituídas de 3,0 metros de comprimento ao longo da fileira de plantio, e 4,2 metros de largura para a determinação das perdas no campo, como apresenta o esquema da Figura 8.

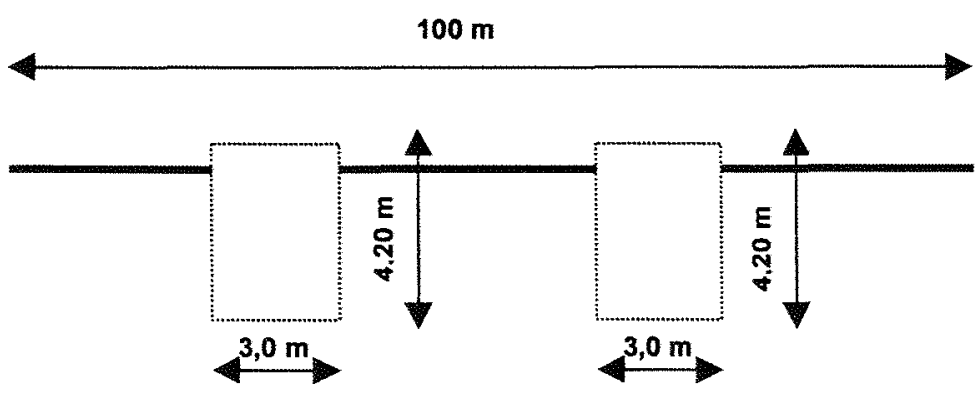

Figura 8. Esquema da área demarcada para a coleta das perdas de matéria-prima.

Após a demarcação, recolheu-se em sacos plásticos toda a massa vegetal encontrada na área. Os restos de colmos nas soqueiras deixados pela máquina foram cortados rente ao solo, e recolhidos em sacos plásticos, como mostra a Figura 9. Estes foram etiquetados e transportados para fora da área de ensaio. Em seguida, separou-se todo o material coletado sobre o terreno dentro da área amostral, ou sejam: folhas verde, palhas, rebolos, cana dilacerada, tocos, e raízes (Figura 10). Posteriormente, pesaram-se todas as frações separadamente para a determinação das perdas de matéria-prima no campo. 


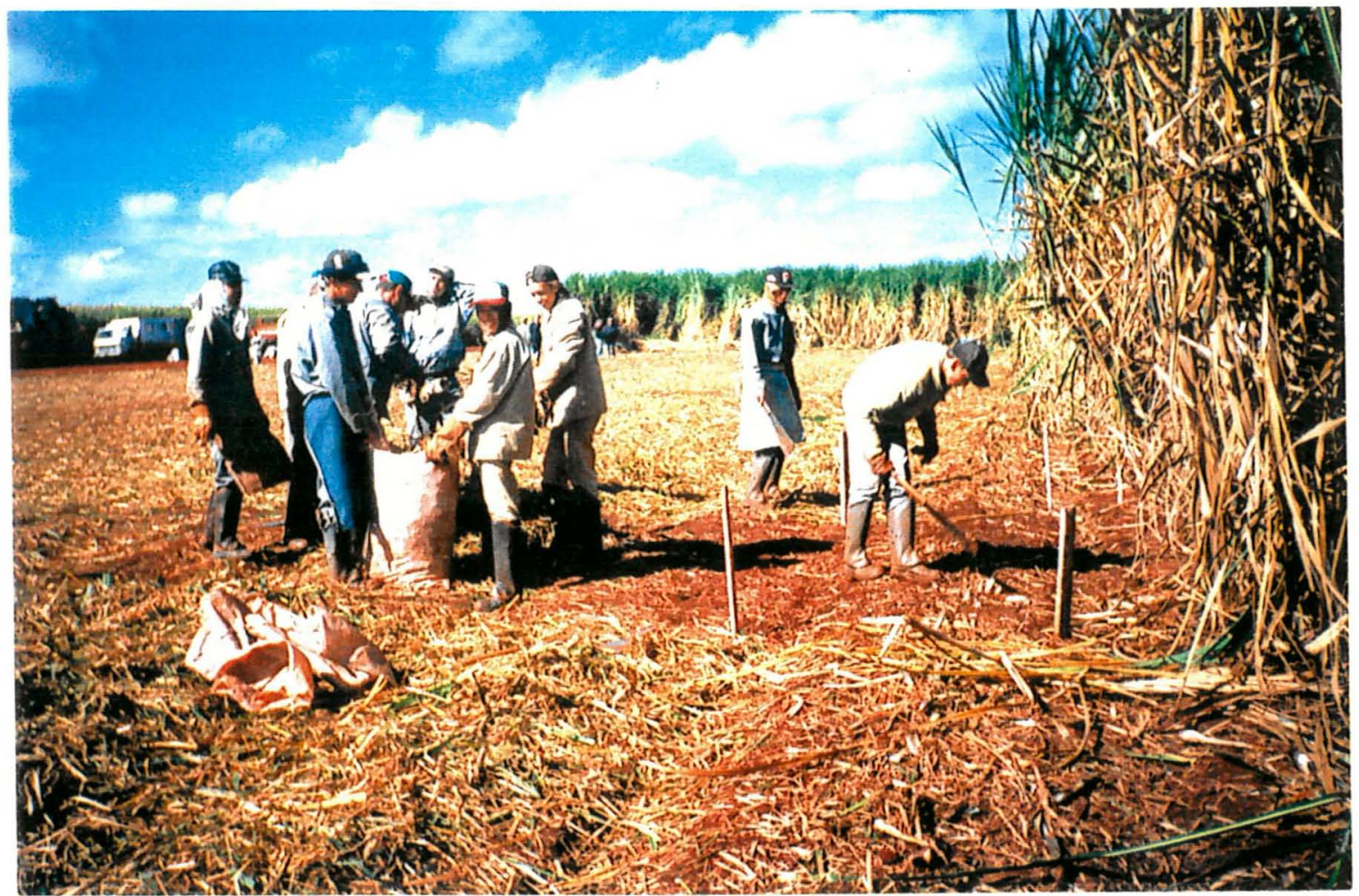

Figura 9. Recolhimento das perdas de matéria-prima em uma área de amostragem.

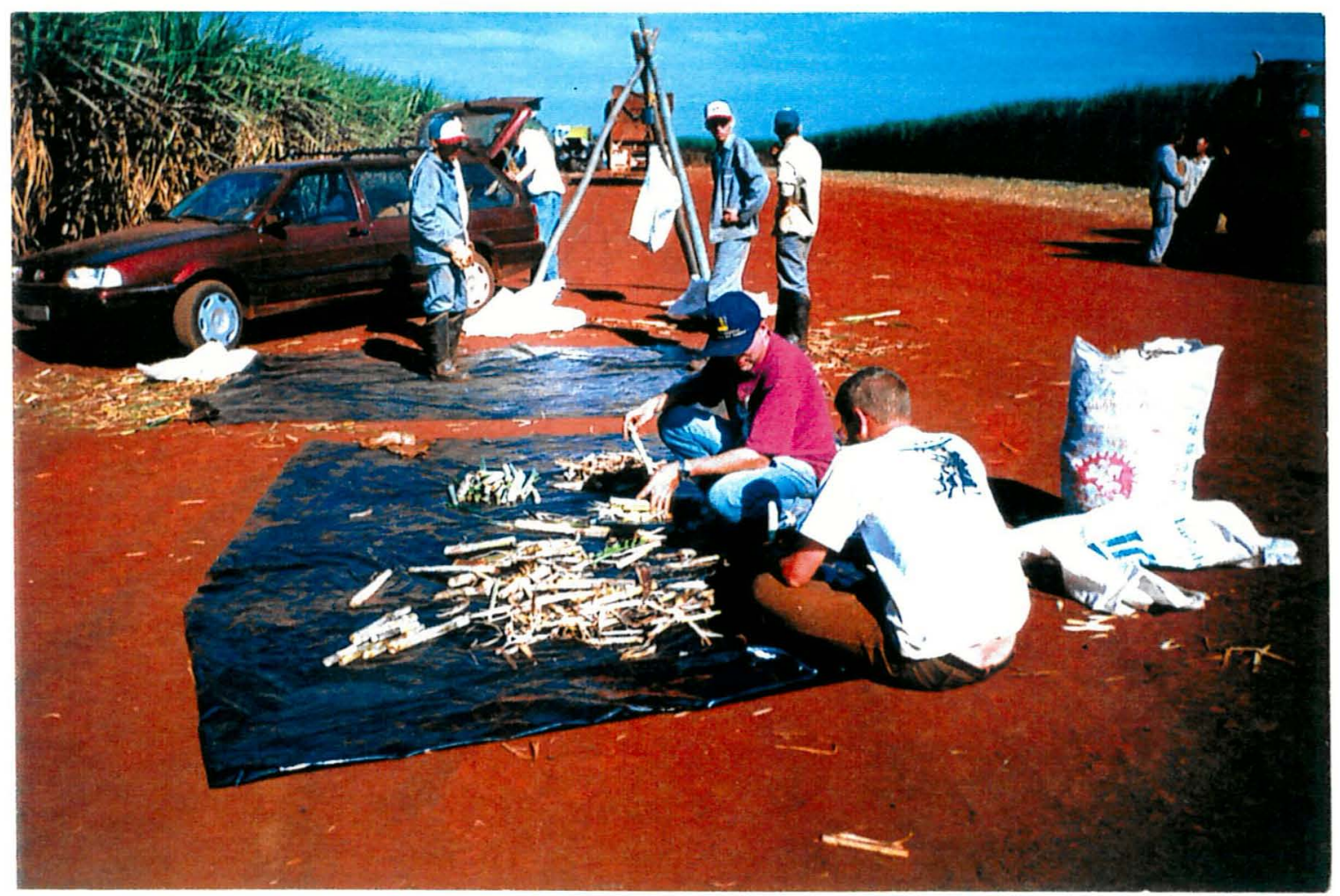

Figura 10. Separação da matéria-prima contida na massa vegetal em uma área de amostragem de perdas e as respectivas determinações ponderais. 


\subsubsection{Capacidade Efetiva bruta $-\mathrm{CE}_{\mathrm{b}}$}

Considerada como sendo a quantidade de matéria-prima lançada no veículo de transporte pela máquina na unidade de tempo na parcela padrão de ensaio, calculada pelas equações:

$$
\begin{aligned}
& \mathrm{CE}_{\mathrm{b}}\left(\mathrm{kg} \cdot \mathrm{s}^{-1}\right)=\mathrm{W}_{\mathrm{e}}(\mathrm{kg}) / \mathrm{T}_{\mathrm{e}}(\mathrm{s}) \\
& \mathrm{CE}_{\mathrm{b}}\left(\mathrm{t} \cdot \mathrm{h}^{-1}\right)=\mathrm{CE}_{\mathrm{b}}\left(\mathrm{kg} \cdot \mathrm{s}^{-1}\right) \cdot 3,6
\end{aligned}
$$

Onde:

$\mathrm{CE}_{\mathrm{b}}=$ Capacidade Efetiva Bruta;

$\mathrm{W}_{\mathrm{e}}=$ Massa de produto colhido e colocado no veículo de transporte durante $\mathrm{o}$ ensaio;

$T_{e}=$ Tempo decorrido, cronometrado no ensaio, no recolhimento da massa $W_{e}$.

\subsubsection{Capacidade Operacional $-\mathrm{CO}_{\mathrm{p}}$}

A Capacidade Operacional em cada velocidade foi obtida a partir dos dados da Capacidade Efetiva Bruta correspondente, multiplicadas pelas Eficiência de Campo de $45,55,65$ e $75 \%$, em decorrência de serem as faixas de eficiências de campo mais freqüentes nas Usinas do Estado de São Paulo, sendo determinada pela equação:

$\mathrm{CO}_{\mathrm{p}}\left(\mathrm{t}^{-h^{-1}}\right)=\mathrm{CE}_{\mathrm{b}}$. Ef. $(\%) / 100$

Onde:

$\mathrm{CO}_{\mathrm{p}}=$ Capacidade Operacional.

$\mathrm{CE}_{\mathrm{b}}=$ Capacidade Efetiva bruta.

$\mathrm{Ef}(\%)=$ Eficiência de Campo.

\subsubsection{Eficácia de Manipulação - EM (\%)}

Calculada como sendo a relação entre a quantidade (tc) de rebolos de colmos colocados na unidade de transporte, e a quantidade $(\mathrm{tC})$ de colmos existente na fileira de plantio, determinada pela equação: 
$\mathrm{EM}(\%)=(\mathrm{tc} / \mathrm{tC}) \cdot 100$

onde:

EM (\%) = Eficácia de Manipulação.

Em colhedoras combinadas (tC) é função do material não colhido e não carregado, constituindo-se em perdas.

\subsubsection{Perdas de matéria-prima no campo}

Determinada como sendo a matéria-prima industrializável que permanece no campo, após a passagem da máquina. A perda total (\%) foi obtida pela a soma das perdas de: Colmos e ou suas frações (\%); Rebolos inteiros (\%); Frações de rebolos (\%); e Rebolos na soqueira (\%). As raízes arrancadas após a passagem da máquina foram coletadas, pesadas, expressas em kg.ha ${ }^{-1}$.

\subsubsection{Capacidade Efetiva Líquida - $\mathrm{CE}_{1}$}

Determinada pela Capacidade Efetiva Bruta multiplicada pela Eficácia de Manipulação, calculada pela equação:

$\mathrm{CE}_{1}\left(\mathrm{t} \cdot \mathrm{h}^{-1}\right)=\mathrm{CE}_{\mathrm{b}}\left(\mathrm{t} \cdot \mathrm{h}^{-1}\right) \cdot \mathrm{EM}(\%) / 100$

Onde:

$\mathrm{CE}_{1}=$ Capacidade Efetiva líquida.

\subsubsection{Consumo de combustível}

Foi determinado pela quantidade de combustível consumido pela colhedora, quando seus órgãos ativos atuavam diretamente na fileira de ensaio. Para a mensuração, foi utilizado um FUEL FLOWMETER da marca CATERPILLAR (Figura 11). 


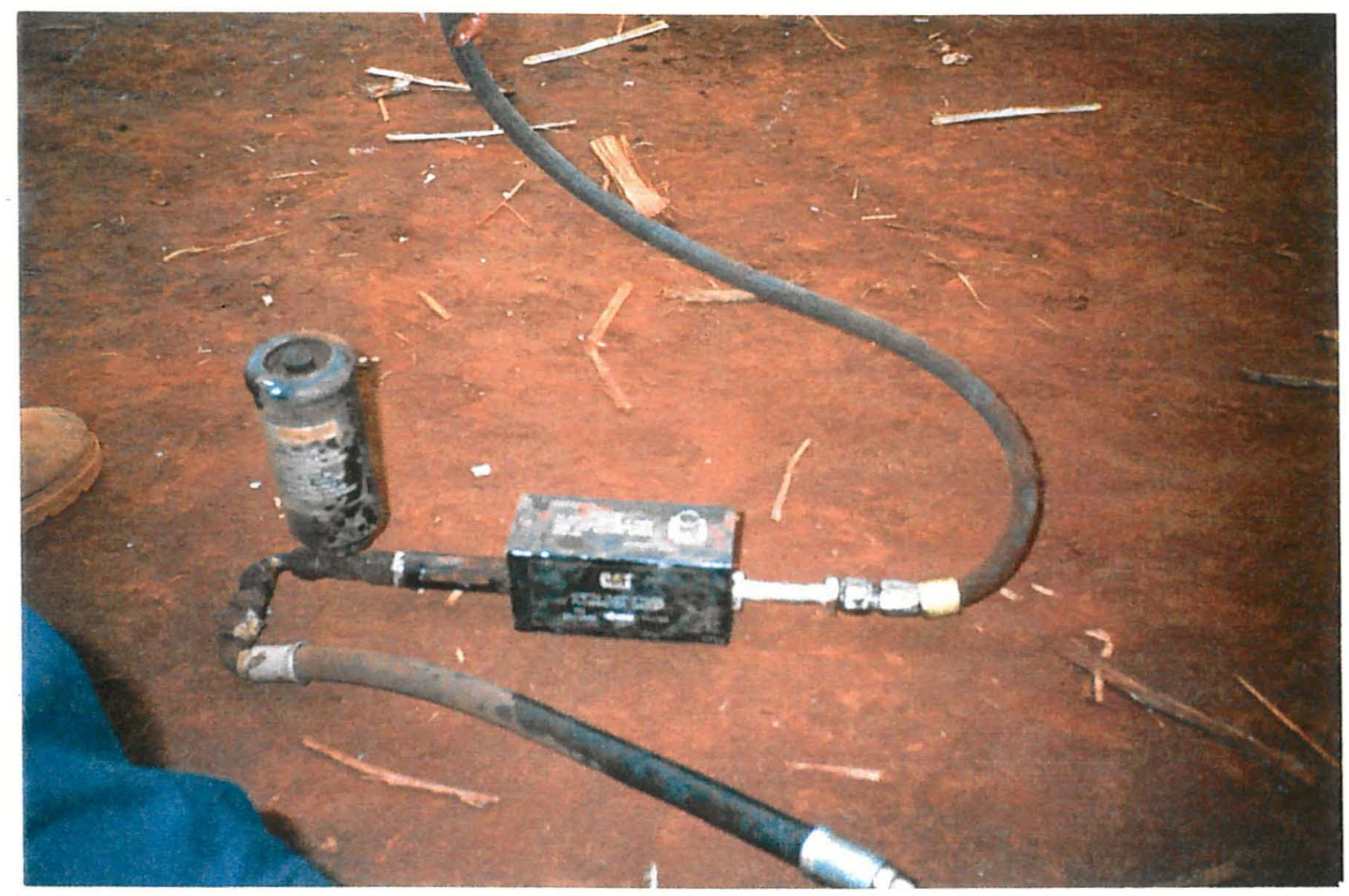

Figura 11. Medidor de consumo de combustível.

\subsection{5 Índice de Matéria Estranha na matéria-prima.}

Determinada como sendo a quantidade de matérịa estranha que acompanha a matéria-prima industrializável no veículo de transporte, constituída dos seguintes índices:

Índice de Ponteiros IP (\%) - Quantidade em peso de ponteiros livres (PL) e de ponteiros aderidos $(\mathrm{PA})$ aos rebolos, na quantidade $(\mathrm{C})$, correspondente à matéria-prima na unidade de transporte, calculado pela equação:

$$
\mathrm{IP}(\%)=((\mathrm{PL}+\mathrm{PA}) / \mathrm{C}) .100
$$

Índice de Folhas IF (\%) - Relação entre a quantidade, em peso de folhas verdes, (fv) e a quantidade (C) de matéria-prima na unidade de transporte, calculado por:

$$
\mathrm{IF}(\%)=(\mathrm{fv} / \mathrm{C}) \cdot 100
$$


Índice de Palhas IP (\%) - Calculado como sendo a relação entre a quantidade, em peso, de palhas $(\mathrm{P})$ e a quantidade $(\mathrm{C})$ de matéria-prima na unidade de transporte, expressa por:

$$
\operatorname{IP}(\%)=(\mathrm{P} / \mathrm{C}) .100
$$

Índice de Raízes IR (\%) - Expressa em porcentagem a massa de raízes (R) contida na carga $(\mathrm{C})$, calculada por:

$\mathrm{IR}(\%)=(\mathrm{R} / \mathrm{C}) .100$

Índice da Matéria Estranha Vegetal IV (\%) - Representada pela soma das massas dos indices de ponteiros, folhas verdes, palhas e raízes que acompanham os colmos industrializáveis, na unidade de transporte, expressas por:

$$
\operatorname{IV}(\%)=\operatorname{IP}(\%)+\operatorname{IF}(\%)+\operatorname{IP}(\%)+\operatorname{IR}(\%)
$$

Índice de Matéria Estranha Mineral IM (\%) - Obtido pela relação entre a quantidade em massa $(\mathrm{T})$ de terra e a quantidade $(\mathrm{C})$ massa de rebolos, na unidade de transporte, calculada por:

$$
\operatorname{IM}(\%)=(\mathrm{T} / \mathrm{C}) .100
$$

Índice de Matéria Estranha Total IT (\%) - Determinado pela soma do índice de Matéria Estranha Vegetal - IV (\%), com o índice de Matéria Estranha Mineral - IM (\%), sendo obtido por:

$$
\operatorname{IT}(\%)=\operatorname{IV}(\%)+\operatorname{IM}(\%)
$$

\subsubsection{Qualidade Tecnológica da matéria-prima}

Estas análises foram realizadas nos laboratórios da Usina da Barra, pelo método proposto por Zarpelon et al. (1978), sobre as amostras coletadas em cada parcela de ensaio, analisando-se os seguintes parâmetros: brix do caldo, pol do caldo, pureza do caldo, fibra da cana, pol da cana e terra. 


\subsubsection{Freqüência de comprimento dos rebolos}

Este parâmetro indica a distribuição percentual do comprimento dos rebolos obtidos (Figura12), importante quando se colhe cana para o plantio mecanizado, uma vez que o mecanismo dosador da máquina que faz o plantio é sensível ao comprimento dos rebolos, e para a determinação ótima deste comprimento visando à redução de perdas, matéria estranha, deterioração e transporte de matéria-prima (Vitale \& Domante, 1997). Para esta determinação, coletou-se 20 amostras de cada repetição, medindo-as com uma régua de $0,005 \mathrm{~m}$ de precisão. Em seguida, construiu-se um gráfico de distribuição de freqüência, com intervalos de $0,01 \mathrm{~m}$.

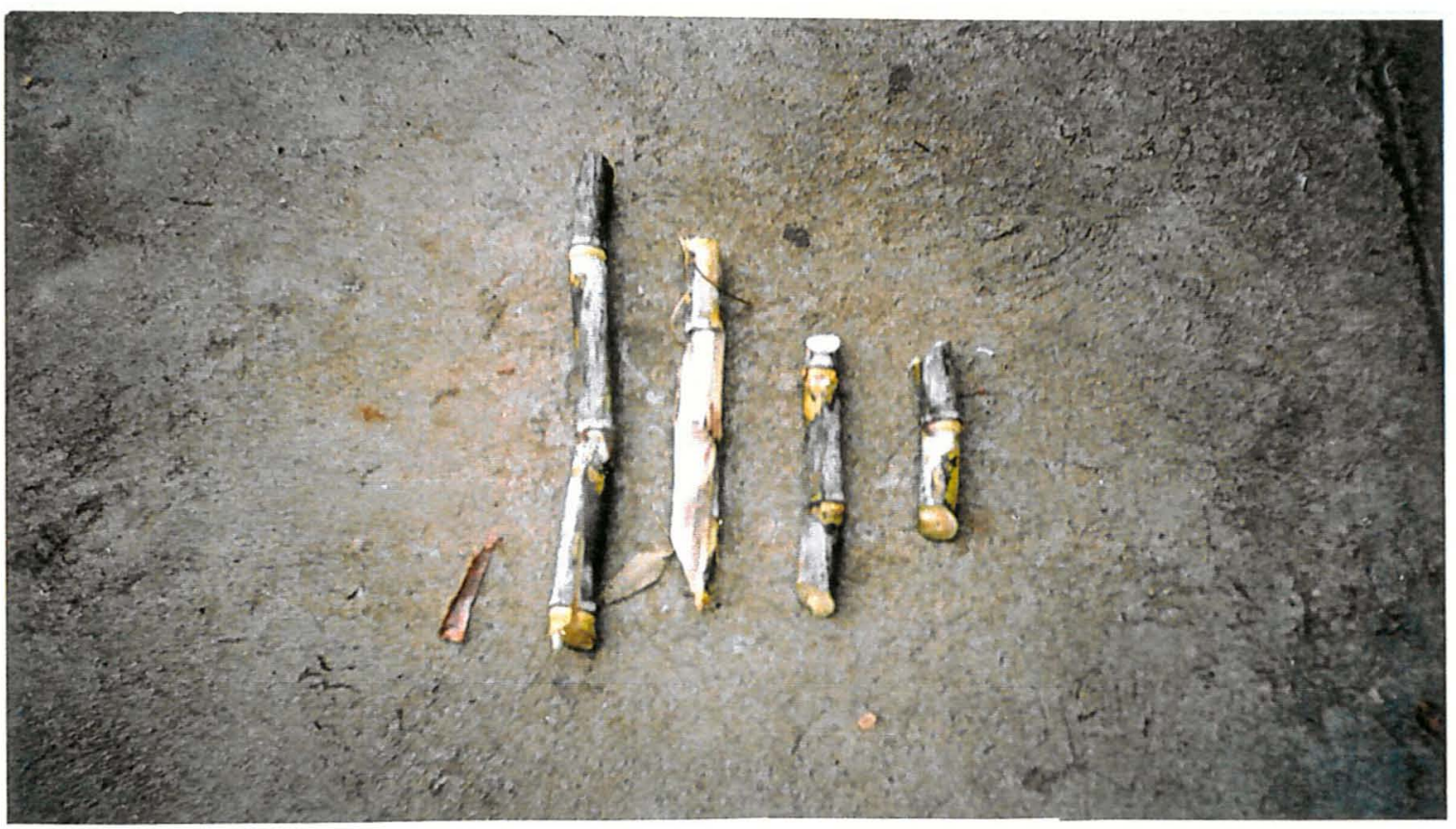

Figura 12. Amostra da variação do comprimento dos rebolos.

\subsubsection{1 Índice de Cisalhamento dos rebolos}

Esta determinação visa avaliar a qualidade do desempenho no mecanismo de corte. Fez-se uma análise visual em amostras com 40 rebolos para cada repetição, 
determinando-se em porcentagem a quantidade de colmos perfeitos, macerados em uma ou em ambas as extremidades.

\subsubsection{Delineamento Estatístico}

O delineamento estatístico utilizado foi o inteiramente casualizado, com um fator (velocidade) e quatro níveis, sendo estes: 1,5, 3,0, 5,0 e 7,0 $\mathrm{km} \cdot \mathrm{h}^{-1} . \mathrm{Em}$ cada nível foram tomadas quatro repetições, totalizando 16 determinações. A análise estatística foi efetuada com o Sistema de Análise Estatística ( SANEST ). Aplicou-se o teste F, ao nível de $5 \%$ de probabilidade, para verificar se as médias apresentaram diferenças significativas. Onde ocorreram diferenças entre as médias, aplicou-se o teste Tukey para as comparações nos níveis de $1 \%$ e $5 \%$ de probabilidade.

\subsubsection{Análise do desempenho econômico}

A análise do desempenho econômico foi realizada pelo método do Custo Anualizado Equivalente (CAE), desenvolvido a partir do conceito da anuidade equivalente para cálculo do custo anual da maquinaria agrícola, descrito e recomendado por Noronha et al. (1991).

Os fundamentos do método CAE, segundo Noronha et al.(1991), consideram todos os custos como variáveis, pois os mesmos são projetados para toda a vida útil da máquina, da aquisição até o descarte. Este método deve ser aplicado visando à compra de novas máquinas, ou ao melhor momento de renovação da frota.

Esta metodologia, caracteriza-se em formar um fluxo de caixa para a colhedora. O fluxo de caixa consiste na diferença dos valores de entrada e saída de recursos econômicos em unidade monetária por unidade de tempo. Esta diferença entre os fluxos de entrada e saída é chamada fluxo líquido, e sobre ele são aplicadas as taxas de desconto, as quais permitem a rentabilidade do investimento (Mialhe \& Carraro Neto, 1993). 
Após a elaboração do fluxo de caixa, calculou-se o custo anualizado equivalente (CAE), segundo equações descritas por Mialhe \& Carraro Neto (1993):

$$
C A E_{\tau}(T)=V P_{T} \cdot F R C
$$

onde:

$\tau=$ taxa unitária de desconto.

$\mathrm{T}=$ tempo de permanência (em anos ) da máquina na empresa.

$\mathrm{VP}_{\mathrm{T}}=$ valor presente, no ano $\mathrm{T}$.

$\mathrm{FRC}=$ fator de recuperação do capital.

Os termos $\mathrm{VP}_{\mathrm{T}}$ e FRC são obtidos por:

$$
V P_{T}=V I+\sum_{i=1}^{T} \frac{D t}{(1-\tau)^{t}}-\frac{V F_{T}}{(1+\tau)^{T}}
$$

e:

$$
F R C=\frac{\tau \cdot(1+\tau)^{T}}{(1+\tau)^{T}-1}
$$

onde:

$\mathrm{VI}=$ valor inicial (máquina nova).

$D t=$ total de despesas no ano $t$.

$\mathrm{t}=$ ano considerado da vida útil.

$\mathrm{VF}_{\mathrm{T}}=$ valor final (de revenda ou de sucateamento).

Foram levados em consideração na parcela formadora do fluxo de caixa da colhedora, segundo Mialhe \& Carraro Neto (1993), os seguintes itens:

- Valor residual (VRT) após um tempo (T) de vida útil;

- Seguros (SE), Alojamento (AL) e Administração (Adm);

- Combustível (CO), Lubrificantes (LU), Óleo Hidráulico $(\mathrm{OH})$ e Comboio de manutenção, abastecimento e carro-pipa (CMAP); 
- Peças de reposição (PR) e Filtros (FI);

- Mão-de-obra do mecânico (MM);

- Mão-de-obra do operador (MO).

Adotou-se o dólar norte-americano como unidade monetária.

a) Depreciação

A depreciação de uma máquina é definida como a perda de valor e da capacidade de trabalho em conseqüência de obsolescência e desgaste material. Foi calculada pelo Método da Linha Reta (Barger et al., 1963), onde a taxa de depreciação anual ou horária é calculada por:

$\mathrm{TD}=\mathrm{VRI}-\mathrm{VRF} / \mathrm{VU}$

onde:

$\mathrm{TD}=$ taxa de depreciação.

$\mathrm{VU}=$ Vida útil.

$\mathrm{VRF}=$ Valor residual final.

$\mathrm{VRI}=$ Valor residual inicial.

O valor residual final do período $\mathrm{T}$ ( anos ou horas) de vida útil é fornecida por:

$$
\mathrm{VRf}=\mathrm{VRI}-(\mathrm{T} \cdot \mathrm{TD})
$$

Onde:

$\mathrm{VRF}=$ Valor residual final.

$\mathrm{VRI}=$ Valor residual inicial.

$\mathrm{T}=$ Tempo em anos.

TD = Taxa de depreciação.

Para o cálculo do orçamento da colhedora em estudo, a depreciação econômica foi calculada pelos seguintes parâmetros:

Valor inicial $=$ US $\$ 267.000$.

Valor final $=10 \%$ do valor inicial $=$ US\$26.700.

Vida útil - 6 anos ou 18000 horas de trabalho, em função dos custos de manutenção da máquina. 
Valor Depreciação/ano = VI - VF / VU.

b) Juros

Os juros são definidos como sendo o produto da taxa de juros pela quantidade de dinheiro envolvido na aquisição da máquina, segundo Mialhe \& Carraro Neto(1993), foi calculado com a taxa de $12 \%$ a. a. sobre o valor residual da máquina em cada ano de uso. Esta taxa de juros foi fornecida pelo Banco do Brasil, sendo a praticada para financiamentos de máquinas agrícolas.

Juros $=.12 \%$ a. a.

O valor dos juros calculado por:

Juros máquina $=\mathrm{VR} \mathrm{m} \cdot 0,12$

onde:

$\mathrm{VR} \mathrm{m}=$ valor residual da máquina.

c) Seguro, Alojamento e Administração

O seguro, sendo uma taxa (prêmio), efetivado contra risco de incêndios e acidentes, segundo Mialhe (1974), foi estimado em uma taxa anual de 1,04\% sobre o valor residual da máquina a cada ano de uso, fornecida pelo Banco do Brasil, praticada para o financiamento de máquinas agrícolas.

Seguro máquina $=0,0104$. VR $\mathrm{m}$

Alojamento e administração foram calculados com um dispêndio na ordem de $50 \%$ do valor da taxa do seguro, referente ao primeiro ano de uso da máquina (Mialhe \& Carraro Neto, 1993).

$(\mathrm{AL}+\mathrm{Adm}$.$) / máquina =0,5 . \mathrm{SEm}$

Onde:

$\mathrm{AL}=$ Alojamento.

Adm. $=$ Administração.

$\mathrm{SEm}=$ Seguro da máquina . 
d) Consumo de combustível

O consumo de combustível foi estimado pelo fluxômetro nas determinações de campo em cada velocidade de trabalho, sendo posteriormente convertido em litros por tonelada de cana colhida para cada Capacidade Operacional analisada.

e) Óleo hidráulico

Foi estimado a partir dos levantamentos de consumo de óleo hidráulico em vàrias Usinas do Estado de São Paulo na safra (97/98). O consumo médio obtido foi de 0,017 litros para cada tonelada de cana colhida.

\section{f) Lubrificantes}

Os custos com consumo de lubrificantes foram determinados a partir das recomendações técnicas fornecidas pelo manual do fabricante da máquina.

g) Comboio de Manutenção, Abastecimento e Carro-pipa.

Os dispêndios referentes ao uso do comboio de manutenção, abastecimento e carro-pipa foram obtidos em Usinas que possuem sistemas de colheita e comboios. Os cálculos foram efetuados a partir dos gastos das Usinas em um ano, onde dividiu-se os valores dos custos pelo número de máquinas que faziam parte da frente de trabalho. Este custo foi dividido pelo número de horas anuais, encontrando-se o custo/hora do comboio de manutenção, abastecimento e carro-pipa da máquina em estudo.

h) Peças de Reposição e Filtros

Os custos associados às peças de reposição e filtros foram estimados pelos custos individuais de cada máquina, fornecidos por Usinas em diversas safras no Estado de São Paulo.

i) Mão-de-obra de mecânico 
Foi estimada por meio dos custos da quantidade de mecânico, em cada frente de colheita ao logo do ano, divididos pelo número de máquinas que faziam parte da respectiva frente, fornecido pelo departamento pessoal das Usinas pesquisadas, sendo composto por salários, encargos sociais e assistência social.

j) Mão-de-obra do operador da colhedora.

Foi determinada pelas informações fornecidas pelas Usinas, sendo o salário global composto do salário nominal, mais encargos sociais e assistência social.

Em seguida, foram elaboradas 16 planilhas com os fluxos de caixa formados pelos dispêndios de propriedade e operacionais. Somando-se estes dispêndios, estimouse o custo horário da colhedora.

Para a análise final, dividiram-se os custos horários encontrados pelos 16 valores de Capacidade Operacional, determinados através dos dados de Capacidade Efetiva bruta obtidos nos ensaios, multiplicados pelas Eficiências de Campo de 45, 55, 65, e $75 \%$. Obteve-se, em seguida, o custo (US\$) por tonelada de cana colhida. Os cenários foram determinados pelas relações entre os custos horários e as Capacidades Operacionais, calculadas pela seguinte equação:

US\$. $\mathrm{t}^{-1}=\left(\mathrm{US} \$ . \mathrm{h}^{-1}\right) /\left(\mathrm{t} . \mathrm{h}^{-1}\right)$

onde:

US $\$ \mathrm{t}^{-1}=$ Custo de colheita, US\$ por tonelada colhida.

US $\$ . h^{-1}=$ Custo horário, US\$ por hora.

t. $\mathrm{h}^{-1}=$ Capacidade Operacional, toneladas por hora.

A partir destes cenários estimaram-se as diversas possibilidades de custos para a colhedora. 


\section{RESULTADOS E DISCUSSÃO}

As tabelas com as análises estatísticas e econômicas encontram-se em anexo.

\subsection{Caracterização das condições de ensaio}

\subsubsection{Densidade média dos colmos, ponteiros, folhas verdes e palhas.}

Pelos resultados apresentados na Figura 13 e na Tabela 1, verifica-se que a massa vegetal total do canavial foi de 176,26 t.ha $^{-1}$, sendo que $82,40 \%$ constituiu-se de colmos de cana, ou seja, uma produtividade agrícola de 145,39 t.ha ${ }^{-1}$. O valor da produtividade média de colmos encontrado quando comparado com o valor da produção média colhida pela máquina nas 16 repetições observadas na Tabela 2, apresenta uma diferença em cerca de $44,5 \%$ maior. Este fato pode estar associado a coleta das amostras, uma vez que foi feita ao longo do talhão de 8,3 ha apresentando-se um desvio padrão de 38,85 , enquanto que, as 16 repetições utilizadas no ensaio só abrangeram uma área de 0,224 ha obtendo-se um desvio padrão de 16,0, ou provavelmente, em perdas que não se fez a mensuração, como por exemplo as perdas invisíveis, que segundo Moraes \& Neves (1997a), podem chegar até 5,4\%, e para De Beer (1980) até 6,0\%. No que se refere a uniformidade das 16 fileiras utilizadas no ensaio, realizou-se uma análise estatística da massa $(\mathrm{kg})$ do produto colhido nas 16 determinações, a mesma não apresentou diferenças significativas pelo teste $\mathrm{F}$ ao nível de $5 \%$ de probabilidade, conforme a Tabela 3, o que caracterizou aquela parte do talhão como uniforme. 


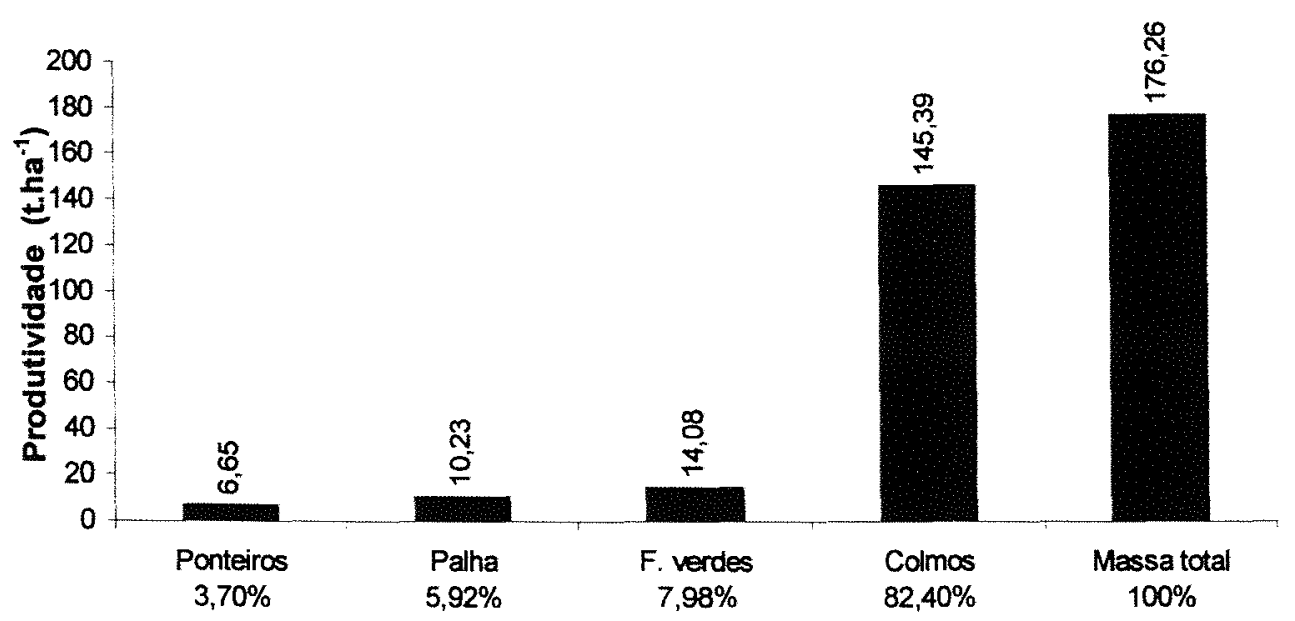

Figura 13. Resultados em peso e em percentual das frações constituintes do canavial.

\subsubsection{Porte do canavial}

Os resultados encontrados para o porte do canavial são apresentados na Figura 14 e na Tabela 4. Após a análise dos resultados verificou-se que 83,98\% encontravam-se em posição ereta. Segundo Ripoli (1996), a condição que apresentar maior percentagem definirá o porte do canavial. Neste caso, pode-se caracterizar o canavial em estudado como ereto.

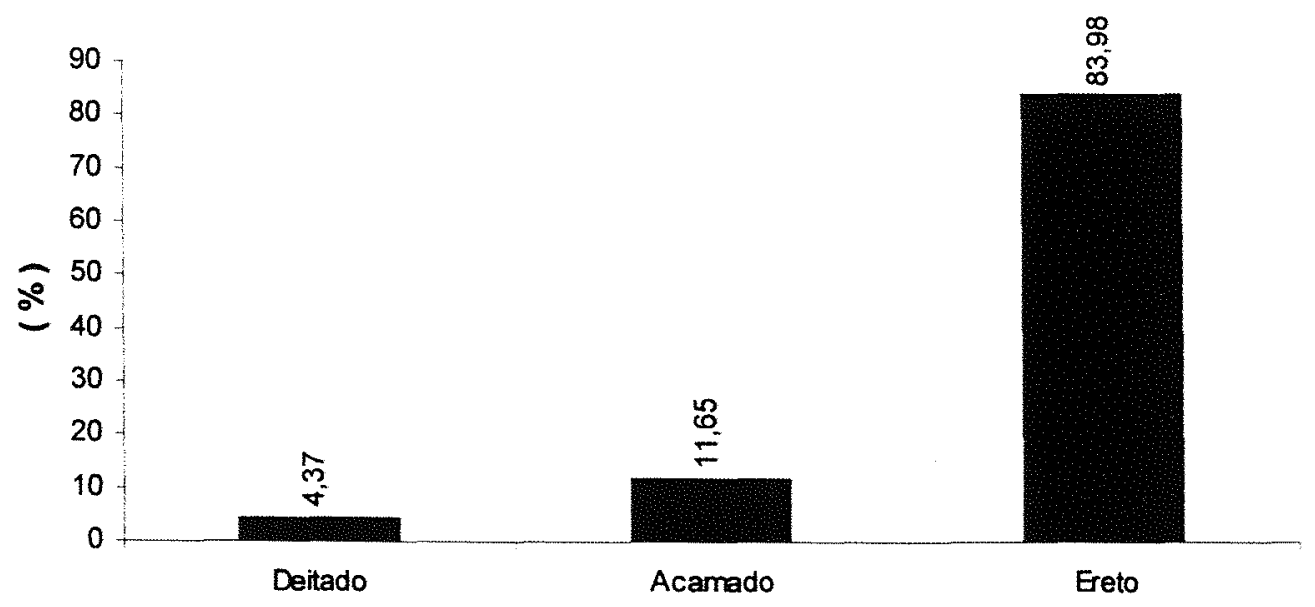

Figura 14. Resultado da caracterização do porte do canavial. 


\subsubsection{Comprimento médio dos colmos}

Os resultados encontrados para esta variável se encontram na Tabela 5 , onde verificou-se que a mesma apresentou um comprimento médio de 3,26 metros. De acordo com Ripoli (1996), o desvio padrão aceitável é 20 e o encontrado foi de 4,1 . Portanto o comprimento médio dos colmos encontrados estão dentro dos padrões de uniformidade necessários para a elaboração do ensaio.

\subsection{Teor de água do solo}

Os valores obtidos variaram de 9,12 a $21 \%$.

\subsubsection{Granulometria do solo}

Os resultados obtidos de granulometria do solo para areia total, silte e argila foram $31,4,11,8$ e $56,8 \%$, respectivamente.

\subsection{Grau de maturação da cultura}

Os valores analisados para Brix do caldo, Pol do caldo e fibra da cana foram 18 , 15,2 e $15,1 \%$, respectivamente.

\subsection{Desempenho operacional}

\subsubsection{Velocidade efetiva de deslocamento}

As velocidades efetivas de deslocamento diferiram significativamente ao nível de $5 \%$ de probabilidade, quando se aplicou o teste $F$, conforme mostrado na Tabela 6.

As médias das velocidades obtidas nos ensaios foram: $\mathrm{V} 1=1,34 \mathrm{~km} \cdot \mathrm{h}^{-1}, \mathrm{~V} 2=$ $2,66 \mathrm{~km} \cdot \mathrm{h}^{-1}, \mathrm{~V} 3=5,27 \mathrm{~km} \cdot \mathrm{h}^{-1}$ e V4 $=7,68 \mathrm{~km} \cdot \mathrm{h}^{-1}$. Pelo teste Tukey verificou-se as 
diferenças significativas entre as médias nos níveis de 1 e $5 \%$ de probabilidade como apresentado na Figura 15 e na Tabela 7.

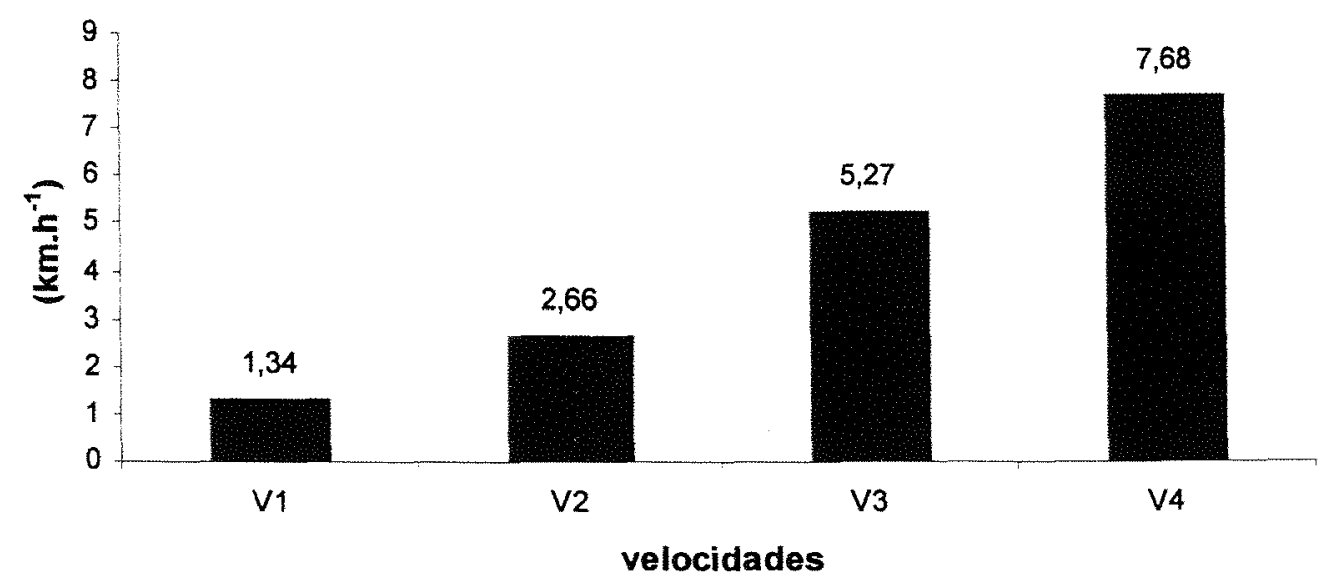

Figura 15. Médias das velocidades obtidas nos ensaios.

\subsubsection{Capacidade Efetiva Bruta - CEb}

A variável Capacidade Efetiva Bruta, foi analisada com finalidade de avaliar a quantidade de cana que a máquina colhe por hora efetiva de trabalho e auxiliar nos cálculos dos custos de colheita. A análise da variância revelou valor de F significativo ao nivel de $5 \%$ de probabilidade conforme a Tabela 8.

$\mathrm{Na}$ Tabela 9 são apresentados as variações entre as capacidades efetivas em suas respectivas velocidades, observa-se pela aplicação do teste Tukey, nos níveis de 5 e $1 \%$ de probabilidade, que as velocidades V3 e V4, não diferiram estatisticamente entre si, mas apresentaram diferenças estatísticas significativas com valores superiores quando comparados com as velocidades V1 e V2. Os maiores desempenhos obtidos para esta variável foram nas velocidades $\mathrm{V} 4$ e V3, com 110,18 e 87,67 t.h ${ }^{-1}$, respectivamente, como apresentado na Figura 16, porém inferiores aos encontrados nas modernas colhedoras da Austrália por Schembri \& Garson (1996) 120 a 180 t.h $^{-1}$. A capacidade efetiva bruta elevou-se com o aumento da velocidade de deslocamento, confirmando a proposição de Roseff (1989), sendo a Capacidade Efetiva Bruta função da velocidade. Nas velocidades V1 e V4 os valores foram próximos aos encontrados por Roseff (1989) 
17,4 e 91,6 t. $\mathrm{h}^{-1}$, respectivamente. Nas velocidades V2 e V3 os resultados foram semelhantes aos encontrados por Romero et al. (1993), 40 a 71 t.h $\mathrm{h}^{-1}$, em seis velocidades diferentes, variando de 3,6 a $5,8 \mathrm{~km} \cdot \mathrm{h}^{-1}$. A partir dos valores obtidos nota-se que as Capacidades Efetivas Brutas da colhedora avaliada apresentou melhora em relação aos modelos de 6 anos atrás. Os valores obtidos nas quatro velocidades estudadas são diferentes dos encontrados em canaviais sem queima prévia por: Soares et al (1994) 60,40 t.h $\mathrm{h}^{-1}$, Furlani Neto et al (1995) 59,11 t.h ${ }^{-1}$, Furlani Neto (1996) 57,78 t.h ${ }^{-1}$, Cenicaña (1997a) $70,60 \mathrm{t} \cdot \mathrm{h}^{-1}$, Cenicaña (1995) 45,21t.h. ${ }^{-1}$, Cenicaña (1997b) 73,00 t.h ${ }^{-1}$.

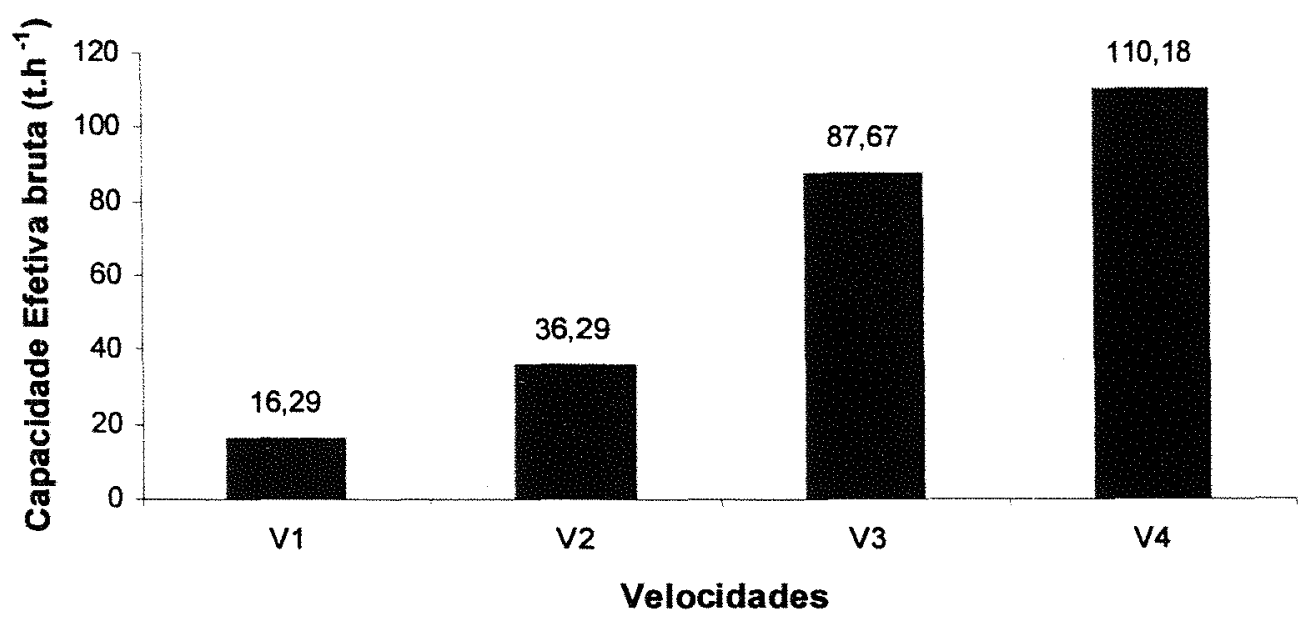

Figura 16. Capacidades Efetivas Brutas obtidas nas quatro velocidades estudadas.

\subsubsection{Capacidade Operacional - $\mathrm{COp}$}

A Capacidade Efetiva Bruta obtida em cada tratamento foi multiplicada por quatro diferentes Eficiências de Campo: 45, 55, 65 e 75\%. Estimando-se desta forma as 16 Capacidades Operacionais, como apresentado na Figura 17, e na Tabela 57. Foi verificado que, quando a velocidade aumenta, há um crescimento na capacidade operacional da colhedora. Pode-se inferir que velocidades muito baixas podem inviabilizar o uso da máquina em termos de desempenho econômico, como ocorre em algumas capacidades operacionais apresentadas no cenário proposto. Os resultados encontrados para capacidade operacional na velocidade V4 com uma Eficiência de 
Campo de $45 \%$, foi próximo à encontrada pelo Cenicaña (1997a) $47,60 t$ t. $^{-1}$, a $43 \%$ de eficiência de campo para a colhedora Austoft 7700 . Na velocidade V1 as capacidades operacionais encontradas foram inferiores às encontradas pelo Cenicaña (1996) $21,8 \mathrm{t} . \mathrm{h}^{-1}$ a $1,82 \mathrm{~km} \cdot \mathrm{h}^{-1}$, para a colhedora Austoft 7700 . Os valores obtidos nas velocidades V2 $75 \%$ e V3 $45 \%$ de eficiência de campo, foram próximos aos encontrados pelo Cenicaña (1995) 26,74, Boletim Técnico (1998) 33,8 e Strini Jr. (1999) 32,38 t.h ${ }^{-1}$, respectivamente. Apenas a Velocidade V2 nas eficiências de campo de 55 e $65 \%$ confirmaram os resultados do Relatório Técnico (1998) 20,80 a 23,62 t. $\mathrm{h}^{-1}$ para 48,42 a $55,70 \%$ de eficiência de campo.

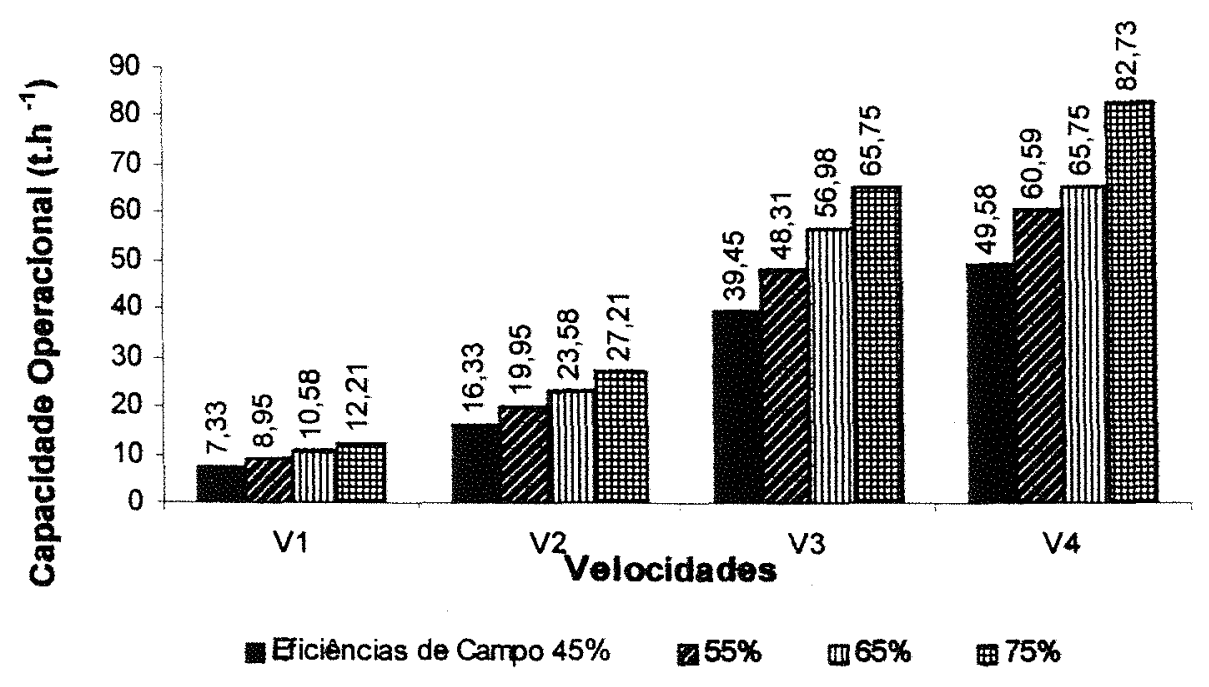

Figura 17. Resultados das Capacidades Operacionais nos quatro niveis de velocidades com quatro Eficiências de Campo.

\subsubsection{Eficácia de Manipulação - EM (\%)}

Para a variável Eficácia de Manipulação, aplicou-se o teste $\mathrm{F}$ e não apresentou diferenças significativas ao nível de $5 \%$ de probabilidade, como apresentado na tabela 10. A Figura 18 apresenta o comportamento da Eficácia de Manipulação em cada velocidade. As velocidades V3 e V4, apresentaram pequena diminuição em relação as velocidades V1 e V2. Comportamento semelhante foi verificado por Roseff (1998), 
quando afirmou que a Eficácia de Manipulação diminui á medida que aumenta a velocidade de deslocamento da máquina. Sendo necessário, uma melhor compatibilização entre o aumento da velocidade e essa variável para este tipo de máquina. Mesmo não apresentando diferenças significativas entre os tratamentos, notase que os valores encontrados nas determinações foram menores que os encontrados pelo Cenicaña (1997a) 96,35\%, para esta mesma colhedora sob condições de cana crua.

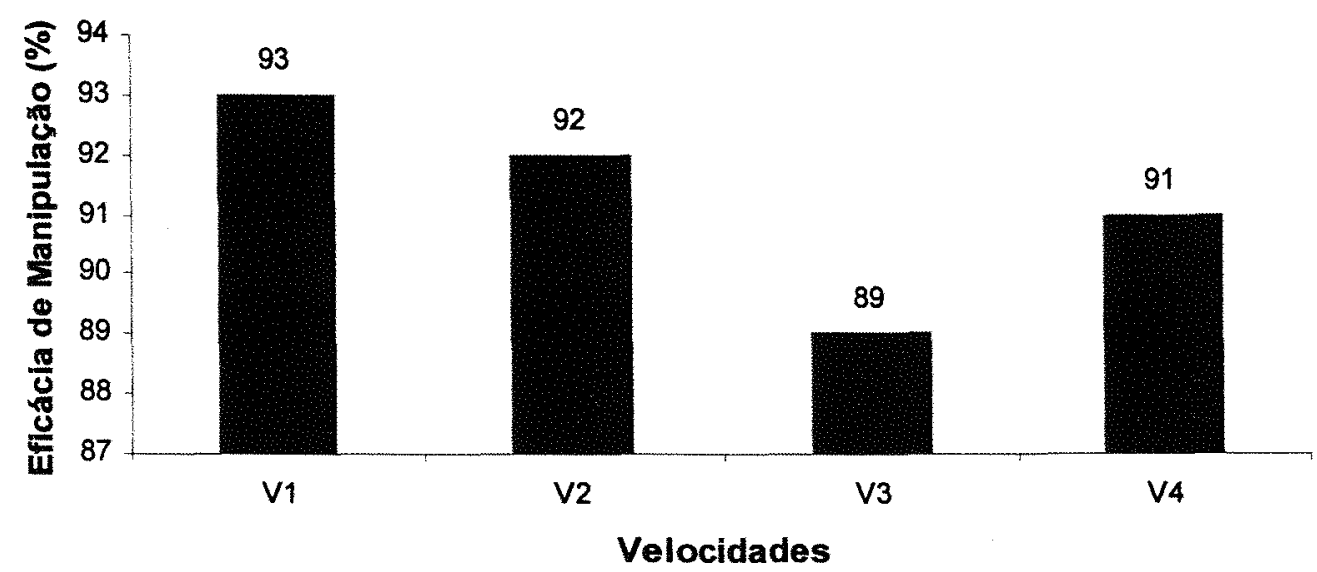

Figura 18. Eficácia de Manipulação para as quatro velocidades.

\subsubsection{Capacidade Efetiva Líquida - CEI}

A partir da análise estatística, pôde-se verificar valores de $\mathrm{F}$ significativos, ao nível de $5 \%$ de probabilidade para a interação velocidade e capacidade efetiva líquida, cujos dados encontram-se na Tabela 11 . Com a aplicação do teste Tukey a 1 e $5 \%$ na Tabela 12, nota-se que as velocidades V4 e V3 apresentaram diferenças significativas maiores que as velocidades V1 e V2, sendo que a velocidade V4 foi superior a todas as velocidades. Já as velocidades V2 e V1 não apresentaram diferenças significativas entre si. Para esta variável verificou-se na Figura 19, um aumento na capacidade efetiva à medida que se aumentou a velocidade de deslocamento da colhedora, este comportamento foi semelhante ao encontrado por Roseff (1989). Na velocidade V3, os valores obtidos foram próximos aos encontrados por Mialhe \& Carraro Neto (1993) 
$73,47 \mathrm{t} . \mathrm{h}^{-1}$ para a velocidade de $3,0 \mathrm{~km} . \mathrm{h}^{-1}$ em colhedora CC 2000 . Nas velocidades V4 e V3, os valores foram maiores que os encontrados pelo Cenicaña (1977a) 68,02 t.h $^{-1}$ na colhedora Austoft 7700 .

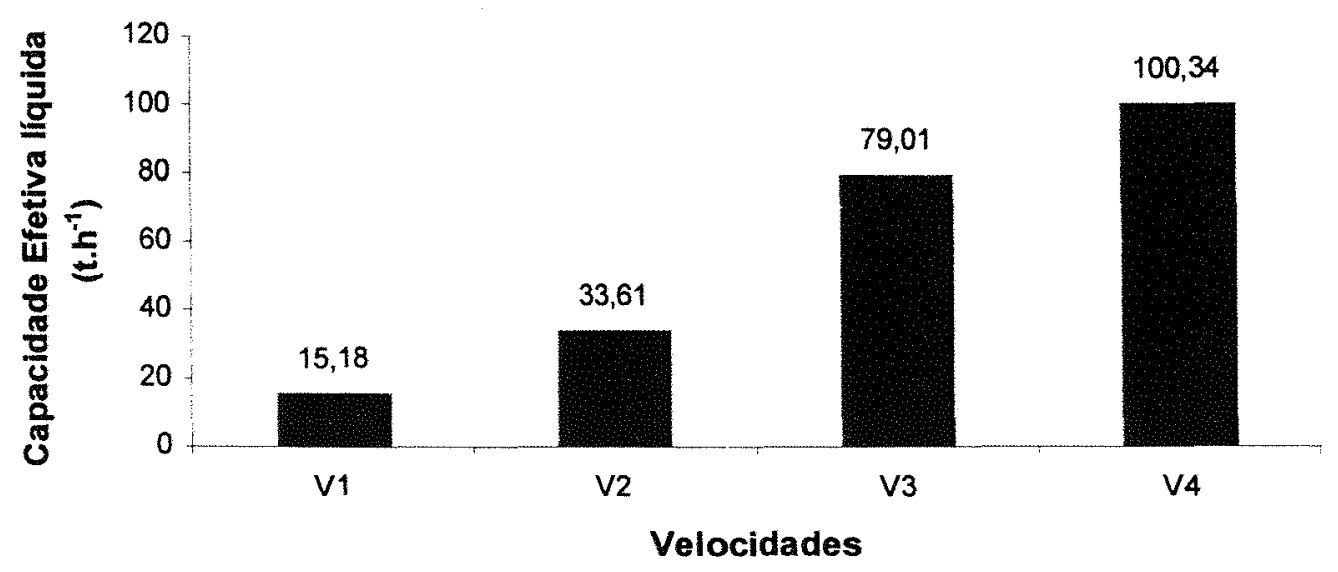

Figura 19. Capacidades Efetivas Líquidas determinadas.

\subsubsection{Consumo de Combustível}

Os resultados das análises do consumo de combustível em $\left(1 . \mathrm{t}^{-1}\right)$ e em $\left(1 . \mathrm{h}^{-1}\right)$, foram significativas com a aplicação do teste $\mathrm{F}$ ao nível de $5 \%$ de probabilidade, segundo os resultados apresentados nas Tabelas 13 e 14.

Na Tabela 15 são verificadas as diferenças entre as médias pelo teste Tukey, nos níveis de 1 e $5 \%$, para o consumo de combustível em $\left(1 . t^{-1}\right)$ colhida. A velocidade V1 apresentou diferença significativa quando comparada às demais velocidades, obtendo-se o maior consumo. A velocidade V4 apresentou menor consumo que as velocidades V3 e V2, mesmo não demonstrando diferenças significativas. Na Figura 20, observa-se em relação a velocidade V1 que o consumo foi alto, chegando a alcançar cinco vezes maior que nas velocidades V4 e V3. Pode-se inferir que a velocidade ótima de operação em termos econômicos para esta colhedora estão entre as velocidades de deslocamento V3 e V4 em decorrência do menor consumo de combustível. Sendo necessário assim, criar 
condições nos canaviais para que as máquinas operem com velocidades maiores, podendo gerar economia de combustível. Resultados semelhantes a velocidade V2 foram encontrados pela Cenicaña (1995) $1,321 . \mathrm{t}^{-1}$ para a colhedora Austoft 7700, Scandaliares et al. (1997) 0,9 a 1,6 1.t $\mathrm{t}^{-1}$, Lima (1998) 0,81 a 1,56 1.t $\mathrm{t}^{-1}$, Strini Jr. (1999), 1,25 1.t $\mathrm{t}^{-1}$ para colhedora Brastoft 7700. Já as velocidades V3 e V4 obtiveram consumos menores que os autores citados anteriormente. O valor encontrado na velocidade V3, foi próximo ao encontrado por Cury (1999) $0,791 . t^{-1}$ para colhedora Brastoft em canaviais sem queima prévia.

Analisando-se o consumo de combustível, em $1 . \mathrm{h}^{-1}$ (Tabela 16), ao nível de 5\% pelo teste Tukey, verificou-se que a velocidade V4 apresentou diferença significativa superior as demais velocidades, apresentando maior consumo. As velocidades V1 e V2 não apresentaram diferenças significativas entre si, mas obtiveram os menores consumos. Na Figura 21 verifica-se que, o consumo de combustível na velocidade V4 foi maior que na velocidade V1 em torno de 30\%. Como o consumo de combustível é dada pelos órgãos internos da colhedora que trabalharam em rotação constante para todas as velocidades, o menor consumo foi causado pelo menor esforço provocado pela menor fluxo de cana nas mais baixas velocidades de deslocamento. Os valores encontrados para esta variável nos quatro níveis de velocidades no ensaio foram maiores que os encontrados pela Cenicaña (1995) $35,21 . \mathrm{h}^{-1}$, Strini Jr. (1999) 38,38 $1 . \mathrm{h}^{-1}$ para colhedoras Autoft 7700, Boletim Técnico (1998) $35,01 . \mathrm{h}^{-1}$ para a colhedora Brastoft e Relatório Técnico (1998) 25,48 a 28,17 1. $\mathrm{h}^{-1}$. 


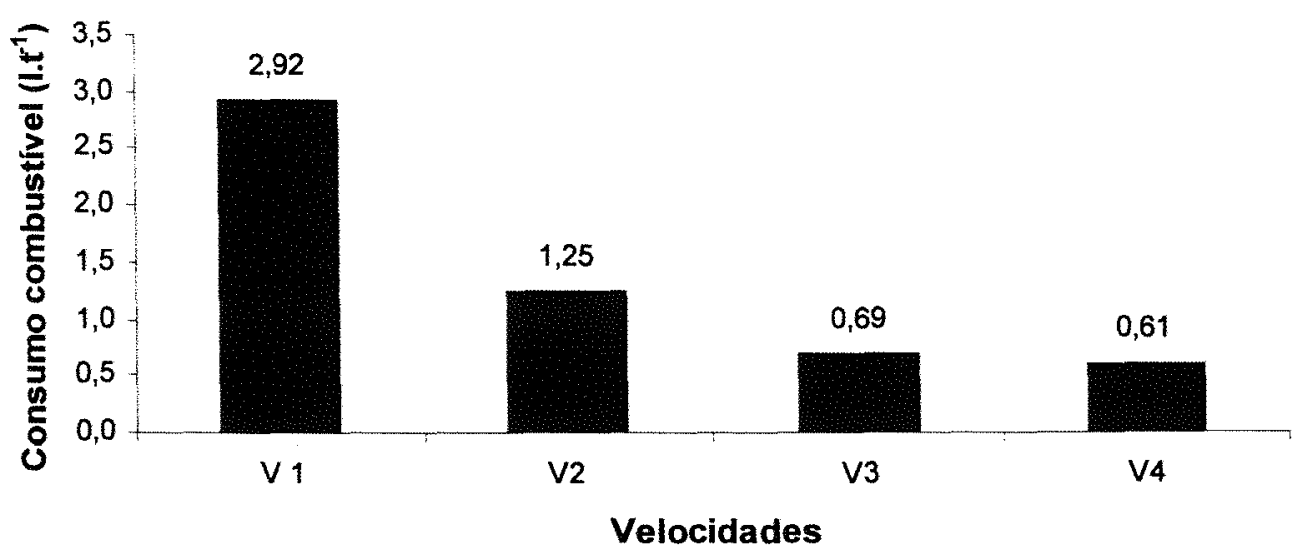

Figura 20. Consumo de combustível por matéria-prima colhida $\left(1 . t^{-1}\right)$, determinada para os quatro níveis de velocidades estudadas.

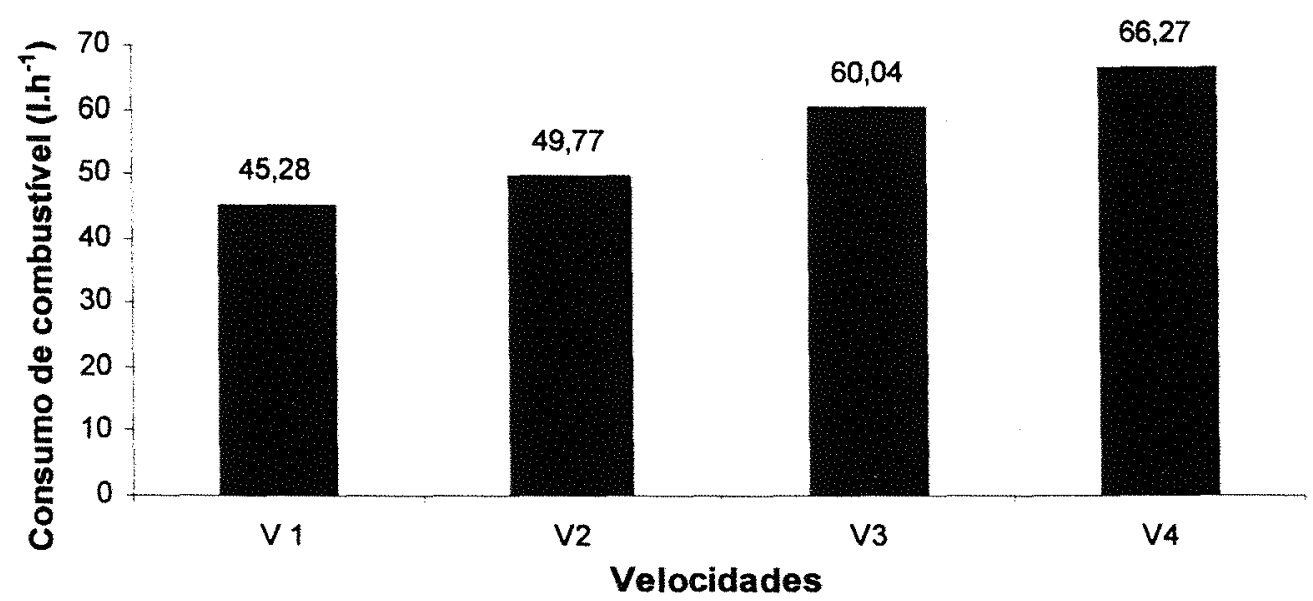

Figura 21. Consumo de combustivel por hora de trabalho $\left(1 . h^{-1}\right)$, determinada para os quatro níveis de velocidades estudadas.

Os resultados médios de desempenho da colhedora nas quatro velocidades estudadas, estão resumidas na Tabela 17. 
Tabela 17. Resumo dos resultados médios de desempenho da colhedora.

\begin{tabular}{cccccc}
\hline Veloc. & $\begin{array}{c}\text { CEb } \\
\left(\text { t. }^{-1}\right)\end{array}$ & $\begin{array}{c}\text { EM } \\
(\%)\end{array}$ & $\begin{array}{c}\text { CEl } \\
\left(\text { t. }^{-1}\right)\end{array}$ & $\begin{array}{c}\text { C. comb } \\
\left(1 . \mathrm{t}^{-1}\right)\end{array}$ & $\begin{array}{c}\text { C comb } \\
\left(1 . h^{-1}\right)\end{array}$ \\
\hline V1 & 16,29 & 0,93 & 15,18 & 2,92 & 45,28 \\
V2 & 36,29 & 0,92 & 33,61 & 1,25 & 49,77 \\
V3 & 87,67 & 0,89 & 79,01 & 0,69 & 60,04 \\
V4 & 110,18 & 0,91 & 100,34 & 0,61 & 66,27
\end{tabular}

$\mathrm{CEb}=$ Capacidade Efetiva Bruta; $\mathrm{EM}=$ Eficácia de Manipulação; $\mathrm{CEl}=$ Capacidade Efetiva Líquida; C. Comb = Consumo de combustível;

\subsection{Perdas de matéria-prima no campo}

\subsubsection{Na forma de colmos e frações de colmos}

Com aplicação do teste $\mathrm{F}$ ao nível $5 \%$ de significância, não houve diferença significativa para esta variável nas quatros velocidades, conforme o resumo da análise de variância, apresentado na Tabela 18.

$\mathrm{Na}$ Figura 22 verifica-se que a velocidade V3, embora tenha apresentado um valor muito baixo não demonstrou diferença significativa, isso se deve ao fato desta variável apresentar coeficiente de variação de 50,95\%. Observou-se que mesmo não ocorrendo diferença significativa o valor médio na velocidade V3, apresentou a menor perda. As velocidades V1, V2 e V4 obtiveram perdas de colmos e frações, semelhantes as encontradas por Lima (1994) 2,40\% em canaviais sem queima prévia para colhedora Engeagro 8000 e maiores que os encontrados por Furlani Neto (1995) 0,15 e 1,11\% em duas variedades para canaviais sem queima prévia. Com base nos resultados nota-se que a máquina avaliada apresenta pouca inovação em relação aos modelos mais antigos, mesmo apresentando valores menores que os citados por Fernandes \& Irvine (1986), 2,0 a $10 \%$. 


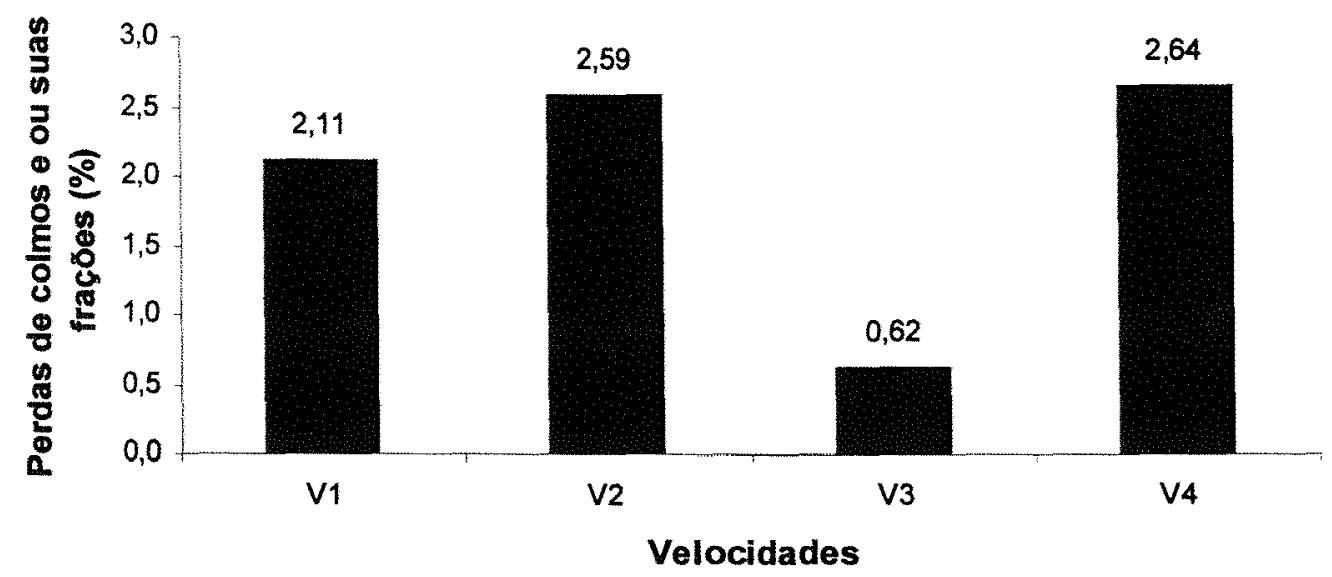

Figura 22 Resultados da Perdas de colmos e ou suas frações, nas velocidades estudadas.

\subsubsection{Na forma de rebolos}

$\mathrm{Na}$ tabela 19, verifica-se que houve diferenças significativas, ao nível de $5 \%$ de probabilidade, para a variável perdas na forma de rebolos. Ao se comparar as médias, (teste Tukey Tabela 20) e na Figura 23, observou-se que apenas a velocidade V3, apresentou diferença significativa superior nos níveis de 1 e $5 \%$ de significância, constituindo-se na velocidade que obteve maior perda na forma de rebolos. Os valores encontrados nas velocidades V1, V2 e V4 são bastantes satisfatórios em relação aos encontrados por Furlani Neto (1995) 0,79 e 1,69\% para duas variedades estudadas em canaviais sem queima prévia, Cenicaña (1997a) 1,4\% para colhedora Austoft e menores que os encontrados por Lima (1994) 1,49\%. 


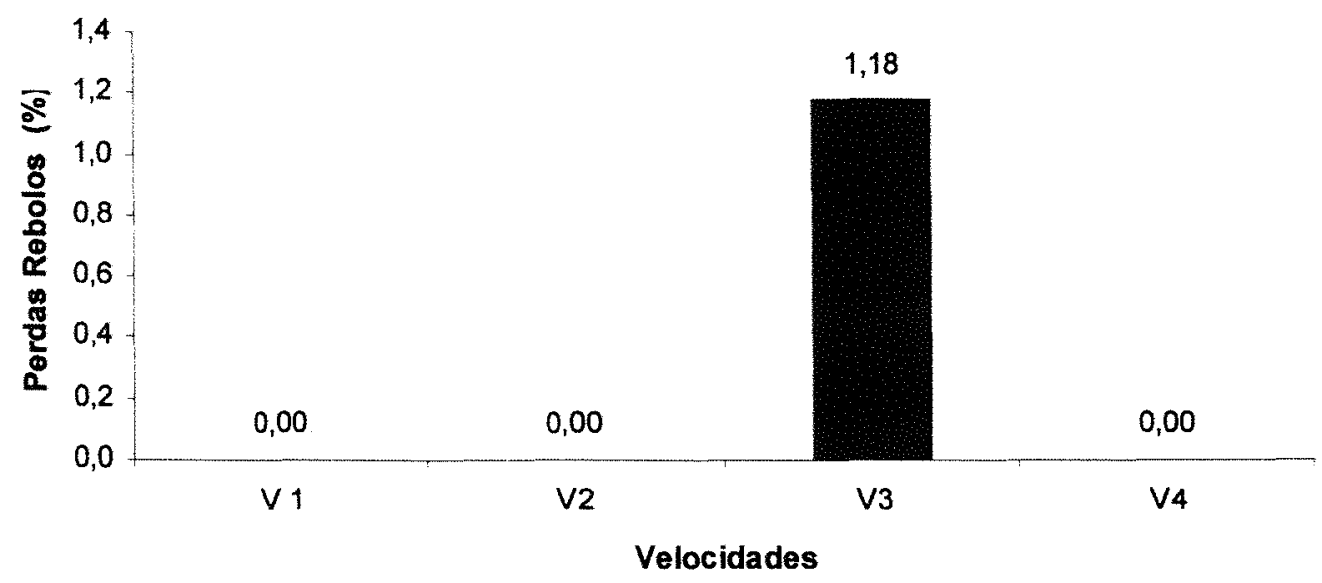

Figura 23. Resultados das perdas referentes aos rebolos.

\subsubsection{Na forma de frações de rebolos}

As frações de rebolos encontradas no campo após a colheita, não demonstraram diferenças significativas quando se aplicou o teste $\mathrm{F}$ ao nível de $5 \%$ de probabilidade, conforme a Tabela 21. Pode-se inferir que a máquina nesta variável, apresentou harmonia perfeita entre o mecanismo de corte basal com o aumento da velocidade de deslocamento (Figura 24), mesmo assim, os valores apresentados na Tabela 24, são considerados altos, em relação aos encontrados para modelos mais antigos por Furlani Neto (1995) 0,35 a 0,29\% nas variedades SP 71-1406 e SP 71-6163, em canaviais sem queima prévia. 


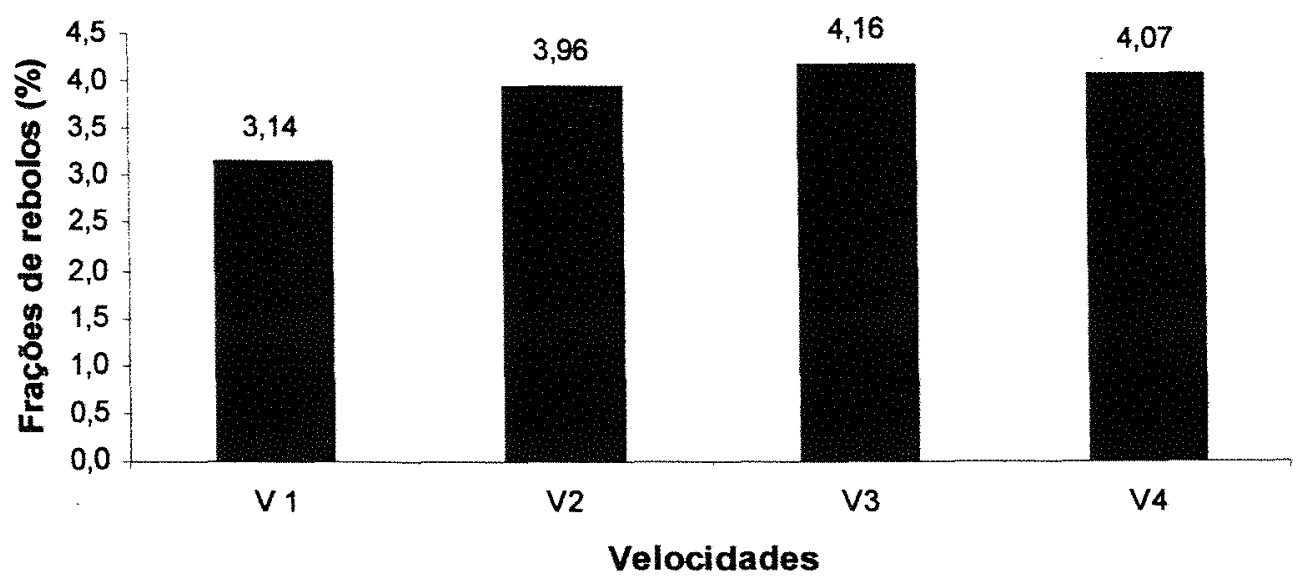

Figura 24. Resultados das frações de rebolos encontradas no campo após a colheita.

\subsubsection{Na forma de frações de colmos na soqueira.}

Houve diferença significativa quando se aplicou o teste $\mathrm{F}$ ao nível de $5 \%$ de probalidade, para a variável perda de frações de colmos na soqueira (Tabela 22). Ao aplicar o teste Tukey (Tabela 23), verifica-se que a velocidade V3 demonstrou diferença significativa superior as demais velocidades, este fato deve estar associado ao cortador de base que provavelmente operou nesta velocidade em uma altura maior em relação ao solo, que nas demais velocidades avaliadas. As velocidades V1 e V2 ao nível de 5\% de probabilidade não apresentaram diferenças significativas entre si constituindo-se nas menores perdas. A velocidade V4, não apresentou diferença significativa, quando comparada com a velocidade V3, sendo que ambas apresentaram as maiores perdas. Quando se aplicou o teste a $1 \%$ de probabilidade, houve uma diferença significativa entre as velocidades V3 e V2, enquanto que as velocidades V1 e V4, apresentaram comportamentos iguais. Na Figura 25 são apresentados os valores médios para os tratamentos, verifica-se que a elevação da velocidade de deslocamento provocou aumento das perdas na forma de frações de colmos na soqueira, demonstrando sincronismo imperfeito entre a velocidade de deslocamento e o mecanismo de corte da 
colhedora. Os valores para as velocidades V1 e V2 são próximos aos encontrados por Lima (1984) 0,82\% em colhedora Engeagro 8000 e Furlani Neto (1995) 0,70 e 0,50\%.

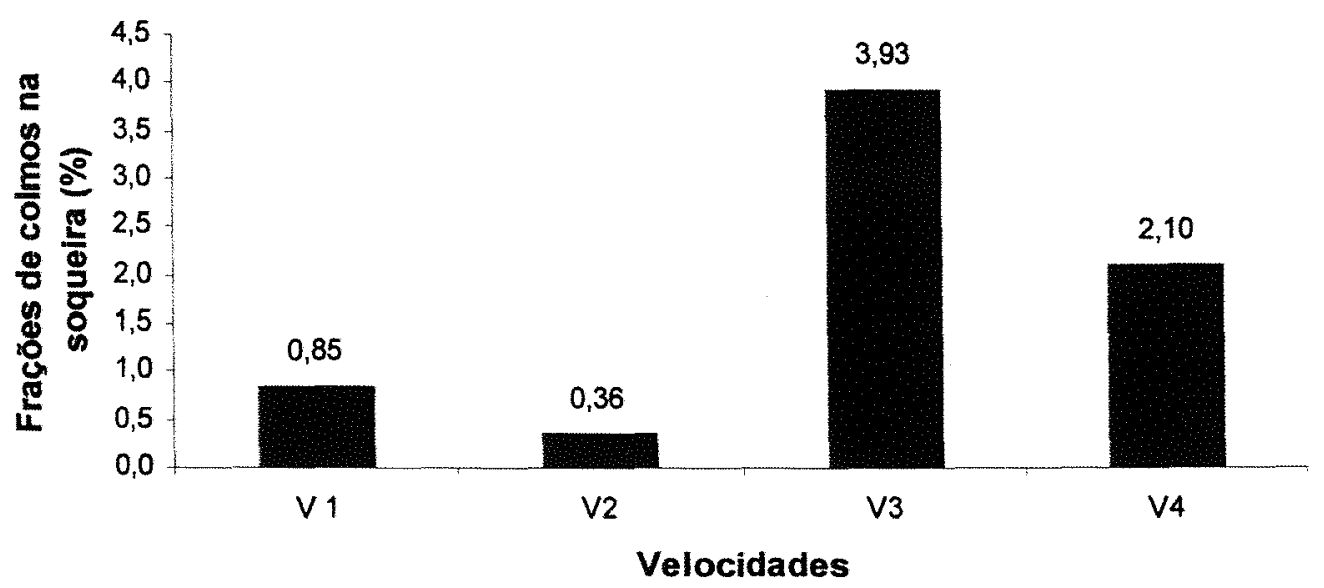

Figura 25. Perdas na forma de frações de colmos na soqueira.

\subsubsection{Raízes arrancadas}

Pelo resumo da análise da variância (Tabela 24), observa-se que houve diferença significativa ao nível de $5 \%$ de probabilidade entre as velocidades e a quantidade de raízes arrancadas. Ao aplicar o teste Tukey (Tabela 25), ao nível de $1 \%$ de probabilidade, verificou-se que não houve diferença significativa entre as velocidades. Ao nível de $5 \%$ de probabilidade, nota-se que a velocidade V4 apresentou diferença significativa somente em relação a velocidade V1. As velocidades V3 e V2 obtiveram o mesmo comportamento em termos estatísticos, porém diferentes em termos numéricos, ou sejam 0,08 e 0,58 t.ha ${ }^{-1}$ (Figura 26), na velocidade V3 a quantidade de raízes arrancadas foi menor, este comportamento se deve ao fato do cortador de base trabalhar em posição mais alta em relação as outras velocidades. A velocidade V4 apresentou uma quantidade superior de raízes arrancadas em relação as outras velocidades, chegando a 0,90 t.ha $^{-1}$, demonstrando que à medida que se eleva a velocidade de deslocamento da máquina, há um aumento na quantidade de raízes arrancadas, que conforme Roseff (1989), a elevação da velocidade de deslocamento aumenta a força com que o 
mecanismo de corte basal atua sobre a base da cana, provocando maior arrancamento das raizes.

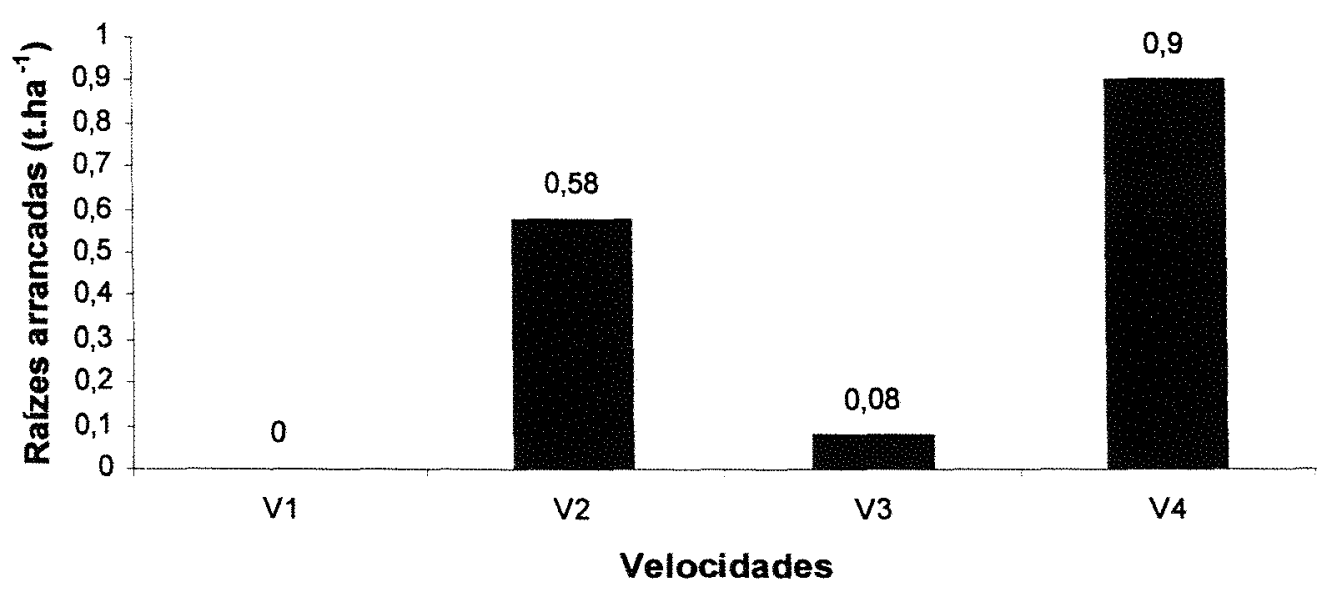

Figura 26. Quantidade de raízes arrancadas pela máquina nas quatro velocidades estudadas.

\subsubsection{Perdas Totais de matéria-prima}

Observando a Tabela 26, verifica-se que não houve diferença significativa, ao nível de $5 \%$ de probabilidade mediante aplicação do teste $\mathrm{F}$. Assim, as perdas totais de matéria-prima não foram influenciadas pelo aumento da velocidade de deslocamento da colhedora, mesmo com as variáveis perdas na forma de rebolos e na forma de frações de colmos apresentando diferenças significativas. Na Figura 27 verifica-se que as perdas totais variaram em torno de 6,1 a $9,89 \%$, por este comportamento nota-se que a colhedora analisada deixa uma quantidade considerável de cana no campo, uma vez que valores menores foram obtidos por Lima (1994) 4,71\%, Moraes \& Neves (1997b) 1,4 a $5,6 \%$ e pelo Cenicaña (1997a) 3,65\% em colhedora Austoft 7700. Mesmo assim, os valores obtidos podem ser considerados baixos quando comparados aos determinados em canaviais sem queima prévia por Ridge \& Dick (1987) 14,9 a 16,4\%, Izumi \& Ueno (1983) 10 a 15\%, Dick \& Greves-James (1992) 5,5 a 19,9\%, Hurney et al. (1994) 3,0 a $7,0 \%$, Scandaliares et al (1997) 6,12 a 14,8\%, Strini Jr. (1999) 6,98\%. 


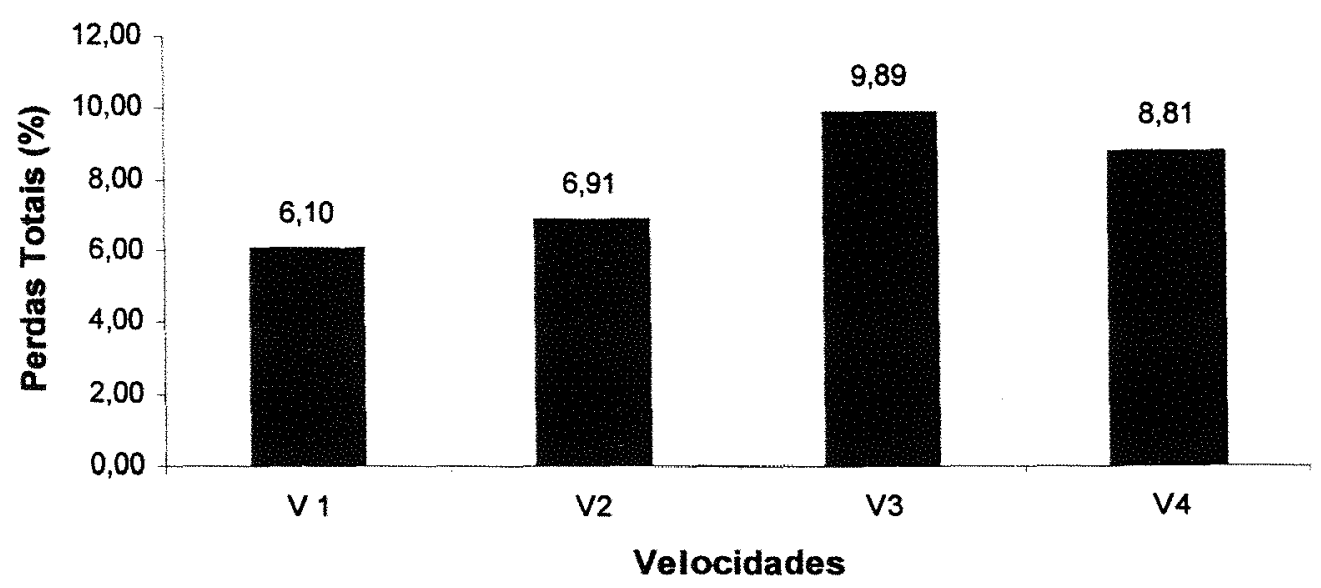

Figura 27. Resultados das Perdas Totais de matéria prima para as velocidades estudadas.

Os resultados médios das perdas de matéria-prima no campo da colhedora nas quatro velocidades estudadas estão resumidos na Tabela 27.

Tabela 27. Resumo dos valores médios das perdas de matéria-prima no campo da colhedora e total de raízes arrancadas.

\begin{tabular}{ccccccc}
\hline $\begin{array}{c}\text { Niveis de } \\
\text { velocidade }\end{array}$ & $\begin{array}{c}\text { Colmos e } \\
\text { frações(\%) }\end{array}$ & $\begin{array}{c}\text { Rebolos } \\
(\%)\end{array}$ & $\begin{array}{c}\text { Frações de } \\
\text { rebolos(\%) }\end{array}$ & $\begin{array}{c}\text { Colmos nas } \\
\text { soqueiras(\%) }\end{array}$ & $\begin{array}{c}\text { Perdas } \\
\text { totais (\%) }\end{array}$ & $\begin{array}{c}\text { Raízes } \\
\left.\text { (t.há }^{-1}\right)\end{array}$ \\
\hline V1 & 2,11 & 0,00 & 3,14 & 0,85 & 6,10 & 0,00 \\
V2 & 2,59 & 0,00 & 3,96 & 0,36 & 6,91 & 0,58 \\
V3 & 0,62 & 1,18 & 4,16 & 3,93 & 9,89 & 0,08 \\
V4 & 2,64 & 0,00 & 4,07 & 2,10 & 8,81 & 0,90 \\
\hline
\end{tabular}

\subsection{Análise da matéria estranha no material colhido.}

\subsection{1 Índice de Ponteiros - IP (\%)}

Não houve diferença significativa com a aplicação do teste $\mathrm{F}$ ao nível de $5 \%$ de probabilidade (Tabela 28), para o Índice de Ponteiros aderidos à matéria-prima. Verifica-se pela Figura 28, que a quantidade de ponteiros variou entre 4,38 a 7,06\%. 
Valores considerados altos, pois segundo Roseff (1989), podem diminuir a pureza do caldo. Estes resultados elevados podem estar relacionados, provavelmente, ao fato da máquina ter operado no ensaio com o despontador desligado. Os resultados obtidos na velocidade V1 confirmam os encontrados por Herreira e Linares (1986) 7,9\%, em canaviais sem queima prévia.

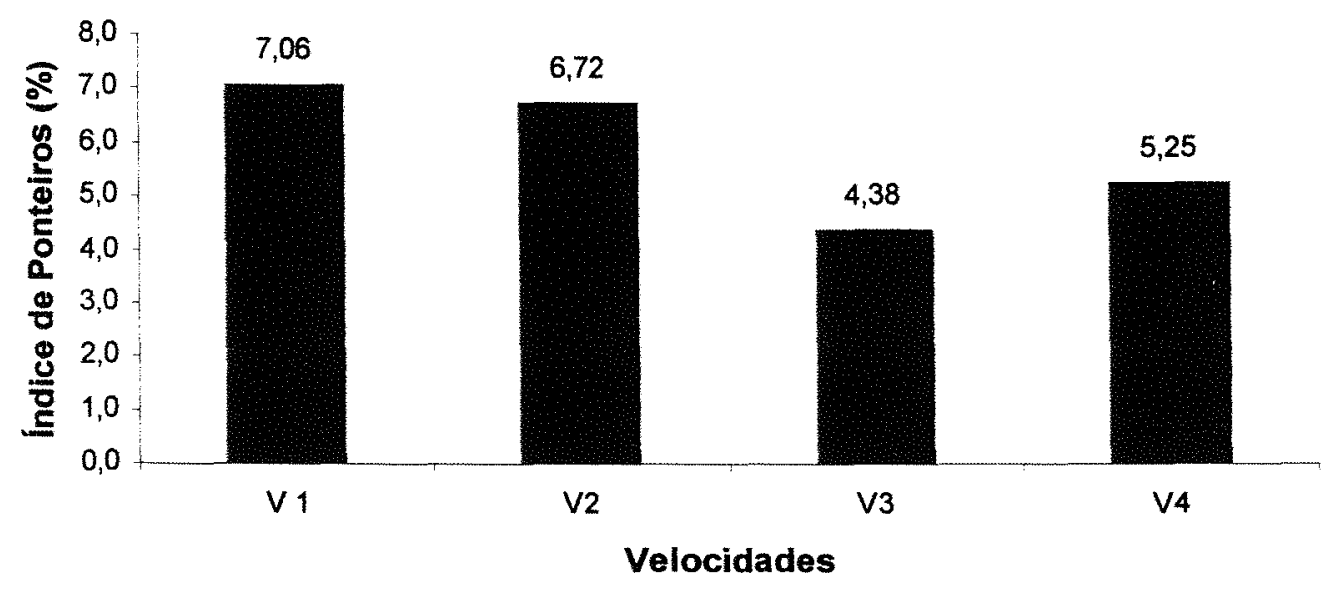

Figura 28. Resultados da massa de ponteiros contidos na matéria-prima colhida.

\subsection{2 Índice de Folhas - IF (\%)}

A Tabela 29 apresenta a análise da variância com valores significativos com aplicação do teste $\mathrm{F}$, ao nível de $5 \%$ de probabilidade quando considerou-se a variável Indice Folhas.

Com a aplicação do teste Tukey (Tabela 30), ao nível de 5\% de probabilidade, verificou-se que na velocidade V1 ocorreu diferença significativa inferior quando se comparou com as velocidades V3, V4 e V2. Ao nível de 1\% de probabilidade, a velocidade V3 apresentou diferença significativa superior, somente em relação a velocidade V1. A partir das análises nota-se que à medida que ocorre aumento da velocidade de deslocamento a eficiência de limpeza da máquina diminui, como se verifica na Figura 29. Estes resultados não foram satisfatórios, pois com o acréscimo de $1 \%$ no Índice de folhas há um aumento de 0,36 no teor de fibra (Fors \& Arias, 1977). 


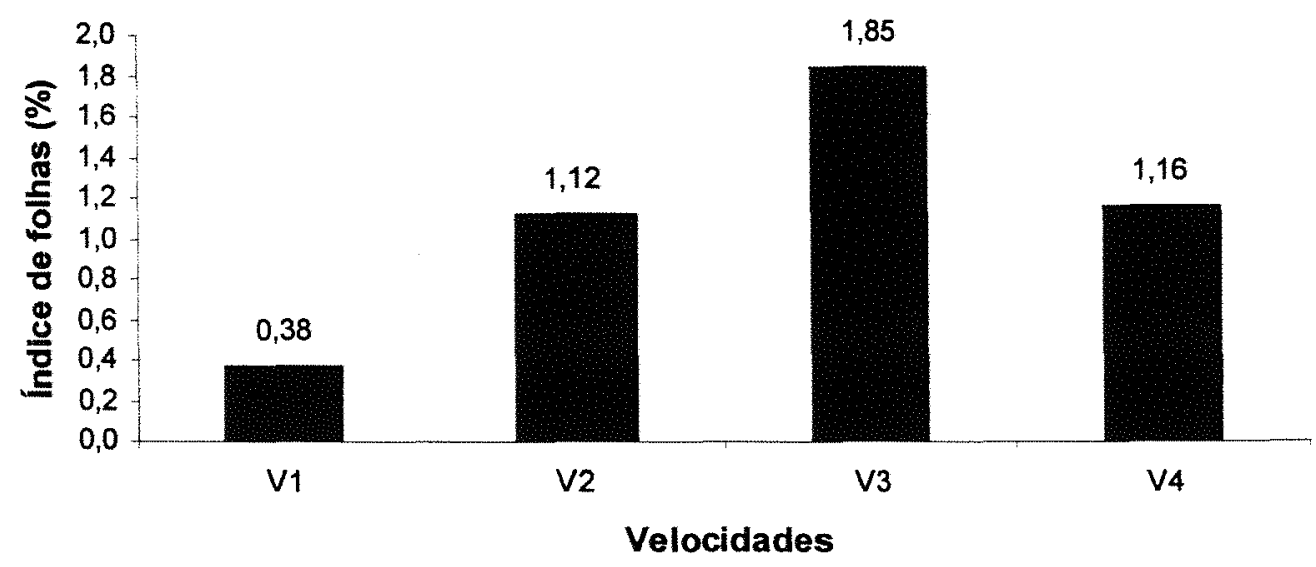

Figura 29. Percentagem de folhas verdes encontradas na matéria-prima colhida.

\subsection{3 Índice de Palhas - IP (\%)}

Para a quantidade de palhas encontradas na matéria-prima, a análise estatística não apresentou diferenças significativas com a aplicação do teste $\mathrm{F}$, ao nível de $5 \%$ de probabilidade, conforme observado na Tabela 31 . Na figura 30 , pode-se observar que a velocidade V4, apresenta valor médio para o Índice de Palha superior ao encontrado nas demais velocidades, demonstrando que a eficiência de limpeza diminui a medida que a velocidade de deslocamento aumenta. Os resultados encontrados são menores que os determinados por Herreira \& Linares (1986) 2,0\% em canaviais sem queima prévia. 


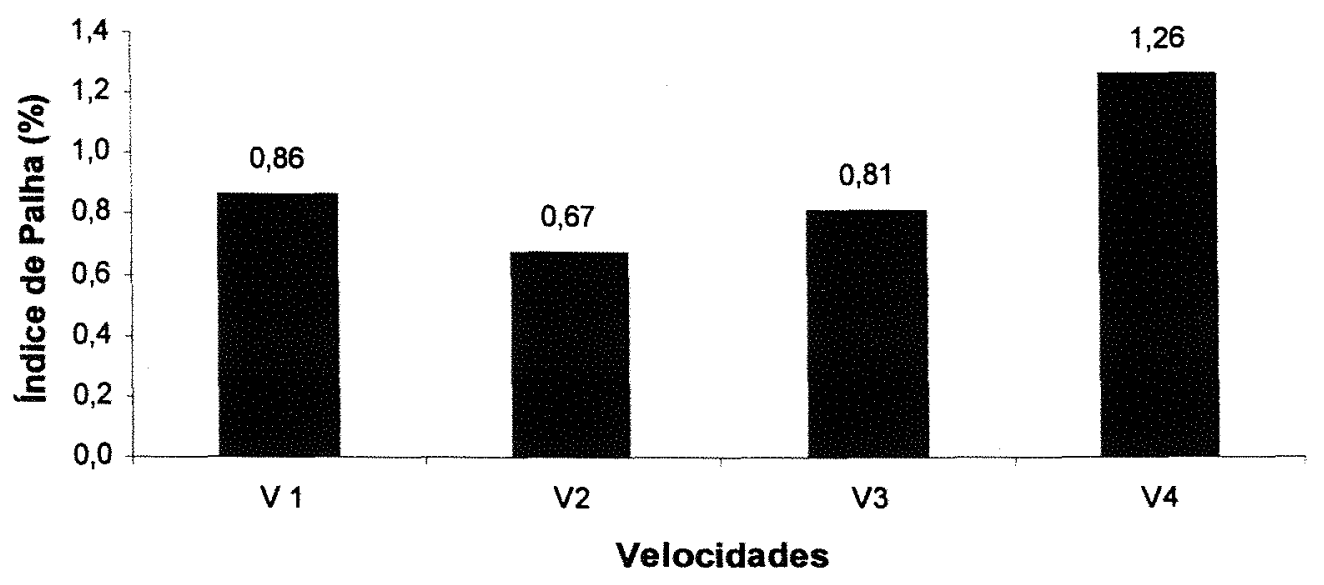

Figura 30. Quantidade de palhas encontrada na matéria prima

\subsection{4 Índice de Raízes - (IR)}

O Índice de raízes encontrado na matéria-prima, foi significativo com a aplicação do teste $\mathrm{F}$ ao nível de $5 \%$ de probabilidade (Tabela 32 ). Com a aplicação do teste Tukey, ao nível de $5 \%$ de probabilidade (Tabela 33) e (Figura 33), verificou-se que a velocidade V2, apresentou diferença significativa superior em relação as velocidades V1, V3 e V4. As velocidades V1, V3 e V4 não diferiram estatisticamente entre si, sendo seus valores $0,12,0,15$ e $0,73 \%$ respectivamente. Na velocidade V2, o Índice de raiz foi de $2,37 \%$, sendo maior que as demais velocidades, este fato pode ter ocorrido, provavelmente, devido ao operador trabalhar nesta velocidade, com mecanismo de corte basal muito baixo, para Fors \& Arias (1977) 1\% de aumento no Índice de Raizes pode provocar decrescimo de 0,39 na pureza do caldo. Segundo Roseff (1989), Índice de Raízes elevado pode aumentar o teor de fibra da cana. Ao nível de $1 \%$ de probabilidade, não houve diferença significativa entre as velocidades. 


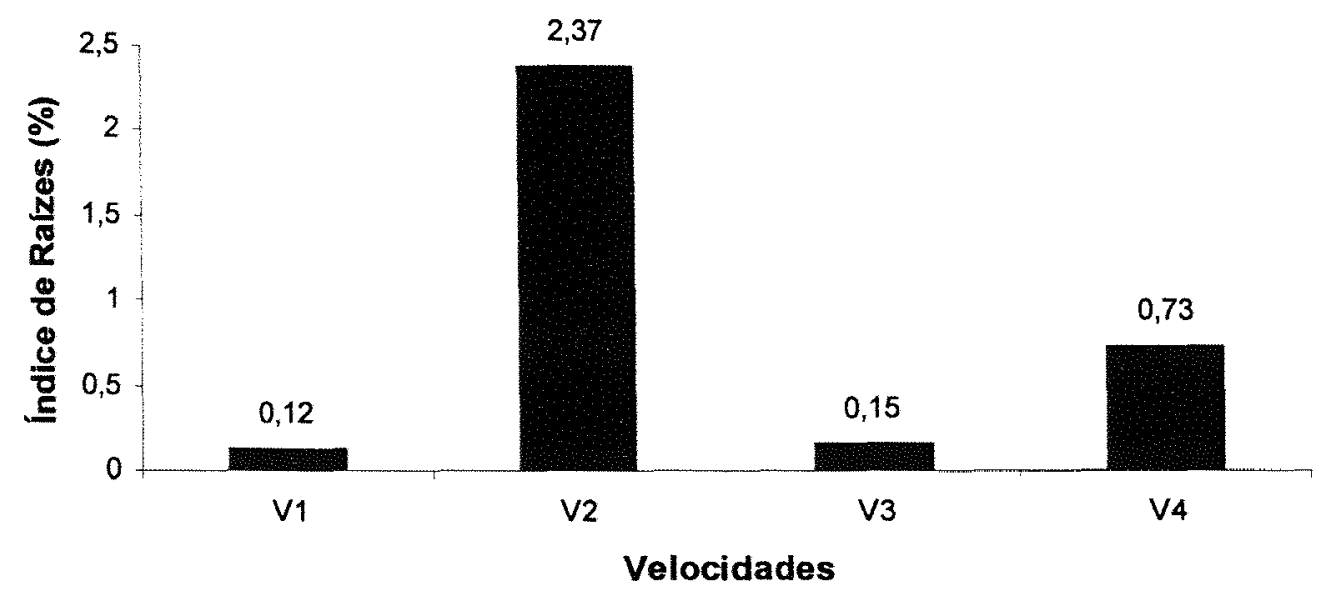

Figura 31. Percentuais de raízes encontradas na matéria-prima colhida.

\subsection{5 Índice de Matéria Estranha Vegetal - IV (\%)}

Para esta variável a análise estatística com a aplicação do teste $F$, não apresentou diferenças significativas ao nível de $5 \%$ de probabilidade (Tabela 34). A velocidade V2 apresentou valor médio maior, demonstrando comportamento inferior as outras velocidades como verificado na Figura 32. Mesmo não ocorrendo diferença estatística significativa entre as velocidades, notou-se que a quantidade de matéria estranha vegetal encontrada na matéria-prima, obteve valores numéricos baixos em termos de cana sem queima prévia, pois os valores encontrados são menores que os determinados por Fernandes \& Irvine (1986) 6,0 a 17,0\%, Furlani Neto (1995) 5,59 a 10,70\%, Moraes \& Neves (1997b) 8,5 a 11,2\% e menores foram encontrados por John (1992) 1,0 a 2,0\%, Lima (1994) 5,5\%, em canaviais sem queima prévia. 


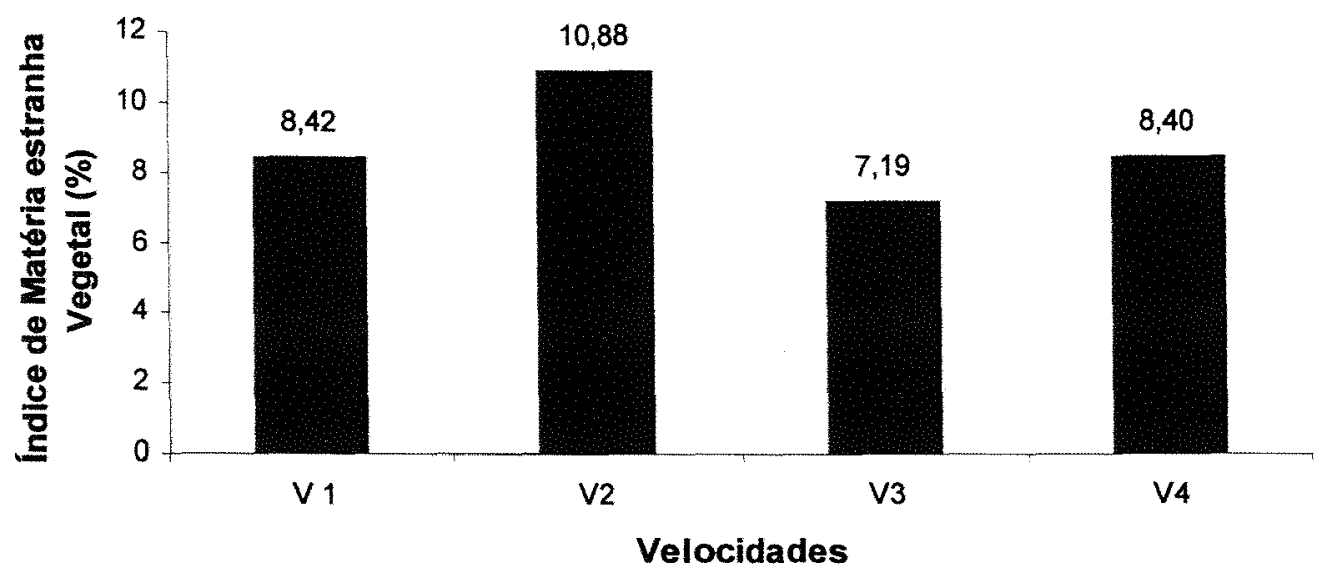

Figura 32. Índice de Matéria Estranha Vegetal encontrada na matéria prima colhida.

\subsection{6 Índice de Matéria Estranha Mineral - IM (\%)}

A Matéria Estranha Mineral encontrada na matéria-prima, obteve na análise estatística valor de $\mathrm{F}$ significativo ao nível de $5 \%$ de probabilidade, conforme apresentado na Tabela 35 .

Com a aplicação do teste Tukey ao nível de $1 \%$ de probabilidade não se constatou diferenças significativas entre as médias. Porém ao nível de $5 \%$ de probabilidade as velocidades $\mathrm{V} 4 \mathrm{e} \mathrm{V} 2$, apresentaram diferenças significativas maiores, quando comparada com as velocidades V1 e V3, apresentado na Tabela 36. A velocidade V3 obteve Índice de Matéria Estranha Mineral mais baixo que na velocidade V2 como mostra a Figura 33, como a máquina nesta velocidade operou com o cortador de base mais alto, consequentemente levou menor quantidade de terra junto com a matéria-prima . Os valores encontrados na velocidade V3 são próximos aos encontrados por Fernandes \& Irvine (1986) 0,3\%, John (1992) 0,3 e 0,2\% Lima (1994) 0,2\%, Fulani Neto (1995) 0,46\%, Moraes \& Neves (1997b) 0,1 a 0,5, Strini Jr.(1999) 0,5\%. Menores que os encontrados por Norris et al.(1998) 0,4 a 2,9\%, Arruda Pinto \& Nunes Jr. (1998) $1,10 \%$ em canaviais sem queima prévia. Nas quatro velocidade estudadas os valores não confirmam os obtidos por Roseff (1989). 


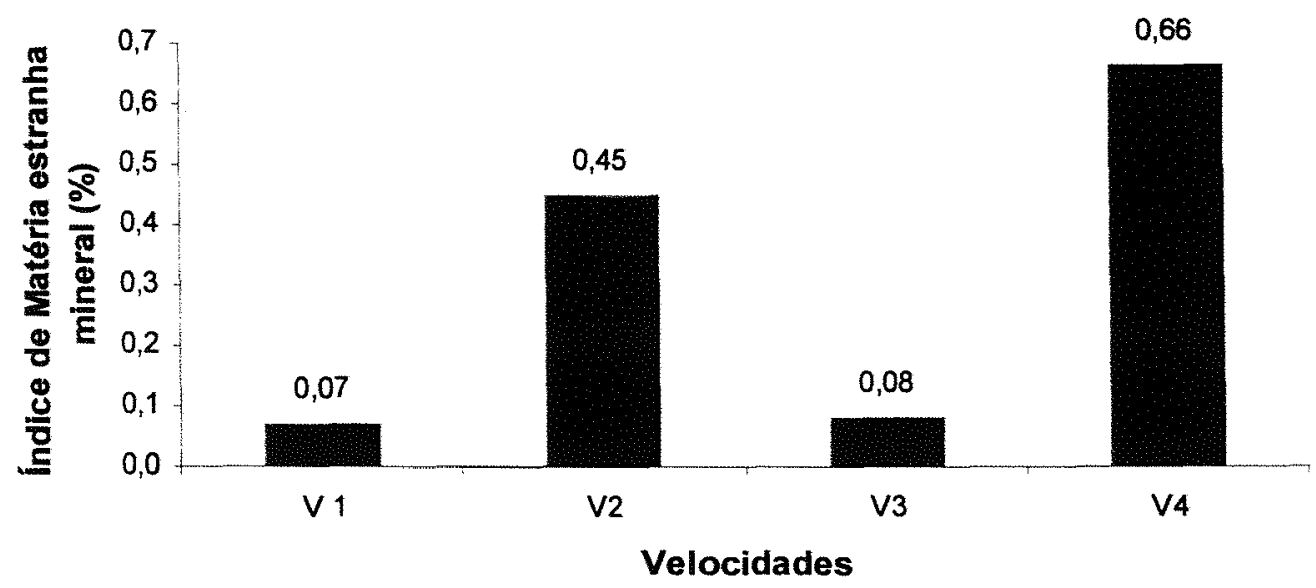

Figura 33. Índice de Matéria Estranha Mineral contida no produto colhido.

\subsection{7 Índice de Matéria Estranha Total - IT (\%)}

O Índice de Matéria Estranha Total, não apresentou significância estatística quando se aplicou o teste $\mathrm{F}$, ao nível de $5 \%$ de probabilidade (Tabela 37). Pode-se afirmar com este comportamento que o aumento da velocidade de avanço da colhedora não provocou aumento da matéria estranha na matéria-prima, embora as variáveis Índice de Folhas, Índice de Raízes e Índice de Matéria Estranha Mineral fossem influenciadas pelo aumento da velocidade. Mesmo não tendo diferença significativas, a velocidade V2 apresentou em média quantidade de matéria estranha total superior que as demais velocidades estudadas (Figura 34). Estes resultados não confirmam a tendência proposta por Roseff (1989), em que a matéria estranha aumenta com a elevação da velocidade de deslocamento da colhedora, onde o mesmo apresentou valores variando de 5,5 a 21,0\% para uma elevação de velocidade de 1,42 a $5,63 \mathrm{~km} \cdot \mathrm{h}^{-1}$ respectivamente. Os valores obtidos são diferentes dos encontrados em canaviais sem queima prévia por Herreira \& Linares (1986) 10,0\%, Shaw \& Brotherton (1992) 4,42\%, Dick \& Greves-James (1992) 5,1 a 16,1\%, Arruda Pinto \& Nunes Jr.(1998) 6,60\%, Lima (1994) 5,5\%, Smith et al (1985) 7,41 a 8,24\%, Romero et al. (1993) 5,3 a 13\%, Scandalares et al. (1997) 5,5 a $6,5 \%$, Hurney et al. (1994) 1,8 a 4,2\%. Valores foram iguais aos encontrados por 
Cenicaña (1995) 9,82\%, Furlani Neto (1995) 6,05 a $11,60 \%$, Cenicaña (1996) $10,3 \%$, Cenicaña (1997b) 11,73\%, Cenicaña (1997a) 8,3\%, Norris et al. (1998) 2,6 a 7,1\%, também em canaviais sem queima prévia.

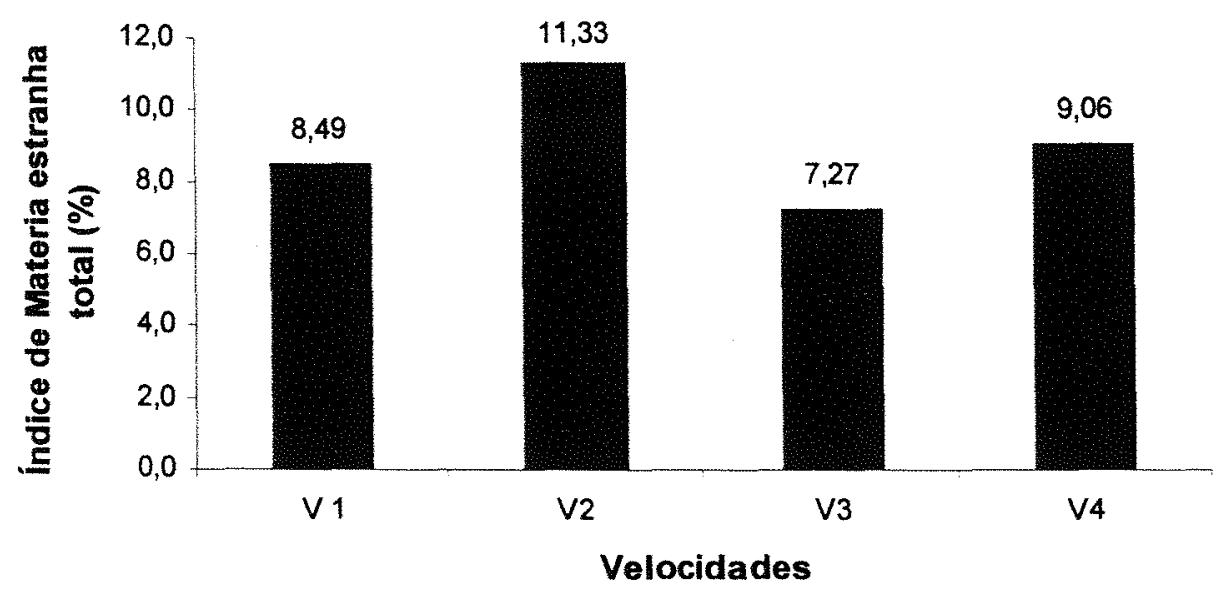

Figura 34. Índice de Matéria Estranha Total encontrada na matéria-prima.

Os resultados médios da matéria estranha contida na matéria-prima provocada pela colhedora nas quatro velocidades estudadas, estão resumidos na Tabela 38.

Tabela 38. Resumo dos resultados médios da matéria estranha contida na matéria-prima.

\begin{tabular}{cccccccc}
\hline & IP (\%) & IF (\%) & IP (\%) & IR (\%) & IV (\%) & IM (\%) & IT (\%) \\
Veloc. & & & & & & & \\
\hline V1 & 7,06 & 0,38 & 0,86 & 0,12 & 8,42 & 0,07 & 8,49 \\
V2 & 6,72 & 1,12 & 0,67 & 2,37 & 10,88 & 0,45 & 11,33 \\
V3 & 4,38 & 1,85 & 0,81 & 0,15 & 7,19 & 0,08 & 7,27 \\
V4 & 5,25 & 1,16 & 1,26 & 0,73 & 8,40 & 0,66 & 9,06 \\
\hline
\end{tabular}

$\mathrm{IP}=$ Índice de Ponteiros. $\mathrm{IP}=$ Índice Folhas. $\mathrm{IP}=$ Índice de Palhas. $\mathrm{IR}=$ Índice de Raízes. IV = Índice de Matéria Estranha Vegetal. IM = Índice de Matéria Estranha Mineral. IT = Índice de Matéria Estranha Total. 


\subsection{Qualidade tecnológica da matéria-prima}

As análises tecnológicas efetuadas, não apresentaram diferenças significativas com a aplicação do teste $\mathrm{F}$, ao nível de $5 \%$ de probabilidade (Tabela 39). Pelas Figuras 35 e 36, nota-se que houve diminuição do Brix (\%) do caldo e aumento na quantidade de terra com a elevação da velocidade. Os valores médios encontrados para variável terra, mostraram diferenças altas mas não foram significativas, pois apresentaram coeficiente de variação de $58,99 \%$. Os resultados médios encontrados nas análises tecnológicas estão próximos aos níveis aceitáveis descritos por Stupiello (1996) Brix caldo 18\%, Pol caldo 14,4 a $15,3 \%$, Pureza 80 a $85 \%$. O aumento nos valores médios da quantidade de terra não alterou a fibra da cana, obtendo-se um comportamento diferente do encontrado por Fors \& Arias (1977) onde o aumento em $1 \%$ na quantidade de terra acrescentou 0,30 o teor de fibra da cana. Os valores obtidos, são diferentes dos encontrados por Furlani Neto (1995) para Brix caldo, 21,50 a 21,96\%, Pol caldo 18,56 a 20,30\%, Pureza caldo 86,28 a $92,44 \%$, Fibra cana 14,83 a $18,77 \%$ e iguais para Pol cana corrigido 14,54 a $15,23 \%$. 


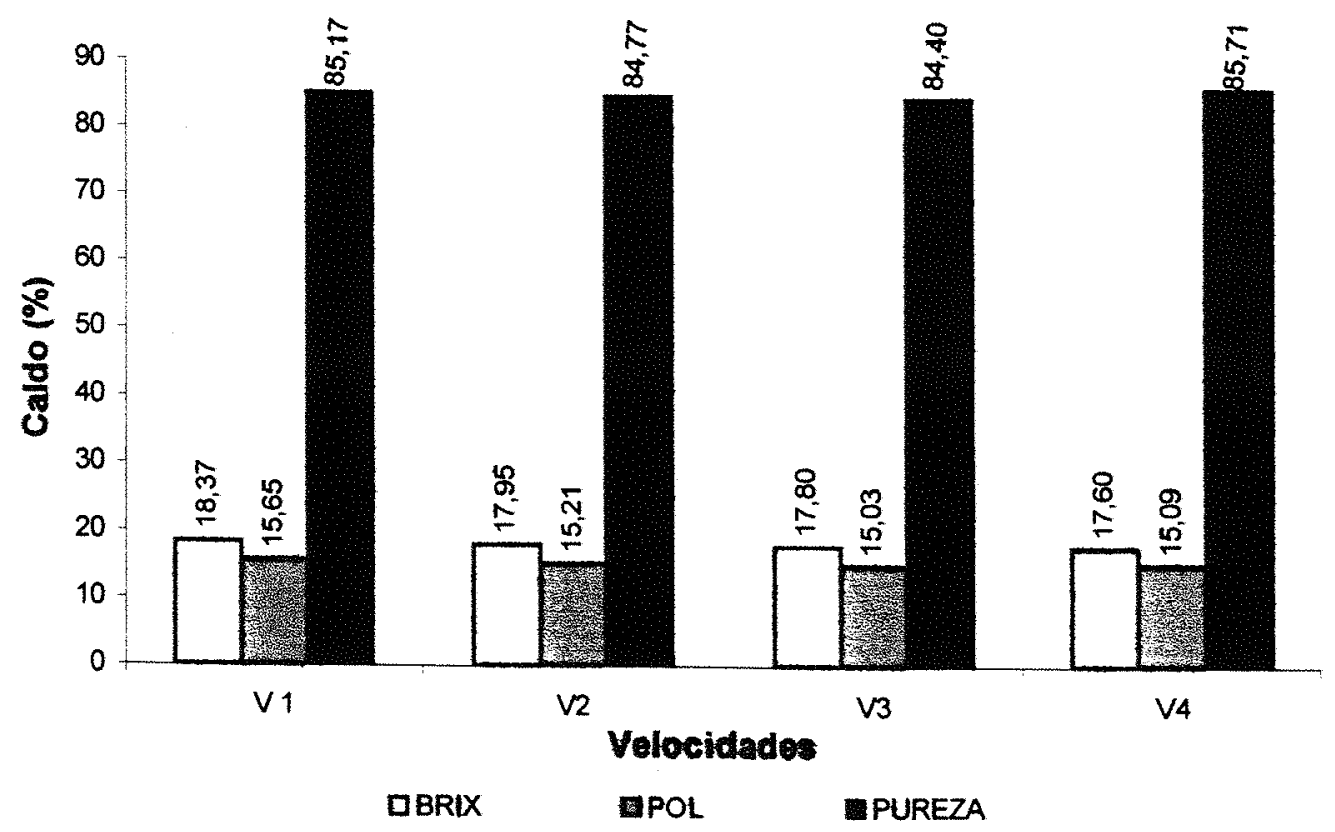

Figura 35.Resultados de Brix (\%), Pol (\%) e Pureza (\%) do caldo nas quatro velocidades estudadas.

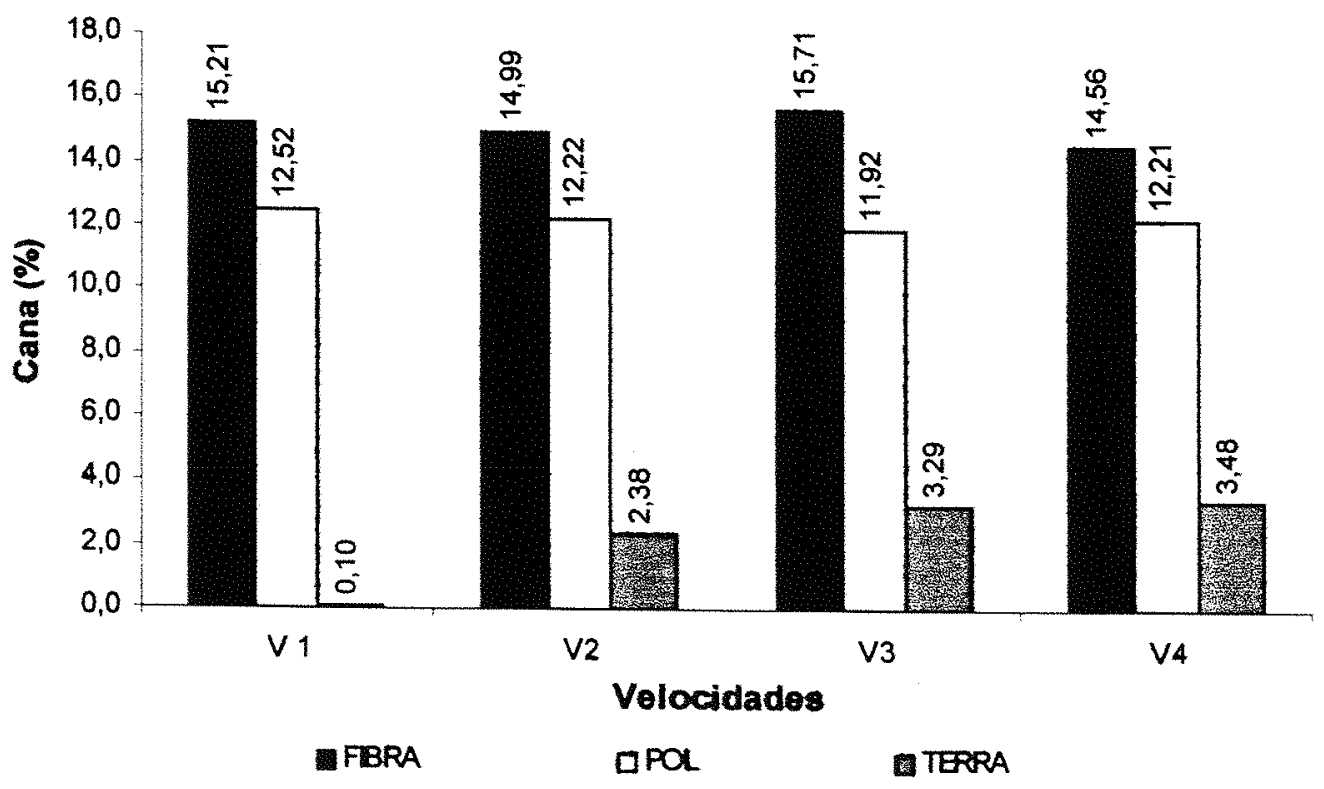

Figura 36. Resultados de fibra (\%), Pol (\%) da cana e terra para as quatro velocidades estudadas. 


\subsection{Freqüência de comprimento dos rebolos}

As velocidades V3 e V4 representadas nas Figuras 37 e 38, apresentam a maior freqüência no comprimento dos rebolos entre 19 a 25 centímetros, o que caracterizou uma menor variabilidade na freqüência do comprimento dos rebolos entre as velocidades estudadas. Nas velocidades V1 e V2 a variabilidade na freqüência do comprimento dos rebolos foram maiores, sendo que as maiores freqüências nos comprimentos dos rebolo foram em torno de 19 a 35 centímetros (Figuras 39 e 40). Para Vitale \& Domante (1997) e Fuellig (1982), o tamanho ótimo do comprimento dos rebolos ficam em torno de 20 a 25 centímetros, pois pode diminuir a deterioração, a matéria estranha, as perdas e o custo com transporte, baseando-se nesta proposição as velocidades V3 e V4 apresentaram os melhores comportamentos para as condições analisadas. Os resultados obtidos nas velocidades V1, V2 e V3 foram diferentes dos encontrados por Roseff (1989). Nas velocidadesV3 e V4 os valores foram menores que os encontrados por Norris et al. (1998), em canaviais sem queima prévia.

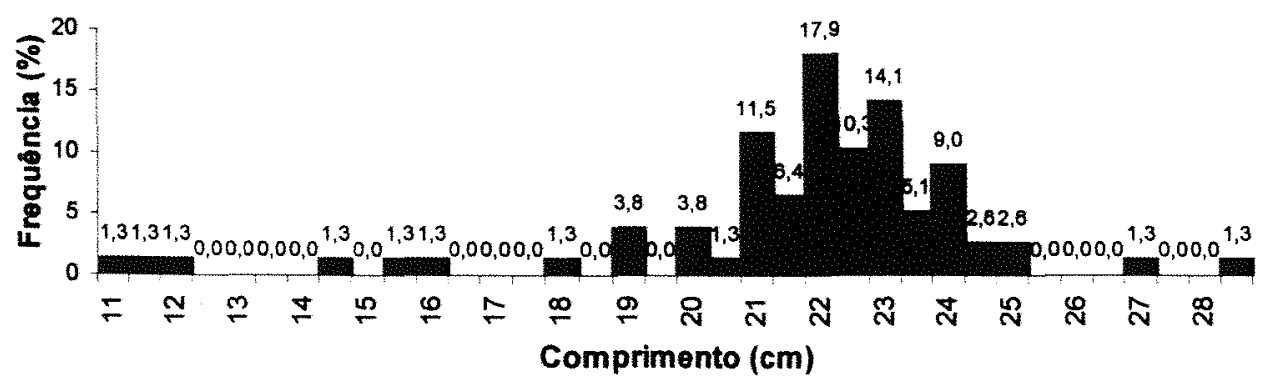

Figura 37. Freqüência de comprimento dos rebolos obtidos na velocidade V3. 


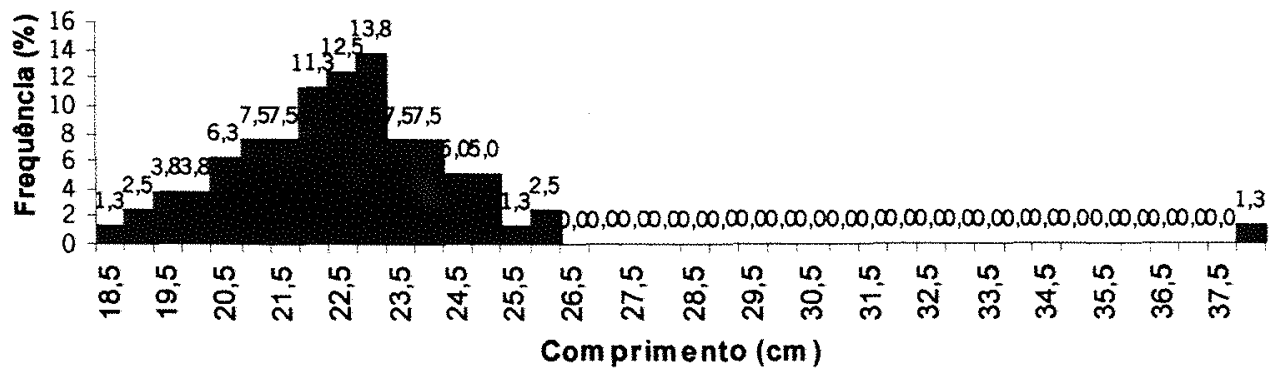

Figura 38. Frequiência de comprimento dos rebolos obtidos na velocidade V4.

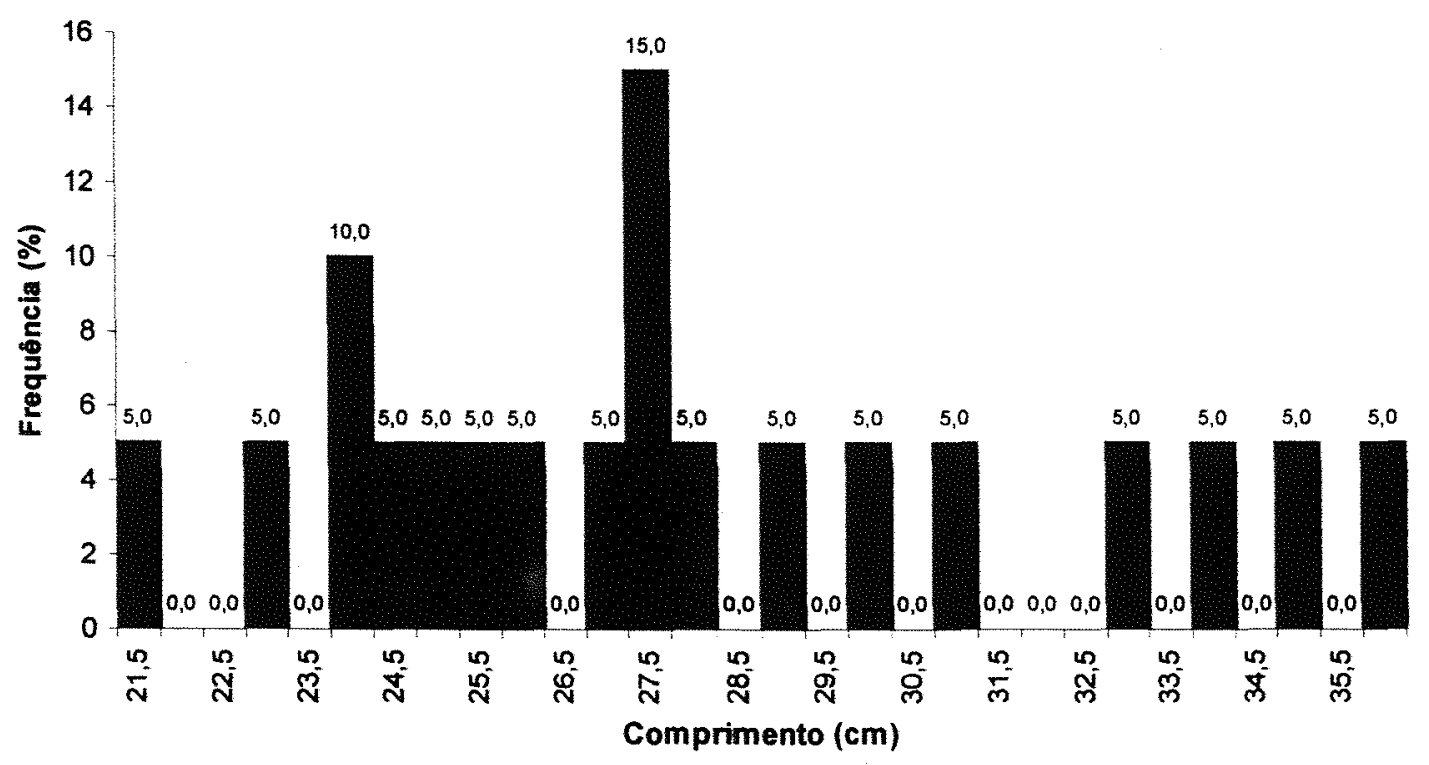

Figura 39. Freqüência de comprimento dos rebolos obtidos na velocidade V1. 


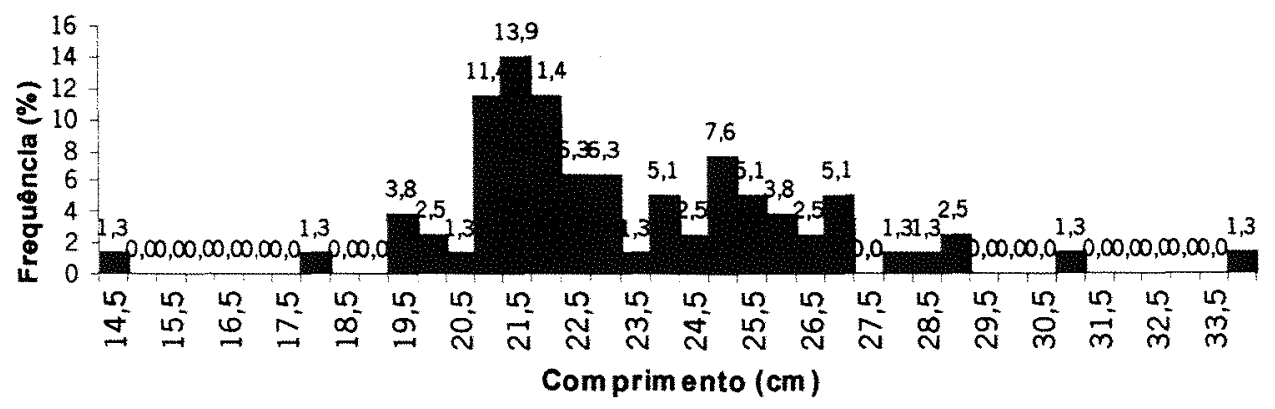

Figura 40. Frequiência de comprimento dos rebolos obtidos na velocidade V2.

\subsection{1 Índice de cisalhamento dos rebolos}

Ao se analisar as características dos cisalhamentos dos rebolos observou-se que as velocidades V1 e V3 (Figuras 41 e 42), quando comparados com as velocidades V2 e V4 (Figuras 43 e 44), apresentaram menores índices de cisalhamentos. Rebolos macerados em ambas extremidades podem contribuir para a deterioração mais rápida da matéria-prima, (Fuelling, 1982). Os resultados encontrados estão abaixo dos valores recomendados por Ripoli (1996), ou sejam $95 \%$ de rebolos com cisalhamento adequado o que caracteriza então que a máquina em estudo não apresentou sincronismo adequado entre a velocidade angular desse órgão e a velocidade com que os colmos atravessam a lâmina cortante. Os valores encontrados nas velocidades V2, V3 e V4 são diferentes dos encontrados por Norris et al. (1998). Nas velocidades V1, V2 e V3 os resultados não confirmam os encontrados por Roseff (1989) em canaviais sem queima prévia. 


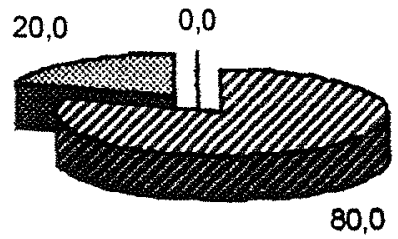

Perfeito

M Macerado 1 extremidade

$\square$ Macerado 2 extremidades

80,0

Figuras 41. Características dos cisalhamentos dos rebolos em (\%), na velocidade V1.

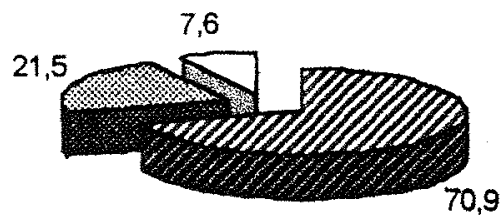

DPerfeito

a Macerado 1 extremidade

$\square$ Macerado 2 extremidades

Figura 42. Características dos cisalhamentos dos rebolos em (\%), na velocidade V3.

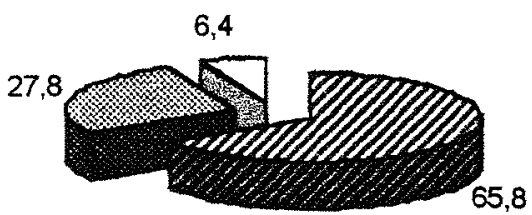

a Perílto

Macerado 1 extremidade

$\square$ Macerado 2 extremidades

Figuras 43. Características dos cisalhamentos dos rebolos em (\%), na velocidade V2. 

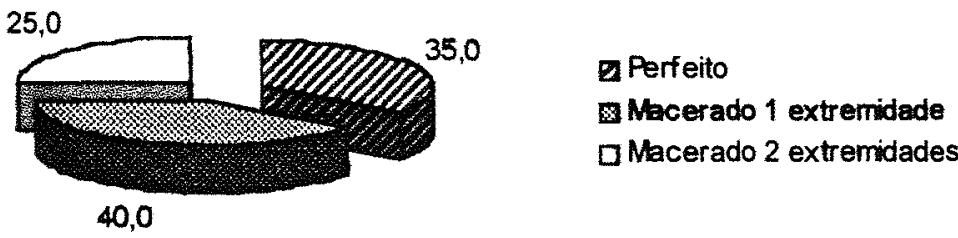

Figura 44. Características dos cisalhamentos dos rebolos em (\%), na velocidade V4.

\subsection{Análise do desempenho econômico}

A partir dos dados dos custos de peças para reposição e filtros fornecidos pelas usinas ao longo de sete anos, foi efetuada a análise de desempenho econômico da colhedora (Figura 45), observou-se que os custos referentes as essas variáveis no $1^{\circ}, 2^{\circ}$, $3^{\circ}, 5^{\circ}$ e $6^{\circ}$ ano foram semelhantes. No $4^{\circ}$ ano o custo foi alto, devido a reposição da esteira, e os seguintes componentes dos motores: camisas, êmbolos, anéis, revisão da bomba e bicos injetores. Como no momento não existe demanda de mercado para este tipo de máquina, deve se propor a reforma, caso haja demanda de mercado, este seria o momento ideal para a venda da máquina devido ao elevado custo de manutenção, conforme conceito proposto por Noronha et al.(1991). No $7^{\circ}$ ano o custo de manutenção chega a US\$ 67.969,69 em decorrência da retifica completa do motor, reparos dos mecanismos de transmissão, bombas, bicos injetores e a esteira da colhedora. Neste momento os custos chegaram ao dobro do valor da máquina. Em conseqüência disto a análise econômica da colhedora foi determinada para seis anos de utilização, ou seja 18.000 horas de vida útil, sendo 3.000 horas por ano ou safra. No caso específico desta colhedora, recomenda-se fazer no $7^{0}$ ano a reforma total, pois com a soma os custos da reforma mais os $10 \%$ do valor de sucata, poderia obter uma máquina pelo valor de US\$ 94.669,69 que quando comparado com o valor de uma máquina nova, há uma diminuição no custo de aquisição na ordem de US\$172.330,31. 


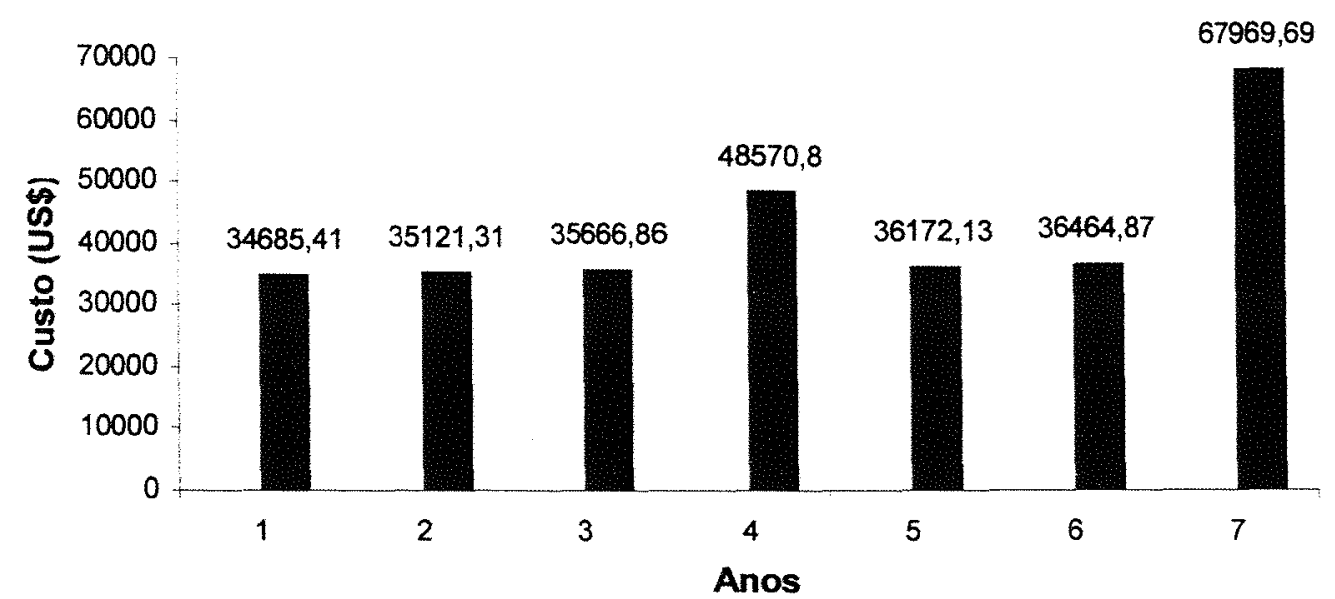

Figura 45. Custos anuais com peças de reposição e filtros em sete anos de uso, segundo dados fornecidos por Usinas do Estado de São Paulo.

\subsubsection{Custo operacional da colhedora}

As Tabelas 40 a 56 apresentam as estimativas dos custos ao longo dos 6 anos para as 16 capacidades operacionais, constituindo-se em 16 fluxos de caixa para a colhedora em estudo. O custo-hora da colhedora foi determinado pela somatória de todas as despesas ao longo da vida útil dividida pelas 18.000 horas de operação.

A partir do custo-hora da máquina e das quatro Capacidades Efetivas Brutas determinadas no ensaio multiplicadas pelas Eficiências de Campo de 45, 55, 65 e 75\%, elaborou-se os diversos cenários com varias possibilidades de desempenho econômico, conforme apresentados nas Figuras 46 e 47. 


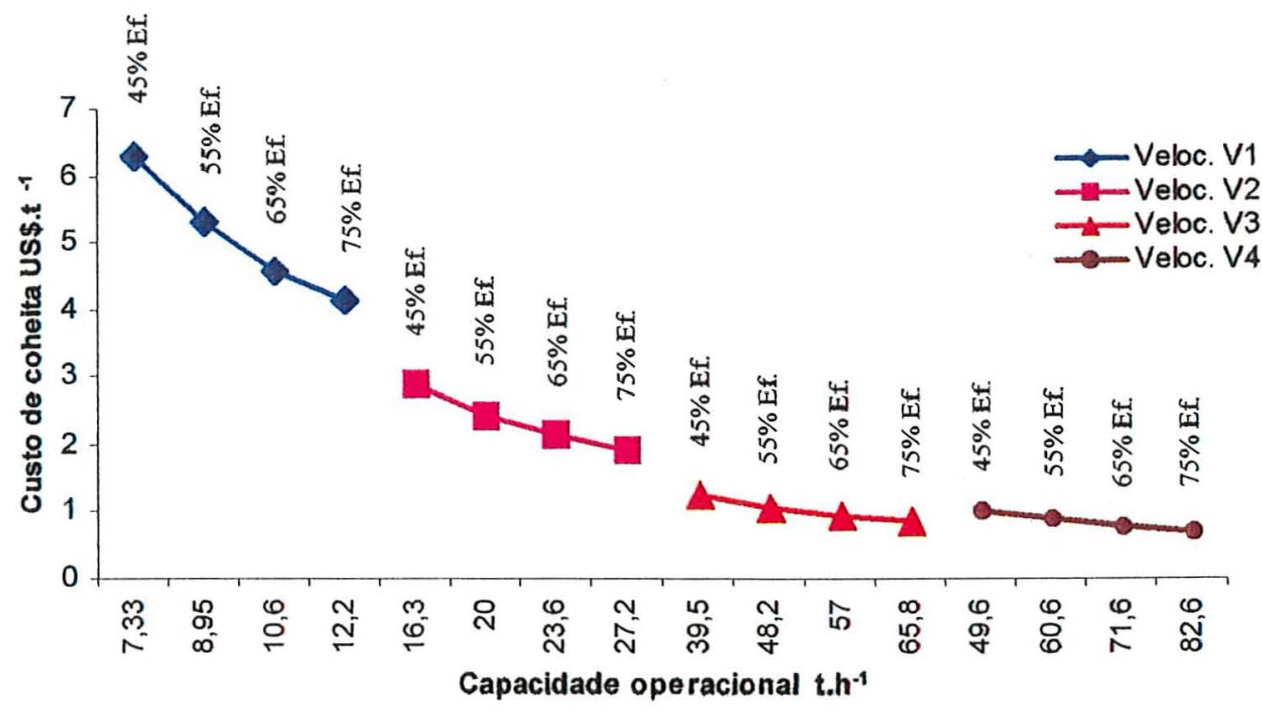

Figura 46. Estimativas dos custos da colhedora para as 16 Capacidades Operacionais com base em 4 diferentes Eficiências de Campo.

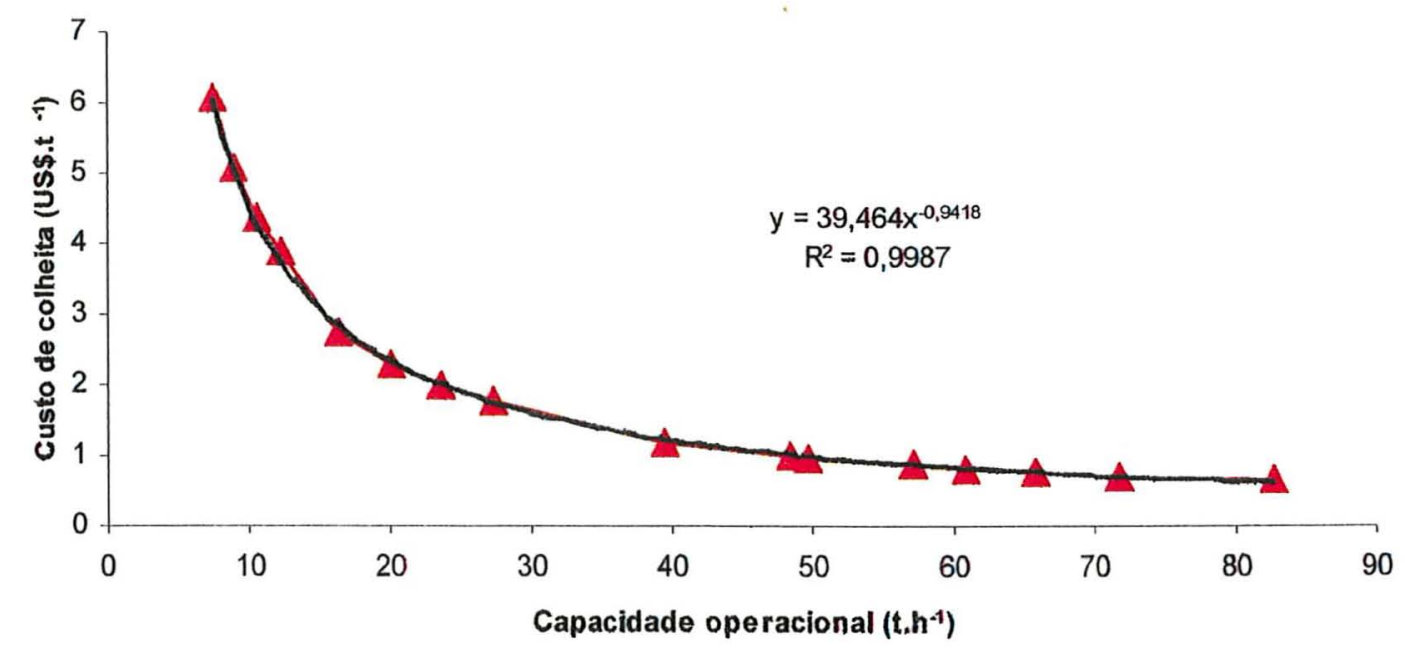

Figura 47. Relação entre a Capacidade Operacional e o custo por tonelada colhida.

Analisando-se as Figuras 46 e 47 verifica-se que a máquina estudada apresentou custos de colheita variando de US\$.t ${ }^{-1} 0,65$ a 6,07 . A velocidade de colheita V1, nas quatro eficiências de campo, os custos oscilaram em US\$.t ${ }^{-1}$ 3,90 a 6,07, sendo praticamente inviável economicamente, devido ao seu alto custo de colheita. Na 
velocidade V2 os custos variaram de US\$.t $\mathrm{t}^{-1} 1,76$ a 2,73 sendo que os custos menores foram nas Eficiência de Campo 65 e $75 \%$ variando de US\$.t $\mathrm{U}^{-1} 1,99$ a 1,76. Já as velocidades V3 e V4 nas quatro Eficiências de Campo apresentaram os menores custos,

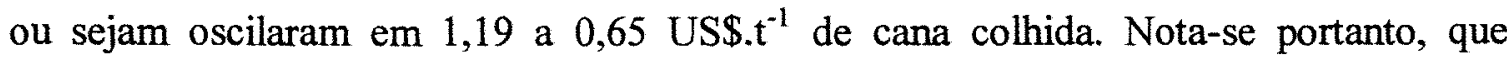
mesmo com altas capacidades efetivas é necessário que se tenha preocupação com os aspectos relacionados a eficiência, pois este fator esta associados com a logística gerencial do sistema de colheita, uma vez que talhões sistematizados, quantidade suficiente de veículos de transbordo e de transporte com finalidade de evitar as perdas de tempo, determinam a capacidade operacional que quanto maior, menor será o custo de colheita, podendo desta forma viabilizar economicąmente o subsistema de colheita mecânica em cana crua. Os custos encontrados para a colhedora estudada, confirmam os encontrados por: Broussard (1987) US\$.t t $^{-1}$ 0,80 a 10,50, Mialhe \& Ripoli (1983) US\$.t ${ }^{-1}$ 0,52 a 0,73 , Lima (1998) US\$.t ${ }^{-1} 1,77$ a 3,71, Relatório técnico (1998) US\$.t ${ }^{-1} 1,56$, Boletim técnico (1998) US\$.t ${ }^{-1} 1,19$, Kronka \& Monteiro (1999) US\$.t $\mathrm{t}^{-1}$ 2,44, Strini Jr. US $\$ . t^{-1} 1,23$, Cury (1999) US\$.t $\mathrm{U}^{-1}$ 0,52, neste último caso somente os custos operacionais. 


\section{CONCLUSÕES}

Face aos resultados obtidos e as discussões efetuadas, pode-se concluir que:

Houve um aumento nas Capacidades Efetiva Bruta e Operacional, à medida que se elevou a velocidade de deslocamento da colhedora;

O Consumo de Combustível por tonelada de cana colhida diminuiu com o aumento da velocidade;

As perdas totais de matéria-prima no campo não aumentaram com a elevação da velocidade de deslocamento da colhedora. Porém, as perdas na forma de rebolos e de frações de colmos foram influenciadas negativamente pelo aumento da velocidade da colhedora;

A quantidade de matéria estranha total encontrada na matéria-prima não aumentou com a elevação da velocidade de deslocamento da colhedora, mesmo sendo constatadas diferenças significativas da velocidade de avanço sobre os Índices de Folha, Raízes e Matéria Estranha Mineral;

A elevação da velocidade de avanço da colhedora provocou aumento na quantidade de raízes arrancadas;

O aumento da velocidade de trabalho não influenciou a qualidade tecnológica da matéria-prima colhida;

$\mathrm{O}$ custo da tonelada de cana colhida diminuiu à medida que a velocidade de deslocamento aumentou;

Os melhores desempenhos econômicos obtidos foram nas velocidades V2, quando estimou-se as Eficiências de Campo de 65 e 75\%, e nas velocidades V3 e V4 nas quatro Eficiências de Campo estudadas; 
A relação obtida entre a Capacidade Operacional e o Custo por tonelada de cana colhida apresentou um coeficiente de correlação aceitável para este tipo de estudo. 
Anexo 
Tabela 1. Valores médios encontrados no canavial, antes da colheita, para colmos, ponteiros, folhas verdes e palhas $\left(\mathrm{t} \cdot \mathrm{ha}^{-1}\right)$.

\begin{tabular}{lccc}
\hline \multicolumn{1}{c}{ Parâmetros } & Média & Desvio padrão & Int. Conf. \\
\hline Ponteiros & 6,56 & 2,32 & 1.31 \\
Folhas verdes & 14,08 & 3,63 & 2,05 \\
Palhas & 10,23 & 2,49 & 1,41 \\
Colmos & 145,39 & 38,85 & 21,64 \\
Massa total & 176,26 & - & - \\
\hline
\end{tabular}

Médias referentes a 12 coletas na área de estudo. Int. Conf. = Intervalo de confiança.

Tabela 2. Quantidade média de colmos nas 16 repetições do ensaio (t.ha ${ }^{-1}$ ).

\begin{tabular}{ccc}
\hline Discriminação & Média & Desvio padrão \\
\hline Cana rebolos + perdas & 100,56 & 16 \\
\hline
\end{tabular}

Média de colmos colhidos pela máquina somada as perdas no campo.

Tabela 3 Resumo da análise da variância, para a variável peso da matéria-prima colhida nas 16 repetições.

\begin{tabular}{ccc}
\hline C. V. & G. L. & Q. M. \\
\hline Velocidade & 3 & $1,5789(0,17258)^{* *}$ \\
Resíduo & 12 & 0,8035725 \\
\hline
\end{tabular}

** Não significativo ao nível de $5 \%$ de probabilidade.

Tabela 4. Resultado da determinação do porte do canavial, nas 12 repetições.

\begin{tabular}{lcc}
\hline \multicolumn{1}{c}{ Modalidades } & Média (\%) & C. V. (\%) \\
\hline Ereto & 83,98 & 10,02 \\
Acamado & 11,65 & 85,26 \\
Deitado & 4,37 & 120,09 \\
\hline
\end{tabular}

Tabela 5. Comprimento médio dos colmos, média de 13 repetições.

\begin{tabular}{cc}
\hline Média $(\mathrm{m})$ & Desvio Padrão \\
\hline 3,26 & 4,1 \\
\hline
\end{tabular}


Tabela 6. Resumo da análise da variância para a variável Velocidade média.

\begin{tabular}{ccc}
\hline C. V. & G.L. & Q.M. \\
\hline Velocidade & 3 & $31,7552(0,00001)^{*}$ \\
Resíduos & 12 & 0,1383 \\
\hline
\end{tabular}

* Significativo ao nível de $5 \%$ de probabilidade.

Tabela 7. Teste Tukey para a Velocidade média.

\begin{tabular}{cccc}
\hline Velocidade & Médias $\left(\mathrm{km} \cdot \mathrm{h}^{-1}\right)$ & $5 \%$ & $1 \%$ \\
\hline V4 & 7,68 & $\mathrm{a}$ & $\mathrm{A}$ \\
V3 & 5,27 & $\mathrm{~b}$ & $\mathrm{~B}$ \\
V2 & 2,66 & $\mathrm{c}$ & $\mathrm{C}$ \\
V1 & 1,34 & $\mathrm{~d}$ & $\mathrm{D}$
\end{tabular}

Médias seguidas por letras distintas diferem entre si ao nível de significancia indicado.

Tabela 8. Resumo da análise da variância para Capacidade Efetiva Bruta.

\begin{tabular}{ccl}
\hline C. V. & G. L. & \multicolumn{1}{c}{ Q. M. } \\
\hline Velocidade & 3 & $7638,9418(0,00002)^{*}$ \\
Resíduo & 12 & 167,5582 \\
\hline
\end{tabular}

* Significativo ao nível de $5 \%$ de probabilidade.

Tabela 9. Teste Tukey para Capacidade Efetiva Bruta.

\begin{tabular}{cccc}
\hline Velocidade. & Médias $\left(\mathrm{t} . \mathrm{h}^{-1}\right)$ & $5 \%$ & $1 \%$ \\
\hline V4 & 110,18 & $\mathrm{a}$ & $\mathrm{A}$ \\
V3 & 87,67 & $\mathrm{a}$ & $\mathrm{A}$ \\
V2 & 36,29 & $\mathrm{~b}$ & $\mathrm{~B}$ \\
V1 & 16,29 & $\mathrm{~b}$ & $\mathrm{~B}$
\end{tabular}

Médias seguidas por letras distintas diferem entre si ao nível de significância indicado. 
Tabela 10. Resumo da análise da variância para a variável Eficácia de Manipulação.

\begin{tabular}{ccc}
\hline C. V. & G. L. & \multicolumn{1}{c}{ Q. M. } \\
\hline Velocidade & 3 & $0,0013165(0,32980)^{* *}$ \\
Resíduo & 12 & 0,0010390 \\
\hline
\end{tabular}

**Não significativo ao nível de $5 \%$ de probabilidade.

Tabela 11. Resumo da análise da variância para Capacidade Efetiva Líquida.

\begin{tabular}{ccl}
\hline C. V. & G. L. & \multicolumn{1}{c}{ Q. M. } \\
\hline Velocidade & 3 & $6211,5736(0,00002)^{*}$ \\
Resíduo & 12 & 161,5979 \\
\hline
\end{tabular}

* Significativo ao nível de $5 \%$ de probabilidade.

Tabela 12. Teste Tukey para a Capacidade Efetiva Líquida.

\begin{tabular}{cccc}
\hline Velocidade. & Médias $\left(\mathrm{t} \cdot \mathrm{h}^{-1}\right)$ & $5 \%$ & $1 \%$ \\
\hline V4 & 100,34 & $\mathrm{a}$ & $\mathrm{A}$ \\
V3 & 79,01 & $\mathrm{a}$ & $\mathrm{A}$ \\
V2 & 33,61 & $\mathrm{~b}$ & $\mathrm{~B}$ \\
V1 & 15,18 & $\mathrm{~b}$ & $\mathrm{~B}$
\end{tabular}

Médias seguidas por letras distintas diferem entre si ao nível de significância indicado.

Tabela 13. Resumo da análise da variância da interação entre a velocidade e o consumo de combustivel $\left(\mathrm{l} . \mathrm{t}^{-1}\right)$.

\begin{tabular}{ccl}
\hline C. V. & G. L. & \multicolumn{1}{c}{ Q. M. } \\
\hline Velocidade & 3 & $0,5336(0,00015)^{*}$ \\
Resíduo & 10 & 0,0202 \\
\hline
\end{tabular}

* Significativo ao nível de $5 \%$ de probabilidade. 
Tabela 14. Resumo da análise da variância da interação entre a velocidade e o consumo de combustível $\left(1 . \mathrm{h}^{-1}\right)$.

\begin{tabular}{ccl}
\hline C. V. & G. L. & \multicolumn{1}{c}{ Q.M. } \\
\hline Velocidade & 3 & $341,1567(0,00004)^{*}$ \\
Resíduo & 10 & 7,3065 \\
\hline
\end{tabular}

* Significativo ao nível de $5 \%$ de probabilidade.

Tabela 15. Teste Tukey, para a interação entre a velocidade e o consumo de combustível $\left(1 . t^{-1}\right)$.

\begin{tabular}{cccc}
\hline Velocidade & Médias $\left(1 . t^{-1}\right)$ & $5 \%$ & $1 \%$ \\
\hline V1 & 2,92 & $\mathrm{a}$ & $\mathrm{A}$ \\
V2 & 1,25 & $\mathrm{~b}$ & $\mathrm{~B}$ \\
V3 & 0,69 & $\mathrm{~b}$ & $\mathrm{~B}$ \\
V4 & 0,61 & $\mathrm{~b}$ & $\mathrm{~B}$
\end{tabular}

Médias seguidas por letras distintas diferem entre si ao nível de significância indicado

Tabela 16. Teste Tukey, para a interação entre a velocidade e o consumo de combustível, $\left(1 . h^{-1}\right)$.

\begin{tabular}{cccc}
\hline Velocidade & Médias $\left(1 . \mathrm{h}^{-1}\right)$ & $5 \%$ & $1 \%$ \\
\hline V4 & 66,27 & $\mathrm{a}$ & $\mathrm{A}$ \\
V3 & 60,04 & $\mathrm{~b}$ & $\mathrm{~A}$ \\
V2 & 49,77 & $\mathrm{c}$ & $\mathrm{B}$ \\
V1 & 45,28 & $\mathrm{c}$ & $\mathrm{B}$ \\
\hline
\end{tabular}

Médias seguidas por letras distintas diferem entre si ao nível de significaria indicado.

Tabela 18. Resumo da análise da variância para perda de colmos e frações de colmos.

\begin{tabular}{ccl}
\hline C.V. & G. L. & \multicolumn{1}{c}{ Q. M. } \\
\hline Velocidade & 3 & $20,7329(0,32366)^{* *}$ \\
Residuo & 12 & 16,1148 \\
\hline
\end{tabular}

**Não significativo ao nível de $5 \%$ de probabilidade. 
Tabela 19. Resumo da análise da variância para as perdas na forma de rebolos.

\begin{tabular}{ccl}
\hline C. V. & G. L. & \multicolumn{1}{c}{ Q. M. } \\
\hline Velocidade & 3 & $38,9573(0,00001)^{*}$ \\
Resíduo & 12 & 0,4678 \\
\hline
\end{tabular}

* Significativo ao nível de $5 \%$ de probabilidade.

Tabela 20. Teste Tukey, para as perdas na forma de rebolos.

\begin{tabular}{cccc}
\hline Velocidade & Médias (\%) & $5 \%$ & $1 \%$ \\
\hline V3 & 6,24 & $\mathrm{a}$ & $\mathrm{A}$ \\
V2 & 0,00 & $\mathrm{~b}$ & $\mathrm{~B}$ \\
V1 & 0,00 & $\mathrm{~b}$ & $\mathrm{~B}$ \\
V4 & 0,00 & $\mathrm{~b}$ & $\mathrm{~B}$ \\
\hline
\end{tabular}

Médias seguidas por letras distintas diferem entre si ao nível de significância indicado.

Tabela 21. Resumo da análise da variância para as perdas na forma de frações de rebolos.

\begin{tabular}{ccl}
\hline C.V. & G.L. & \multicolumn{1}{c}{ Q. M. } \\
\hline Velocidade & 3 & $0,7137897(0,95223)^{* *}$ \\
Resíduo & 12 & 6,517574 \\
\hline
\end{tabular}

**Não significativo ao nível de $5 \%$ de probabilidade.

Tabela 22. Resumo da análise da variância para as perdas na forma de frações de colmos na soqueira.

\begin{tabular}{ccl}
\hline C. V. & G.L. & \multicolumn{1}{c}{ Q.M. } \\
\hline Velocidade & 3 & $49,1562(0,00292)^{*}$ \\
Resíduos & 12 & 5,7224 \\
\hline
\end{tabular}

* Significativo ao nível de $5 \%$ de probabilidade. 
Tabela 23 Teste Tukey para as perdas na forma de frações de colmos na soqueira.

\begin{tabular}{cccc}
\hline Velocidade & Medias (\%) & $5 \%$ & $1 \%$ \\
\hline V3 & 3,93 & $\mathrm{a}$ & $\mathrm{A}$ \\
V4 & 2,10 & $\mathrm{Ab}$ & $\mathrm{AB}$ \\
V1 & 0,85 & $\mathrm{~b}$ & $\mathrm{AB}$ \\
V2 & 0,36 & $\mathrm{~b}$ & $\mathrm{~B}$ \\
\hline
\end{tabular}

Medias seguidas por letras distintas difere entre si ao nível de significância indicado.

Tabela 24. Resumo da análise da variância para a variável raízes arrancadas pela máquina.

\begin{tabular}{ccl}
\hline C.V & G.L & \multicolumn{1}{c}{ Q.M. } \\
\hline Velocidade & 3 & $24,780350(0,02241)^{*}$ \\
Resíduos & 12 & 5,3558 \\
\hline
\end{tabular}

*Significativo ao nível de $5 \%$ de probabilidade

Tabela 25. Teste Tukey para a variável raízes arrancadas pela máquina.

\begin{tabular}{cccc}
\hline Velocidade & ${\text { Médias }\left(\mathrm{t}^{-h^{-1}}{ }^{-1}\right)}$ & $5 \%$ & $1 \%$ \\
\hline V4 & 0,90 & $\mathrm{a}$ & $\mathrm{A}$ \\
V2 & 0,58 & $\mathrm{ab}$ & $\mathrm{A}$ \\
V3 & 0,08 & $\mathrm{ab}$ & $\mathrm{A}$ \\
V1 & 0,00 & $\mathrm{~b}$ & $\mathrm{~A}$ \\
\hline
\end{tabular}

Médias seguidas por letras distintas diferem entre si ao nível da significância indicada.

Tabela 26. Resumo da análise da variância para a variável perdas totais de matéria-prima.

\begin{tabular}{ccl}
\hline C. V. & G. L. & \multicolumn{1}{c}{ Q. M. } \\
\hline Velocidade & 3 & $13,5040185(0,35994) * *$ \\
Resíduo & 12 & 11,4767 \\
\hline
\end{tabular}

**Não significativo ao nível de $5 \%$ de probabilidade. 
Tabela 28. Resumo da análise da variância para a variável Índice de Ponteiros.

\begin{tabular}{ccl} 
C. V. & G. L. & \multicolumn{1}{c}{ Q. M. } \\
\hline Velocidade & 3 & $9,70324(0,2345)^{* *}$ \\
Resíduo & 12 & 5,96203 \\
\hline
\end{tabular}

**Não significativo ao nível de $5 \%$ de probabilidade.

Tabela 29. Resumo da análise da variância para a variável Índice de Folhas.

\begin{tabular}{ccl}
\hline C. V. & G. L. & \multicolumn{1}{c}{ Q. M. } \\
\hline Velocidade & 3 & $12,3586(0,00176)^{*}$ \\
Resíduo & 12 & 1,2444493 \\
\hline
\end{tabular}

*Significativo ao nível de $5 \%$ de probabilidade

Tabela 30. Teste Tukey para a variável Índice de Folhas.

\begin{tabular}{cccc}
\hline Velocidade & Médias (\%) & $5 \%$ & $1 \%$ \\
\hline V3 & 1,85 & $\mathrm{a}$ & $\mathrm{A}$ \\
V4 & 1,16 & $\mathrm{a}$ & $\mathrm{AB}$ \\
V2 & 1,12 & $\mathrm{a}$ & $\mathrm{AB}$ \\
V1 & 0,38 & $\mathrm{~b}$ & $\mathrm{~B}$ \\
\hline
\end{tabular}

Médias seguidas por letras distintas diferem entre si ao nível de significância indicado.

Tabela 31. Resumo da análise da variância para a variável Índice de Palhas.

\begin{tabular}{ccc}
\hline C. V. & G. L. & \multicolumn{1}{c}{ Q. M. } \\
\hline Velocidade & 3 & $2.1989(0,58388)^{* *}$ \\
Resíduo & 12 & 3,23619 \\
\hline
\end{tabular}

**Não significativo ao nível de $5 \%$ de probabilidade.

Tabela 32 Resumo da análise da variância para a variável Índice de Raízes.

\begin{tabular}{ccl}
\hline C.V. & G.L. & \multicolumn{1}{c}{ Q.M } \\
\hline Velocidade & 3 & $40,429(0,043)^{*}$ \\
Residuos & 12 & 13,1996 \\
\hline
\end{tabular}

*Significativo ao nível de $5 \%$ de probabilidade. 
Tabela 33. Teste Tukey para a variável Índice de Raízes.

\begin{tabular}{cccc}
\hline Velocidade & Médias (\%) & $5 \%$ & $1 \%$ \\
\hline V2 & 2,37 & $\mathrm{a}$ & $\mathrm{A}$ \\
V4 & 0,73 & $\mathrm{~b}$ & $\mathrm{~A}$ \\
V3 & 0,15 & $\mathrm{~b}$ & $\mathrm{~A}$ \\
V1 & 0,12 & $\mathrm{~b}$ & $\mathrm{~A}$ \\
\hline
\end{tabular}

Médias seguidas por letras distintas diferem entre si ao nível de significância indicado.

Tabela 34. Resumo da análise da variância para a variável Índice de Matéria Estranha Vegetal.

\begin{tabular}{ccl}
\hline C. V. & G. L. & \multicolumn{1}{c}{ Q. M. } \\
\hline Velocidade & 3 & $0,5470(0,2706)^{* *}$ \\
Resíduo & 12 & 6,4758 \\
\hline
\end{tabular}

**Não significativo ao nível de $5 \%$ de probabilidade.

Tabela 35. Resumo da análise da variância para a variável, Índice de Matéria Estranha Mineral.

\begin{tabular}{ccl}
\hline C. V. & G. L. & \multicolumn{1}{c}{ Q.M. } \\
\hline Velocidade & 3 & $12,0277(0,00732)^{*}$ \\
Resíduo & 12 & 1,8317403 \\
\hline
\end{tabular}

* Significativo ao nível de $5 \%$ de probabilidade.

Tabela 36 teste de Tukey para a variável Índice de Matéria Estranha Mineral.

\begin{tabular}{cccc}
\hline Velocidade & Médias $(\%)$ & $5 \%$ & $1 \%$ \\
\hline V4 & 0,66 & $\mathrm{a}$ & $\mathrm{A}$ \\
V2 & 0,45 & $\mathrm{ab}$ & $\mathrm{A}$ \\
V1 & 0,07 & $\mathrm{~b}$ & $\mathrm{~A}$ \\
V3 & 0,08 & $\mathrm{~b}$ & $\mathrm{~A}$
\end{tabular}

Médias seguidas por letras distintas diferem entre si ao nível de significância indicado. 
Tabela 37 Resumo da análise da variância para a variável Índice de Matéria Estranha Total.

C. V.

Velocidade

Resíduo
G. L.

3

12 Q. M.

$11,301245(0,22585)^{* *}$

6,774066

**Não significativo ao nível de $5 \%$ de probabilidade.

Tabela 39. Resumo da análise da variância para as variáveis da qualidade tecnológica da matéria prima.

\begin{tabular}{|c|c|c|c|c|}
\hline & & Causa da variação & & \\
\hline Velocidade G.L. & Resíduos G. L. & Q.M & (V) & $\mathrm{F}$ \\
\hline 3 & 12 & Brix $(\%)$ caldo & $(0,432)(0,211)$ & $0,160^{* *}$ \\
\hline 3 & 12 & Pol $(\%)$ caldo & $(0,937)(0,419)$ & $0,548 * *$ \\
\hline 3 & 12 & Pureza $(\%)$ caldo & $(1,263)(3,462)$ & $0,781^{* *}$ \\
\hline 3 & 12 & Fibra $(\%)$ cana & $(0,914)(0,462)$ & $0,170^{* *}$ \\
\hline 3 & 12 & Pol(\%) cana & $(0,244)(0,239)$ & $0,419^{* *}$ \\
\hline 3 & 12 & Terra(kgf) & $(1,291)(0,895)$ & $0,279 * *$ \\
\hline
\end{tabular}

** Não significativo ao nível de $5 \%$ de probabilidade.

Tabela 40. Fluxo de caixa da colhedora na velocidadeV1, Eficiência de Campo estimada para 45\%, constituindo-se na Capacidade Operacional de 7,33 $\left(\mathrm{t} . \mathrm{h}^{-1}\right)$.

\begin{tabular}{lrrrrrrrr}
\multicolumn{1}{c}{ Ano } & \multicolumn{1}{c}{ 1 } & \multicolumn{1}{c}{ 2 } & \multicolumn{1}{c}{ 3 } & \multicolumn{1}{c}{ 4 } & \multicolumn{1}{c}{5} & \multicolumn{1}{c}{6} & \multicolumn{1}{c}{ Total } & \multicolumn{1}{c}{$(\%)$} \\
\hline Depreciação & 40050 & 40050 & 40050 & 40050 & 40050 & 40050 & 240300 & 29,980 \\
Juros & 32048 & 27234 & 22428 & 17622 & 12816 & 8010 & 120158 & 14,991 \\
Seguro & 2776,8 & 2360,28 & 1943,76 & 1527,24 & 1110,72 & 694 & 10412,8 & 1,299 \\
Aloj.+ Adm. & 867,75 & 867,75 & 867,75 & 867,75 & 867,75 & 867,75 & 5206,5 & 0,650 \\
Combustivel & 13482 & 13482 & 13482 & 13482 & 13482 & 13482 & 80892 & 10,092 \\
Óleo hid. & 943,371 & 943,371 & 943,371 & 943,371 & 943,371 & 943,371 & 5660,226 & 0,706 \\
Óleo lub. & 465,9 & 465,9 & 465,9 & 465,9 & 465,9 & 465,9 & 2795,4 & 0,349 \\
Peças rep.+ filt. & 34685,41 & 35121,31 & 35666,86 & 48570,8 & 36172,13 & 36464,87 & 226681,4 & 28,281 \\
Sal.Mec. & 5044 & 5044 & 5044 & 5044 & 5044 & 5044 & 30264 & 3,776 \\
Sal Oper. & 7111 & 7111 & 7111 & 7111 & 7111 & 7111 & 42666 & 5,323 \\
Comb.M.A.P. & 6083,98 & 6083,98 & 6083,98 & 6083,98 & 6083,98 & 6083,98 & 36503,88 & 4,554 \\
Total & & & & & & & 801540,2 & 100 \\
\hline
\end{tabular}


Tabela 41. Fluxo de caixa da colhedora na velocidadeV1, Eficiência de Campo estimada para 55\%, constituindo-se na Capacidade Operacional de $8,95\left(\mathrm{t} \cdot \mathrm{h}^{-1}\right)$.

\begin{tabular}{lrrrrrrrr}
\hline \multicolumn{1}{c}{ Ano } & \multicolumn{1}{c}{ 1 } & \multicolumn{1}{c}{ 2 } & \multicolumn{1}{c}{ 3 } & \multicolumn{1}{c}{4} & \multicolumn{1}{c}{5} & \multicolumn{1}{c}{6} & \multicolumn{1}{c}{ Total } & \multicolumn{1}{c}{$(\%)$} \\
\hline Depreciação & 40050 & 40050 & 40050 & 40050 & 40050 & 40050 & 240300 & 29,281 \\
Juros & 32048 & 27234 & 22428 & 17622 & 12816 & 8010 & 120158 & 14,642 \\
Seguro & 2776,8 & 2360,28 & 1943,76 & 1527,24 & 1110,72 & 694 & 10412,8 & 1,269 \\
Aloj.+ Adm. & 867,75 & 867,75 & 867,75 & 867,75 & 867,75 & 867,75 & 5206,5 & 0,634 \\
Combustivel & 16461 & 16461 & 16461 & 16461 & 16461 & 16461 & 98766 & 12,035 \\
Óleo hid. & 1151,86 & 1151,86 & 1151,86 & 1151,86 & 1151,86 & 1151,86 & 6911,16 & 0,842 \\
Óleo lub. & 465,9 & 465,9 & 465,9 & 465,9 & 465,9 & 465,9 & 2795,4 & 0,341 \\
Peças rep.+ filt. & 34685,41 & 35121,31 & 35666,86 & 48570,8 & 36172,13 & 36464,87 & 226681,4 & 27,622 \\
Sal.Mec. & 5044 & 5044 & 5044 & 5044 & 5044 & 5044 & 30264 & 3,688 \\
Sal Oper. & 7111 & 7111 & 7111 & 7111 & 7111 & 7111 & 42666 & 5,199 \\
Comb.M.A.P. & 6083,98 & 6083,98 & 6083,98 & 6083,98 & 6083,98 & 6083,98 & 36503,88 & 4,448 \\
Total & & & & & & & 820665,1 & 100 \\
\hline
\end{tabular}

Tabela 42. Fluxo de caixa da colhedora na velocidadeV1, Eficiência de Campo estimada para $65 \%$, constituindo-se na Capacidade Operacional de $10,68\left(\mathrm{t} \cdot \mathrm{h}^{\mathrm{H}}\right)$.

\begin{tabular}{lrrrrrrrr}
\multicolumn{1}{c}{ Ano } & \multicolumn{1}{c}{ l } & \multicolumn{1}{c}{ 2 } & \multicolumn{1}{c}{3} & \multicolumn{1}{c}{4} & \multicolumn{1}{c}{5} & \multicolumn{1}{c}{6} & \multicolumn{1}{c}{ Total } & \multicolumn{1}{c}{$(\%)$} \\
\hline Depreciação & 40050 & 40050 & 40050 & 40050 & 40050 & 40050 & 240300 & 28,609 \\
Juros & 32048 & 27234 & 22428 & 17622 & 12816 & 8010 & 120158 & 14,305 \\
Seguro & 2776,8 & 2360,28 & 1943,76 & 1527,24 & 1110,72 & 694 & 10412,8 & 1,240 \\
Aloj.+ Adm. & 867,75 & 867,75 & 867,75 & 867,75 & 867,75 & 867,75 & 5206,5 & 0,620 \\
Combustível & 19467 & 19467 & 19467 & 19467 & 19467 & 19467 & 116802 & 13,906 \\
Oleo hid. & 1361,64 & 1361,64 & 1361,64 & 1361,64 & 1361,64 & 1361,64 & 8169,84 & 0,973 \\
Oleo lub. & 465,9 & 465,9 & 465,9 & 465,9 & 465,9 & 465,9 & 2795,4 & 0,333 \\
Peças rep.+ filt. & 34685,41 & 35121,31 & 35666,86 & 48570,8 & 36172,13 & 36464,87 & 226681,4 & 26,987 \\
Sal.Mec. & 5044 & 5044 & 5044 & 5044 & 5044 & 5044 & 30264 & 3,603 \\
Sal Oper. & 7111 & 7111 & 7111 & 7111 & 7111 & 7111 & 42666 & 5,080 \\
Comb.M.A.P. & 6083,98 & 6083,98 & 6083,98 & 6083,98 & 6083,98 & 6083,98 & 36503,88 & 4,346 \\
Total & & & & & & & 839959,8 & 100 \\
\hline
\end{tabular}

Tabela 43. Fluxo de caixa da colhedora na velocidadeV1, Eficiência de Campo estimada para $75 \%$, constituindo-se na Capacidade Operacional de $12,21\left(\mathrm{t}^{\mathrm{h}} \mathrm{h}^{-1}\right)$.

\begin{tabular}{lrrrrrrrr}
\multicolumn{1}{c}{ Ano } & \multicolumn{1}{c}{ 1 } & \multicolumn{1}{c}{ 2 } & \multicolumn{1}{c}{3} & \multicolumn{1}{c}{4} & \multicolumn{1}{c}{5} & \multicolumn{1}{c}{ Total } & \multicolumn{1}{c}{$(\%)$} \\
\hline Depreciação & 40050 & 40050 & 40050 & 40050 & 40050 & 40050 & 240300 & 27,969 \\
Juros & 32048 & 27234 & 22428 & 17622 & 12816 & 8010 & 120158 & 13,985 \\
Seguro & 2776,8 & 2360,28 & 1943,76 & 1527,24 & 1110,72 & 694 & 10412,8 & 1,212 \\
Aloj.+ Adm. & 867,75 & 867,75 & 867,75 & 867,75 & 867,75 & 867,75 & 5206,5 & 0,606 \\
Combustível & 22459 & 22459 & 22459 & 22459 & 22459 & 22459 & 134754 & 15,684 \\
Óleo hid. & 1571,42 & 1571,42 & 1571,42 & 1571,42 & 1571,42 & 1571,42 & 9428,52 & 1,097 \\
Óleo lub. & 465,9 & 465,9 & 465,9 & 465,9 & 465,9 & 465,9 & 2795,4 & 0,325 \\
Peças rep.+ filt. & 34685,41 & 35121,31 & 35666,86 & 48570,8 & 36172,13 & 36464,87 & 226681,4 & 26,384 \\
Sal.Mec. & 5044 & 5044 & 5044 & 5044 & 5044 & 5044 & 30264 & 3,522 \\
Sal Oper. & 7111 & 7111 & 7111 & 7111 & 7111 & 7111 & 42666 & 4,966 \\
Comb.M.A.P. & 6083,98 & 6083,98 & 6083,98 & 6083,98 & 6083,98 & 6083,98 & 36503,88 & 4,249 \\
Total & & & & & & & 859170,5 & 100 \\
\hline
\end{tabular}


Tabela 44. Fluxo de caixa da colhedora na velocidadeV2, Eficiência de Campo estimada para 45\%, constituindo-se na Capacidade Operacional de 16,33 (t. $\left.\mathrm{h}^{-1}\right)$.

\begin{tabular}{lrrrrrrrr}
\multicolumn{1}{c}{ Ano } & \multicolumn{1}{c}{1} & \multicolumn{1}{c}{ 2 } & \multicolumn{1}{c}{3} & \multicolumn{1}{c}{4} & \multicolumn{1}{c}{5} & \multicolumn{1}{c}{6} & \multicolumn{1}{c}{ Total } & \multicolumn{1}{c}{$(\%)$} \\
\hline Depreciação & 40050 & 40050 & 40050 & 40050 & 40050 & 40050 & 240300 & 29,860 \\
Juros & 32048 & 27234 & 22428 & 17622 & 12816 & 8010 & 120158 & 14,931 \\
Seguro & 2776,8 & 2360,28 & 1943,76 & 1527,24 & 1110,72 & 694 & 10412,8 & 1,294 \\
Aloj.+ Adm. & 867,75 & 867,75 & 867,75 & 867,75 & 867,75 & 867,75 & 5206,5 & 0,647 \\
Combustível & 12858 & 12858 & 12858 & 12858 & 12858 & 12858 & 77148 & 9,587 \\
Óleo hid. & 2101,67 & 2101,67 & 2101,67 & 2101,67 & 2101,67 & 2101,67 & 12610,02 & 1,567 \\
Óleo lub. & 465,9 & 465,9 & 465,9 & 465,9 & 465,9 & 465,9 & 2795,4 & 0,347 \\
Peças rep.+ filt. & 34685,41 & 35121,31 & 35666,86 & 48570,8 & 36172,13 & 36464,87 & 226681,4 & 28,168 \\
Sal.Mec. & 5044 & 5044 & 5044 & 5044 & 5044 & 5044 & 30264 & 3,761 \\
Sal Oper. & 7111 & 7111 & 7111 & 7111 & 7111 & 7111 & 42666 & 5,302 \\
Comb.M.A.P. & 6083,98 & 6083,98 & 6083,98 & 6083,98 & 6083,98 & 6083,98 & 36503,88 & 4,536 \\
Total & & & & & & & 804746 & 100 \\
\hline
\end{tabular}

Tabela 45. Fluxo de caixa da colhedora na velocidadeV2, Eficiência de Campo estimada para 55\%, constituindo-se na Capacidade Operacional de $19,95\left(\mathrm{t} . \mathrm{h}^{-1}\right)$.

\begin{tabular}{lrrrrrrrr}
\multicolumn{1}{c}{ Ano } & \multicolumn{1}{c}{ 1 } & \multicolumn{1}{c}{ 2 } & \multicolumn{1}{c}{3} & \multicolumn{1}{c}{4} & \multicolumn{1}{c}{5} & \multicolumn{1}{c}{6} & \multicolumn{1}{c}{ Total } & \multicolumn{1}{c}{$(\%)$} \\
\hline Depreciação & 40050 & 40050 & 40050 & 40050 & 40050 & 40050 & 240300 & 29,141 \\
Juros & 32048 & 27234 & 22428 & 17622 & 12816 & 8010 & 120158 & 14,571 \\
Seguro & 2776,8 & 2360,28 & 1943,76 & 1527,24 & 1110,72 & 694 & 10412,8 & 1,263 \\
Aloj.+ Adm. & 867,75 & 867,75 & 867,75 & 867,75 & 867,75 & 867,75 & 5206,5 & 0,631 \\
Combustível & 15705 & 15705 & 15705 & 15705 & 15705 & 15705 & 94230 & 11,427 \\
Óleo hid. & 2567,56 & 2567,56 & 2567,56 & 2567,56 & 2567,56 & 2567,56 & 15405,36 & 1,868 \\
Óleo lub. & 465,9 & 465,9 & 465,9 & 465,9 & 465,9 & 465,9 & 2795,4 & 0,339 \\
Peças rep.+ filt. & 34685,41 & 35121,31 & 35666,86 & 48570,8 & 36172,13 & 36464,87 & 226681,4 & 27,489 \\
Sal.Mec. & 5044 & 5044 & 5044 & 5044 & 5044 & 5044 & 30264 & 3,670 \\
Sal Oper. & 7111 & 7111 & 7111 & 7111 & 7111 & 7111 & 42666 & 5,174 \\
Comb.M.A.P. & 6083,98 & 6083,98 & 6083,98 & 6083,98 & 6083,98 & 6083,98 & 36503,88 & 4,427 \\
Total & & & & & & & 824623,3 & 100 \\
\hline
\end{tabular}

Tabela 46 Fluxo de caixa da colhedora na velocidadeV2, Eficiência de Campo estimada para $65 \%$, constituindo-se na Capacidade Operacional de 23,58 (t. $\left.{ }^{-1}\right)$.

\begin{tabular}{lrrrrrrrr}
\multicolumn{1}{c}{ Ano } & \multicolumn{1}{c}{ l } & \multicolumn{1}{c}{ 2 } & \multicolumn{1}{c}{3} & \multicolumn{1}{c}{4} & \multicolumn{1}{c}{5} & \multicolumn{1}{c}{6} & \multicolumn{1}{c}{ Total } & $(\%)$ \\
\hline Depreciação & 40050 & 40050 & 40050 & 40050 & 40050 & 40050 & 240300 & 28,452 \\
Juros & 32048 & 27234 & 22428 & 17622 & 12816 & 8010 & 120158 & 14,227 \\
Seguro & 2776,8 & 2360,28 & 1943,76 & 1527,24 & 1110,72 & 694 & 10412,8 & 1,233 \\
Aloj.+ Adm. & 867,75 & 867,75 & 867,75 & 867,75 & 867,75 & 867,75 & 5206,5 & 0,616 \\
Combustível & 18566 & 18566 & 18566 & 18566 & 18566 & 18566 & 111396 & 13,189 \\
Óleo hid. & 3034,64 & 3034,64 & 3034,64 & 3034,64 & 3034,64 & 3034,64 & 18207,84 & 2,156 \\
Óleo lub. & 465,9 & 465,9 & 465,9 & 465,9 & 465,9 & 465,9 & 2795,4 & 0,331 \\
Peças rep.+ filt. & 34685,41 & 35121,31 & 35666,86 & 48570,8 & 36172,13 & 36464,87 & 226681,4 & 26,839 \\
Sal.Mec. & 5044 & 5044 & 5044 & 5044 & 5044 & 5044 & 30264 & 3,583 \\
Sal Oper. & 7111 & 7111 & 7111 & 7111 & 7111 & 7111 & 42666 & 5,052 \\
Comb.M.A.P. & 6083,98 & 6083,98 & 6083,98 & 6083,98 & 6083,98 & 6083,98 & 36503,88 & 4,322 \\
Total & & & & & & & 844591,8 & 100 \\
\hline
\end{tabular}


Tabela 47. Fluxo de caixa da colhedora na velocidadeV2, Eficiência de Campo estimada para 75\%, constituindo-se na Capacidade Operacional de 27,21 (t.h $\left.\mathrm{h}^{-1}\right)$.

\begin{tabular}{lrrrrrrrr}
\multicolumn{1}{c}{ Ano } & \multicolumn{1}{c}{ 1 } & \multicolumn{1}{c}{ 2 } & \multicolumn{1}{c}{3} & \multicolumn{1}{c}{4} & \multicolumn{1}{c}{5} & \multicolumn{1}{c}{6} & \multicolumn{1}{c}{ Total } & \multicolumn{1}{c}{$(\%)$} \\
\hline Depreciação & 40050 & 40050 & 40050 & 40050 & 40050 & 40050 & 240300 & 27,795 \\
Juros & 32048 & 27234 & 22428 & 17622 & 12816 & 8010 & 120158 & 13,898 \\
Seguro & 2776,8 & 2360,28 & 1943,76 & 1527,24 & 1110,72 & 694 & 10412,8 & 1,204 \\
Aloj.+ Adm. & 867,75 & 867,75 & 867,75 & 867,75 & 867,75 & 867,75 & 5206,5 & 0,602 \\
Combustível & 21426 & 21426 & 21426 & 21426 & 21426 & 21426 & 128556 & 14,870 \\
Óleo hid. & 3501,92 & 3501,92 & 3501,92 & 3501,92 & 3501,92 & 3501,92 & 21011,52 & 2,430 \\
Óleo lub. & 465,9 & 465,9 & 465,9 & 465,9 & 465,9 & 465,9 & 2795,4 & 0,323 \\
Peças rep.+ filt. & 34685,41 & 35121,31 & 35666,86 & 48570,8 & 36172,13 & 36464,87 & 226681,4 & 26,219 \\
Sal.Mec. & 5044 & 5044 & 5044 & 5044 & 5044 & 5044 & 30264 & 3,501 \\
Sal Oper. & 7111 & 7111 & 7111 & 7111 & 7111 & 7111 & 42666 & 4,935 \\
Comb.M.A.P. & 6083,98 & 6083,98 & 6083,98 & 6083,98 & 6083,98 & 6083,98 & 36503,88 & 4,222 \\
Total & & & & & & & 864555,5 & 100 \\
\hline
\end{tabular}

Tabela 48. Fluxo de caixa da colhedora na velocidadeV3, Eficiência de Campo estimada para 45\%, constituindo-se na Capacidade Operacional de 39,45 (t.h $\left.\mathrm{h}^{-1}\right)$.

\begin{tabular}{lrrrrrrrr}
\multicolumn{1}{c}{ Ano } & \multicolumn{1}{c}{ 1 } & \multicolumn{1}{c}{ 2 } & \multicolumn{1}{c}{3} & \multicolumn{1}{c}{4} & \multicolumn{1}{c}{5} & \multicolumn{1}{c}{6} & \multicolumn{1}{c}{ Total } & \multicolumn{1}{c}{$(\%)$} \\
\hline Depreciação & 40050 & 40050 & 40050 & 40050 & 40050 & 40050 & 240300 & 28,326 \\
Juros & 32048 & 27234 & 22428 & 17622 & 12816 & 8010 & 120158 & 14,164 \\
Seguro & 2776,8 & 2360,28 & 1943,76 & 1527,24 & 1110,72 & 694 & 10412,8 & 1,227 \\
Aloj.+ Adm. & 867,75 & 867,75 & 867,75 & 867,75 & 867,75 & 867,75 & 5206,5 & 0,614 \\
Combustível & 17148 & 17148 & 17148 & 17148 & 17148 & 17148 & 102888 & 12,128 \\
Óleo hid. & 5077,21 & 5077,21 & 5077,21 & 5077,21 & 5077,21 & 5077,21 & 30463,26 & 3,591 \\
Óleo lub. & 465,9 & 465,9 & 465,9 & 465,9 & 465,9 & 465,9 & 2795,4 & 0,330 \\
Peças rep.+ filt. & 34685,41 & 35121,31 & 35666,86 & 48570,8 & 36172,13 & 36464,87 & 226681,4 & 26,721 \\
Sal.Mec. & 5044 & 5044 & 5044 & 5044 & 5044 & 5044 & 30264 & 3,567 \\
Sal Oper. & 7111 & 7111 & 7111 & 7111 & 7111 & 7111 & 42666 & 5,029 \\
Comb.M.A.P. & 6083,98 & 6083,98 & 6083,98 & 6083,98 & 6083,98 & 6083,98 & 36503,88 & 4,303 \\
Total & & & & & & & 848339,2 & 100 \\
\hline
\end{tabular}

Tabela 49. Fluxo de caixa da colhedora na velocidadeV3, Eficiência de Campo estimada para 55\%, constituindo-se na Capacidade Operacional de 48,21 (t.h ${ }^{-1}$ ).

\begin{tabular}{lrrrrrrrr}
\multicolumn{1}{c}{ Ano } & \multicolumn{1}{c}{ 1 } & \multicolumn{1}{c}{ 2 } & \multicolumn{1}{c}{3} & \multicolumn{1}{c}{4} & \multicolumn{1}{c}{5} & \multicolumn{1}{c}{6} & \multicolumn{1}{c}{ Total } & \multicolumn{1}{c}{ (\%) } \\
\hline Depreciação & 40050 & 40050 & 40050 & 40050 & 40050 & 40050 & 240300 & 27,363 \\
Juros & 32048 & 27234 & 22428 & 17622 & 12816 & 8010 & 120158 & 13,682 \\
Seguro & 2776,8 & 2360,28 & 1943,76 & 1527,24 & 1110,72 & 694 & 10412,8 & 1,186 \\
Aloj.+ Adm. & 867,75 & 867,75 & 867,75 & 867,75 & 867,75 & 867,75 & 5206,5 & 0,593 \\
Combustível & 20998 & 20998 & 20998 & 20998 & 20998 & 20998 & 125988 & 14,346 \\
Óleo hid. & 6204,62 & 6204,62 & 6204,62 & 6204,62 & 6204,62 & 6204,62 & 37227,72 & 4,239 \\
Óleo lub. & 465,9 & 465,9 & 465,9 & 465,9 & 465,9 & 465,9 & 2795,4 & 0,318 \\
Peças rep.+ filt. & 34685,41 & 35121,31 & 35666,86 & 48570,8 & 36172,13 & 36464,87 & 226681,4 & 25,812 \\
Sal.Mec. & 5044 & 5044 & 5044 & 5044 & 5044 & 5044 & 30264 & 3,446 \\
Sal Oper. & 7111 & 7111 & 7111 & 7111 & 7111 & 7111 & 42666 & 4,858 \\
Comb.M.A.P. & 6083,98 & 6083,98 & 6083,98 & 6083,98 & 6083,98 & 6083,98 & 36503,88 & 4,157 \\
Total & & & & & & & 878203,7 & 100 \\
\hline
\end{tabular}


Tabela 50. Fluxo de caixa da colhedora na velocidadeV3, Eficiência de Campo estimada para 65\%, constituindo-se na Capacidade Operacional de 56,98 (t. $\left.\mathrm{h}^{-1}\right)$.

\begin{tabular}{lrrrrrrrr}
\multicolumn{1}{c}{ Ano } & \multicolumn{1}{c}{ 1 } & \multicolumn{1}{c}{ 2 } & \multicolumn{1}{c}{3} & \multicolumn{1}{c}{4} & \multicolumn{1}{c}{5} & \multicolumn{1}{c}{6} & \multicolumn{1}{c}{ Total } & \multicolumn{1}{c}{$\%)$} \\
\hline Depreciação & 40050 & 40050 & 40050 & 40050 & 40050 & 40050 & 240300 & 26,477 \\
Juros & 32048 & 27234 & 22428 & 17622 & 12816 & 8010 & 120158 & 13,239 \\
Seguro & 2776,8 & 2360,28 & 1943,76 & 1527,24 & 1110,72 & 694 & 10412,8 & 1,147 \\
Aloj.+ Adm. & 867,75 & 867,75 & 867,75 & 867,75 & 867,75 & 867,75 & 5206,5 & 0,574 \\
Combustível & 24765 & 24765 & 24765 & 24765 & 24765 & 24765 & 148590 & 16,372 \\
Óleo hid. & 7333,32 & 7333,32 & 7333,32 & 7333,32 & 7333,32 & 7333,32 & 43999,92 & 4,848 \\
Óleo lub. & 465,9 & 465,9 & 465,9 & 465,9 & 465,9 & 465,9 & 2795,4 & 0,308 \\
Peças rep.+ filt. & 34685,41 & 35121,31 & 35666,86 & 48570,8 & 36172,13 & 36464,87 & 226681,4 & 24,977 \\
Sal.Mec. & 5044 & 5044 & 5044 & 5044 & 5044 & 5044 & 30264 & 3,335 \\
Sal Oper. & 7111 & 7111 & 7111 & 7111 & 7111 & 7111 & 42666 & 4,701 \\
Comb.M.A.P. & 6083,98 & 6083,98 & 6083,98 & 6083,98 & 6083,98 & 6083,98 & 36503,88 & 4,022 \\
Total & & & & & & & 907577,9 & 100 \\
\hline
\end{tabular}

Tabela 51. Fluxo de caixa da colhedora na velocidadeV3, Eficiência de Campo estimada para $75 \%$, constituindo-se na Capacidade Operacional de $65,75\left(\mathrm{t}^{-1} \mathrm{~h}^{-1}\right)$.

\begin{tabular}{lrrrrrrrr}
\multicolumn{1}{c}{ Ano } & \multicolumn{1}{c}{ 1 } & \multicolumn{1}{c}{ 2 } & \multicolumn{1}{c}{3} & \multicolumn{1}{c}{4} & \multicolumn{1}{c}{5} & \multicolumn{1}{c}{6} & \multicolumn{1}{c}{ Total } & \multicolumn{1}{c}{$(\%)$} \\
\hline Depreciação & 40050 & 40050 & 40050 & 40050 & 40050 & 40050 & 240300 & 25,498 \\
Juros & 32048 & 27234 & 22428 & 17622 & 12816 & 8010 & 120158 & 12,750 \\
Seguro & 2776,8 & 2360,28 & 1943,76 & 1527,24 & 1110,72 & 694 & 10412,8 & 1,105 \\
Aloj.+ Adm. & 867,75 & 867,75 & 867,75 & 867,75 & 867,75 & 867,75 & 5206,5 & 0,552 \\
Combustível & 29446 & 29446 & 29446 & 29446 & 29446 & 29446 & 176676 & 18,747 \\
Óleo hid. & 8462,02 & 8462,02 & 8462,02 & 8462,02 & 8462,02 & 8462,02 & 50772,12 & 5,387 \\
Óleo lub. & 465,9 & 465,9 & 465,9 & 465,9 & 465,9 & 465,9 & 2795,4 & 0,297 \\
Peças rep.+ filt. & 34685,41 & 35121,31 & 35666,86 & 48570,8 & 36172,13 & 36464,87 & 226681,4 & 24,053 \\
Sal.Mec. & 5044 & 5044 & 5044 & 5044 & 5044 & 5044 & 30264 & 3,211 \\
Sal Oper. & 7111 & 7111 & 7111 & 7111 & 7111 & 7111 & 42666 & 4,527 \\
Comb.M.A.P. & 6083,98 & 6083,98 & 6083,98 & 6083,98 & 6083,98 & 6083,98 & 36503,88 & 3,873 \\
Total & & & & & & & 942436,1 & 100 \\
\hline
\end{tabular}

Tabela 52. Fluxo de caixa da colhedora na velocidadeV4, Eficiência de Campo estimada para 45\%, constituindo-se na Capacidade Operacional de 49,58 (t. $\left.\mathrm{h}^{-1}\right)$.

\begin{tabular}{lrrrrrrrr}
\multicolumn{1}{c}{ Ano } & \multicolumn{1}{c}{ 1 } & \multicolumn{1}{c}{ 2 } & \multicolumn{1}{c}{3} & \multicolumn{1}{c}{4} & \multicolumn{1}{c}{5} & \multicolumn{1}{c}{6} & \multicolumn{1}{c}{ Total } & \multicolumn{1}{c}{$(\%)$} \\
\hline Depreciação & 40050 & 40050 & 40050 & 40050 & 40050 & 40050 & 240300 & 27,669 \\
Juros & 32048 & 27234 & 22428 & 17622 & 12816 & 8010 & 120158 & 13,835 \\
Seguro & 2776,8 & 2360,28 & 1943,76 & 1527,24 & 1110,72 & 694 & 10412,8 & 1,199 \\
Aloj.+ Adm. & 867,75 & 867,75 & 867,75 & 867,75 & 867,75 & 867,75 & 5206,5 & 0,599 \\
Combustível & 19202 & 19202 & 19202 & 19202 & 19202 & 19202 & 115212 & 13,266 \\
Óleo hid. & 6380,94 & 6380,94 & 6380,94 & 6380,94 & 6380,94 & 6380,94 & 38285,64 & 4,408 \\
Óleo lub. & 465,9 & 465,9 & 465,9 & 465,9 & 465,9 & 465,9 & 2795,4 & 0,322 \\
Peças rep.+ filt. & 34685,41 & 35121,31 & 35666,86 & 48570,8 & 36172,13 & 36464,87 & 226681,4 & 26,101 \\
Sal.Mec. & 5044 & 5044 & 5044 & 5044 & 5044 & 5044 & 30264 & 3,485 \\
Sal Oper. & 7111 & 7111 & 7111 & 7111 & 7111 & 7111 & 42666 & 4,913 \\
Comb.M.A.P. & 6083,98 & 6083,98 & 6083,98 & 6083,98 & 6083,98 & 6083,98 & 36503,88 & 4,203 \\
Total & & & & & & & 868485,6 & 100 \\
\hline
\end{tabular}


Tabela 53. Fluxo de caixa da colhedora na velocidadeV4, Eficiência de Campo estimada para 55\%, constituindo-se na Capacidade Operacional de 60,59 $\left(\mathrm{t} . \mathrm{h}^{-1}\right)$.

\begin{tabular}{lrrrrrrrr}
\multicolumn{1}{c}{ Ano } & \multicolumn{1}{c}{ 1 } & \multicolumn{1}{c}{ 2 } & \multicolumn{1}{c}{ 3 } & \multicolumn{1}{c}{4} & \multicolumn{1}{c}{5} & \multicolumn{1}{c}{6} & \multicolumn{1}{c}{ Total } & \multicolumn{1}{c}{$(\%)$} \\
\hline Depreciação & 40050 & 40050 & 40050 & 40050 & 40050 & 40050 & 240300 & 26,657 \\
Juros & 32048 & 27234 & 22428 & 17622 & 12816 & 8010 & 120158 & 13,330 \\
Seguro & 2776,8 & 2360,28 & 1943,76 & 1527,24 & 1110,72 & 694 & 10412,8 & 1,155 \\
Aloj.+ Adm. & 867,75 & 867,75 & 867,75 & 867,75 & 867,75 & 867,75 & 5206,5 & 0,578 \\
Combustível & 23278 & 23278 & 23278 & 23278 & 23278 & 23278 & 139668 & 15,494 \\
Óleo hid. & 7797,93 & 7797,93 & 7797,93 & 7797,93 & 7797,93 & 7797,93 & 46787,58 & 5,190 \\
Óleo lub. & 465,9 & 465,9 & 465,9 & 465,9 & 465,9 & 465,9 & 2795,4 & 0,310 \\
Peças rep.+ filt. & 34685,41 & 35121,31 & 35666,86 & 48570,8 & 36172,13 & 36464,87 & 226681,4 & 25,146 \\
Sal.Mec. & 5044 & 5044 & 5044 & 5044 & 5044 & 5044 & 30264 & 3,357 \\
Sal Oper. & 7111 & 7111 & 7111 & 7111 & 7111 & 7111 & 42666 & 4,733 \\
Comb.M.A.P. & 6083,98 & 6083,98 & 6083,98 & 6083,98 & 6083,98 & 6083,98 & 36503,88 & 4,049 \\
Total & & & & & & & 901443,5 & 100 \\
\hline
\end{tabular}

Tabela 54. Fluxo de caixa da colhedora na velocidadeV4, Eficiência de Campo estimada para 65\%, constituindo-se na Capacidade Operacional de 71,61 (t.h $\left.{ }^{-1}\right)$.

\begin{tabular}{|c|c|c|c|c|c|c|c|c|}
\hline Ano & 1 & 2 & 3 & 4 & 5 & 6 & Total & $(\%)$ \\
\hline Depreciação & 40050 & 40050 & 40050 & 40050 & 40050 & 40050 & 240300 & 26,067 \\
\hline Juros & 32048 & 27234 & 22428 & 17622 & 12816 & 8010 & 120158 & 13,034 \\
\hline Seguro & 2776,8 & 2360,28 & 1943,76 & 1527,24 & 1110,72 & 694 & 10412,8 & 1,130 \\
\hline Aloj. + Adm. & 867,75 & 867,75 & 867,75 & 867,75 & 867,75 & 867,75 & 5206,5 & 0,565 \\
\hline Combustível & 25263 & 25263 & 25263 & 25263 & 25263 & 25263 & 151578 & 16,443 \\
\hline Óleo hid. & 9216,2 & 9216,2 & 9216,2 & 9216,2 & 9216,2 & 9216,2 & 55297,2 & 5,998 \\
\hline Óleo lub. & 465,9 & 465,9 & 465,9 & 465,9 & 465,9 & 465,9 & 2795,4 & 0,303 \\
\hline Peças rep. + filt. & 34685,41 & 35121,31 & 35666,86 & 48570,8 & 36172,13 & 36464,87 & 226681,4 & 24,589 \\
\hline Sal.Mec. & 5044 & 5044 & 5044 & 5044 & 5044 & 5044 & 30264 & 3,283 \\
\hline Sal Oper. & 7111 & 7111 & 7111 & 7111 & 7111 & 7111 & 42666 & 4,628 \\
\hline Comb.M.A.P. & 6083,98 & 6083,98 & 6083,98 & 6083,98 & 6083,98 & 6083,98 & 36503,88 & 3,960 \\
\hline Total & & & & & & & 921863,2 & 100 \\
\hline
\end{tabular}

Tabela 55. Fluxo de caixa da colhedora na velocidadeV4, Eficiência de Campo estimada para 75\%, constituindo-se na Capacidade Operacional de 82,63 (t.h $\mathrm{h}^{-1}$ ).

\begin{tabular}{lrrrrrrrr}
\multicolumn{1}{c}{ Ano } & \multicolumn{1}{r}{} & \multicolumn{1}{c}{ 2 } & \multicolumn{1}{c}{ 3 } & \multicolumn{1}{c}{4} & \multicolumn{1}{c}{5} & \multicolumn{1}{c}{6} & \multicolumn{1}{c}{ Total } & $(\%)$ \\
\hline Depreciação & 40050 & 40050 & 40050 & 40050 & 40050 & 40050 & 240300 & 24,785 \\
Juros & 32048 & 27234 & 22428 & 17622 & 12816 & 8010 & 120158 & 12,393 \\
Seguro & 2776,8 & 2360,28 & 1943,76 & 1527,24 & 1110,72 & 694 & 10412,8 & 1,074 \\
Aloj.+ Adm. & 867,75 & 867,75 & 867,75 & 867,75 & 867,75 & 867,75 & 5206,5 & 0,537 \\
Combustível & 31789 & 31789 & 31789 & 31789 & 31789 & 31789 & 190734 & 19,673 \\
Óleo hid. & 10634,48 & 10634,48 & 10634,48 & 10634,48 & 10634,48 & 10634,48 & 63806,88 & 6,581 \\
Óleo lub. & 465,9 & 465,9 & 465,9 & 465,9 & 465,9 & 465,9 & 2795,4 & 0,288 \\
Peças rep.+ filt. & 34685,41 & 35121,31 & 35666,86 & 48570,8 & 36172,13 & 36464,87 & 226681,4 & 23,381 \\
Sal.Mec. & 5044 & 5044 & 5044 & 5044 & 5044 & 5044 & 30264 & 3,122 \\
Sal Oper. & 7111 & 7111 & 7111 & 7111 & 7111 & 7111 & 42666 & 4,401 \\
Comb.M.A.P. & 6083,98 & 6083,98 & 6083,98 & 6083,98 & 6083,98 & 6083,98 & 36503,88 & 3,765 \\
Total & & & & & & & 969528,8 & 100,000 \\
\hline
\end{tabular}


Tabela 56. Parte final do fluxo de caixa, com o resumo dos resultados para as 16 capacidades operacionais estimadas, considerando-se 18.000 horas de vida útil, com seus respectivos custos.

\begin{tabular}{ccccc}
\hline Vel.x Efc. & $($ US $\$)$ & $\left({\left.\text { US } \$ . h^{-1}\right)}^{-1}\right.$ & $\left(\mathrm{t}^{-1}\right)$ & $\left(\right.$ US $\left.^{-1} \mathrm{t}^{-1}\right)$ \\
\hline V145\% & 801540,2 & 44,530 & 7,33 & 6,08 \\
V155\% & 820665,1 & 45,593 & 8,95 & 5,09 \\
V165\% & 839959,8 & 46,664 & 10,68 & 4,37 \\
V175\% & 859170,5 & 47,732 & 12,21 & 3,91 \\
V245\% & 804746 & 44,708 & 16,33 & 2,74 \\
V255\% & 824623,3 & 45,812 & 19,95 & 2,30 \\
V265\% & 844591,8 & 46,922 & 23,58 & 1,99 \\
V275\% & 864555,5 & 48,031 & 27,21 & 1,77 \\
V345\% & 848339,2 & 47,130 & 39,45 & 1,19 \\
V355\% & 878203,7 & 48,789 & 48,21 & 1,01 \\
V365\% & 907577,9 & 50,421 & 56,98 & 0,88 \\
V375\% & 942436,1 & 52,358 & 65,75 & 0,80 \\
V445\% & 868485,6 & 48,249 & 49,58 & 0,97 \\
V455\% & 901443,5 & 50,080 & 60,59 & 0,83 \\
V465\% & 921863,2 & 51,215 & 71,61 & 0,72 \\
V475\% & 969528,8 & 53,863 & 82,63 & 0,65 \\
\hline
\end{tabular}




\section{REFERÊNCIAS BIBLIOGRÁFICAS}

ANDRADE SILVA, G.M. de. Cana crua vs. cana queimada: restrições técnicas e implicações sociais e econômicas, In: SEMANA DA CANA DE AÇÚCAR DE PIRACICABA, 2., Piracicaba, 1997. Anais. Piracicaba: STAB, 1977.55-57p.

ANUÁRIO ESTATÍSTICO DO BRASIL - 1997, Rio de Janeiro, v.57, p.3-51 1997.

ARIZONO, H.; GHELLER, A.C.A.; MASUDA, Y.; HOFFMANN, H.P.; BASSINELLO, A.I.; MATUSUOKA, S. Opções de variedade RB de cana de açúcar. In: Reunião tecnica de variedade de cana de açúcar. IAC. Piracicaba.1993. $1-12 p$.

ARRUDA PINTO, R.S. de; NUNES JR., D. Indicadores de desempenho da agroindústria canavieira, Piracicaba: IDEA, 1998. 68-69p. ( Relatório Técnico)

ARRUDA, J.J.A. História: moderna e contemporânea, São Paulo: Ática, 1996.472p.

BARGER, E.L.; CARLETON, J.B.; LILJEDAHL, J.B.; McKIBBEN, E.G. Tratores e seus motores. São Paulo: Edgard Blucher, 1963. 398 p. 
BASSINELlO, A.I.; FURLANI NETO, V.L.; MACEDO, N.; PARRAZI, C.; CASAGRANDE, J.C. Implicacões agrícolas e industriais da colheita de cana crua. Araras: IAA, PLANALSUCAR, s.d. 55p.

BOHM, G.M. Queima de cana-de-açúcar e saúde humana, STAB. Açúcar, Álcool e Subprodutos, v.16, n.4, p. 40-41, mar/abr. 1998.

BRASIL. Leis, decretos, etc. Decreto $n^{0} 42.056$ de 6 de agosto de 1997. Diário Oficial do Estado de São Paulo, 06 de agosto de 1997. Seção 1, p.3-4. Dispõe sobre o uso, conservação e preservação do solo agrícola para o Estado de São Paulo.

BROUSSARD, K. Appropriate technology and selection of cane harvesting machinery. Sugar Cane, n.3, p.1-3, may/june.1987.

CARVALHO, L.C.C. Perspectivas da cultura de cana-de-açúcar para a década de noventa. Produção de cana-de-açúcar. In: CÂMARA, G.M. de S; OLIVEIRA, E.A.M. Produção de cana-de-açúcar. Piracicaba: FEALQ, 1993. p.1-17.

CENICAÑA. Centro de investigación de la caña de azúcar de Colombia. Cali, v.17, n.4, p.17-28, out/dez. 1995.

CENICAÑA. Centro de investigación de la caña de azúcar de Colombia. Cali, v.18, n.4, p.9-18. out/dez. 1996.

CENICAÑA. Centro de investigación de la caña de azúcar de Colombia. Cali, v.19, n.1, p.7-10. jan/abr.1997a.

CENICAÑA. Centro de investigación de la caña de azúcar de Colombia. Cali, v.19, n.2, p.5-11, abr./jun. 1997b. 
CERQUEIRA LUZ, P.H.; ALOISI, R.R. Influência das colheitas manual e mecânica sobre o rendimento industrial da cana-de-açúcar. Álcool \& Açúcar, v.11, n.58, p.24-27, mai/jun., 1991.

CURY, R. Desempenho operacional de colhedoras na Usina Santa Helena. In: SEMANA DA CANA DE AÇÚCAR DE PIRACICABA, 4., Piracicaba, 1999. Anais. Piracicaba: SACCHARUM, 1999. 48-49p.

DE BEER, A.G. A review of mechanical harvesting and its effect on sugar cane quality. In: INTERNATIONAL SOCIETY OF SUGAR CANE TECHNOLOGISTS, 17., Manila, Feb.1-11.1980. Proceedinos. Philippines, 1980. V.1 p. LVII-LXI

DELGADO, A.A. Os Efeitos da queima dos canaviais, STAB. Açúcar, Álcool e Subprodutos, v.3, n.6, p.42-45, jul/ago., 1985.

DICK, R.G.; GREVIS-JAMES, I.W. The eletronic cane loss monitor. Proceedingd of Australian Society of Sugar Cane Technologists, n.14, 1992 p.150-168.

FERNANDES, A.C.; IRVINE, J.E. Comparação da produtividade da cana-de-açúcar por colheita mecanizada e por corte manual. STAB. Açúcar, Álcool e Subproduto, v.4, n.6, p. 112-126, jul./ago. 1986.

FERNANDES, A.C.; OLIVEIRA, E.R. Determinação e identificação das impurezas em carregamento de cana-de-açúcar. Boletim Téenico Copersucar, n.5, p.5-8, set. 1997.

FORS, A.; ARIS, R. Los distintos componentes de la materia extraña: Como afectan el trabajo de los ingenios. The effects of trash components in factory performance. Sugar Journal, v.12, n.7, p. 25-26, dez. 1997. 
FUELLING, T.G. Sugar cane harvester design. Proceedingd. Australian. Society of. Sugar Cane Technologists, n.5, p.131-137. 1982.

FURLANI NETO, V.L. A colhedora de cana-de-açúcar ( Saccharum spp): avaliação em canaviais com e sem queima prévia. Piracicaba,1995. 110p. Tese (Doutorado)Escola Superior de Agricultura "Luiz de Queiroz", Universidade de São Paulo.

FURLANI NETO, V.L.; FERNANDES, J.; MIALHE, L.G. Avaliação nas cargas de cana-de-açúcar colhidas mecanicamente. Brasil Açucareiro, v.96, n.30, p.25-30. set. 1980.

FURLANI NETO, V.L.; ROLIM, J.C.; RIPOLI, T.C.; MONTEIRO, H.; NOGUEIRA, R.R. Influência de dessecante na colheita mecânica da cana-de-açúcar. Álcool \& Açúcar, v.9, n.51, p.16-19, nov./dez. 1989.

FURLANI NETO, V.L; RIPOLI, T.C.C.; VILLANOVA, N.A.; APPROABATO FILHO, A. Colheita mecanizada de cana crua e queimada: desempenhos e qualidade da matéria-prima. In: CONGRESSO NACIONAL DA SOCIEDADE DOS TÉCNICOS AÇUCAREIROS E ALCOOLEIROS DO BRASIL, 6., Maceió, 1996. Anais. Maceió: STAB, 1996. 533-541p.

GOULART, M.P. Legislação ambiental e queimada de cana, In: SEMANA DA CANA DE AÇÚCAR DE PIRACICABA, 2., Piracicaba, 1997. Anais. Piracicaba: STAB. 1997. 61-64p.

HARRIS, H.; MELLO, R.C. Kinematics, blade shapes and edges for alternative basecutter configurations, Proceedingd. Australian. Society of. Sugar Cane Technologists, n.21, p.185-190. 1999. 
HERRERA, M. de A.; LINARES, S.O. La incidencia del rendimiento ágricola en la eficiencia de limpeza y las perdidas de la ktp-1 cosechando en verde, Cuba Azúcar, v.8, n.2, p. 13-16, jan/mar, 1986.

HURNEY, A.P.; RIDGE, D.R.; DICK, R.G. Evaluation of the efficiency of cane harvesters in removing extraneous matter and in limiting cane losses during the cleaning process. Proceedingd. Australian. Society of. Sugar Cane Technologists, n.17, p.782-799.1984.

IZUMI, H.; UENO, M. Sugar loss due to mechanical harvesting. Sugar Cane, n.1, jan/fev. 1993.

JOHN, L. Máquina que colhe cana pode transformar os canaviais. O Estado de São Paulo. Suplemento Agrícola, São Paulo, 25 nov. 1992. p.12-13

KIEHL, E.J. Manual de edafologia: Relação solo-água-planta. São Paulo: Ceres, 1979. $264 \mathrm{p}$.

KRONKA, P.F.B.; MONTEIRO, J.H. Desempenho operacional de colhedoras na Usina Iturama. In: SEMANA DA CANA DE AÇÚCAR DE PIRACICABA, 4., Piracicaba, 1999. Anais. Piracicaba: SACCHARUM, 1999. 46-48p.

LIMA, L.O.T. Fatores que influenciam na colheita mecânica In: SEMINÁRIO DE COLHEITA MECÂNICA, 1., Ribeirão Preto, 1994.

LIMA, L.O.T.C. Custo de colheita mecanizada, STAB. Açúcar, Álcool e Subprodutos, v.16, n.4, p.29-30, mar/abr. 1998.

MIALHE, L.G. Manual de mecanização agrícola. São Paulo: Agronômica Ceres,1974. $301 \mathrm{p}$. 
MIALHE, L.G.; CARRARO NETO, H.C. Avaliação e análise do desempenho da colhedora de cana-de-açúcar, Olímpia: Usina Cruz Alta de Olímpia S.A,1993.170p. (Relatório Técnico).

MOLINA JR., W.F.; RIPOLI, T.C.; GERALDI, R.N.; AMARAL, J.R. do. Aspectos econômicos e operacionais do enfardamento de resíduos de colheita de cana-deaçúcar para aproveitamento energético STAB. Açúcar, Álcool e subprodutos, v.13, n.5, p.28 - 31, mai/jun., 1995

MORAES, E.E. Avaliação das perdas invisíveis de cana-de-açúcar (Saccharum spp) e impurezas vegetais na colheita mecanizada. Campinas, 1992. Dissertação (Mestrado) Universidade Estadual de Campinas.

MORAES, E.E.; NEVES, J.L.M. Colheita de cana crua: avaliação de perdas invisiveis nos sistemas com colhedora de cana picada. In: SEMINÁRIO COPERSUCAR DE TECNOLOGIA AGRONÔMICA, 7., Piracicaba, 1997. Anais. Piracicaba: COPERSUCAR, 1997. 289-297p.

MORAES, E.E.; NEVES, J.L.M. Colheita de cana crua: perdas no campo e impurezas na carga. In: SEMINÁRIO COPERSUCAR DE TECNOLOGIA AGRONÔMICA, 7.,Piracicaba, 1997. Anais. Piracicaba. COPERSUCAR, 1997. 298-300p.

NORONHA, J.F.; MIALHE, L.G.; DUARTE, L.P. Custos dos sistemas tratorizados na agricultura brasileira. Piracicaba: ESALQ, 1991. 32p.

NORRIS, C.P.; DAVIS, R.J.; QUICK, D.J.; MOHOMMAD, Y. An alternative approach to cane harvester desig: na initial review of the Massey Ferguson 405, Sucar Cane, n.20, p. 10-16. 1998. 
PINTO, L.A.R. Colheita da cana-de-açúcar, Brasil Açucareiro, v.39, n.4, p.38-51, abr. 1977.

PINTO, L.A.R. Desenvolvimento na colheita da cana-de-açúcar, Agricultura de Hoje, v.2, n.20, p.305-355, 1976.

RIDGE, D.R.; DICK, R.G. A new method for testing cane harvester performance. Proceedingd. Australian. Society of. Sugar Cane Technologists, n.9, p.87-92. 1987.

RIDGE, R. Green Cane chopper harvesting in Austrália. Sugar Journal, n.9, p.8-10, nov. 1994.

RIPOLI, T.C. Avaliação de alguns parâmetros de desempenho de três colhedoras de cana-de-açúcar ( Saccharum spp) Piracicaba, 1977. 130p.Dissertação ( Mestrado )Escola Superior de Agricultura “Luiz de Queiroz”, Universidade de São Paulo.

RIPOLI, T.C. Ensaio \& certificação de máquinas para colheita de cana de açúcar. In: MIALHE, L.G. A máquinas agrícolas: ensaios \& certificação, Piracicaba: FEALQ, 1996. p.635-674.

RIPOLI, T.C. Fogo na palha? NOTESALQ, v.1, n.5, p.2-3, nov. 1988.

RIPOLI, T.C.; ALVES BERTO, P.N. Avaliação de desempenho de colhedoras de canade-açúcar na região de Campos, RJ. Brasil Açucareiro, v.2, n.49, p. 20-31, fev./mar. 1981.

RIPOLI, T.C.; MIALHE, L.G. Colheita manual vs. colheita mecanizada da cana- deaçúcar, STAB. Açúcar, Álcool e Subprodutos, v.5, n.3, p. 27- 37, jan/fev. 1987. 
RIPOLI, T.C.; MIALHE, L.G. Custos de colheita da cana-de-açúcar na Estado de São Paulo, na safra 81/82. Álcool \& Açúcar, v.2, n.2, p.18-29, fev/mar.1983.

RIPOLI, T.C.; MIALHE, L.G.; BRITO, J.O. Queima de canavial: o desperdício não mais admissível! Álcool \& Açúcar, v.10, n.54, p.18-23, jul./ago. 1990.

RIPOLI, T.C.; VILLA NOVA, N.A. Colheita mecanizada da cana-de-açúcar: novos desafios, STAB. Açúcar, Álcool e Subprodutos, v.11, n.1, p.28-31, set./out. 1992.

ROMANACH, L.M.; CARON, D. Emprego, trabalho, custo e mecanização da colheita da cana-de-açúcar. STAB. Açúcar, Álcool e Subprodutos. v17, n.5, p.25. mai/jun. 1999.

ROMERO, E.; ZAMORA, F.P.; OLEA, I.; SCANDALIARIS, J.; MARTÍN, L. Evaluación de nuevas cosechadoras integrales. Avance Agroindustrial, v.13, n.52, p.24-28, mar. 1993.

ROZEFF, $N$. The effects of operating velocity on productivity in green and burned sugar cana. Sugar cane, n.1, p.7-19, nov. 1989.

SCANDALIARIS, J.; ROMERO, E.; ZAMORA, F.P. Desempeño de las cosechadoras integrales de nueva generación. Avance Agroindustrial, v.17, n.69, p. 14-18, jul. 1997.

SCHEMBRI, M.; GARSON, C.A. Gathering of green cane by harvesters: a first study Proceedingd. Australian. Society of. Sugar Cane Technologists, n.2, p. 145-151. 1996. 
SHAW, G. R.; BROTHERTON, G. A Green cane harvesting.- A dilemma. Proceedingd of Australian Society of Sugar Cane Technologists, n.14, p. 1 - 7, 1992.

SILVA, M.R.S.; FROES, N.D.T. As cinzas de cana promovem câncer?. STAB. Açúcar, Álcool e Subprodutos v.16, n.4, p.42. mar./abr. 1998.

SMITH, N.J.; McGUIRE, P.M.; MACKSON, J.; HICKLING, R.C. Green cane harvesting: a review with particular reference to the Mulgrave mill area, Sucar Cane, n.5, p.3-8, set/out. 1985.

SOARES, G. de C.; BALBO, L; PINTO, A.R. Colheita mecânica de cana picada. STAB. Açúcar, Álcool e Subprodutos, v.12, n.3, p.18-20, jan./fev. 1994.

SPAROVEK, G. Informações Geográficas para a identificação de áreas com potencialidade para colheita de cana crua. In: SEMANA DA CANA DE AÇÚCAR DE PIRACICABA, 2.,Piracicaba, 1997. Anais Piracicaba: STAB, 58-60p.

STEEL, J.G.; BRADFIELD, R. The significance of size distribution in the clay fraction. In: AMERICAN SOIL SURVEY ASS. Report Bulletin. 1934. p.88-93.

STEWART, R.L.; McCOMISKIE, G. A comparison of green and burnt cane harvesting in the burdekin, Sucar Cane, n.5, p. 27-29, 1988.

STRINI JUNIOR, A. A experiência da Usina Junqueira. In: SEMINÁRIO SOLUÇÕES E NOVIDADES NA MECANIZAÇÃO DA CANA-DE-AÇÚCAR, 1., Ribeirão Preto, 1999. Resumo. Ribeirão Preto: IDEA. 1999. 87-95p. 
STUPIELlO, J.P.; NOVAES, F.V.; DELGADO, A.A.; OLIVEIRA, E.R.; CESAR, M.A.A.; VALSECHI, O. Elementos de tecnologia do acúcar. Piracicaba, ESALQ/Depto. de Tecnologia Rural, 1971. 72p.

TAMBOSCO, N.; TEIXEIRA, J.P.B., GERALDI, L. et. al. Resultados operacionais de colhedoras combinadas. In: CONGRESSO BRASILEIRO DE ENGENHARIA AGRÍCOLA, 7., Pelotas, 1977. Separata. p.10.

VEIGA FILHO, A. de A.; SANTOS, Z.A.P.; VEIGA, J.E.R; OTANI, M.N.; YOSHII. R. J. Estimativa de desempenho na colheita de cana decorrente de mecanização, STAB. Açúcar, Álcool e Subprodutos, v.13, n.4, p.19-21, mar/abr. 1995.

ZARPELON, F.; STUPIELLO, J.P.; BACCARIM, L.M.; SILVA JÚNIOR, J.F.; PASQUOT, L.C.; BEZERRA, L.A. Controle Químico da Fabricação do Açúcar. Copersucar 1978 127p. 